Federal Reserve Bank of New York
Staff Reports

\title{
Evaluating Regulatory Reform: Banks' Cost of Capital and Lending
}

\author{
Anna Kovner \\ Peter Van Tassel \\ Staff Report No. 854 \\ June 2018 \\ Revised July 2020
}

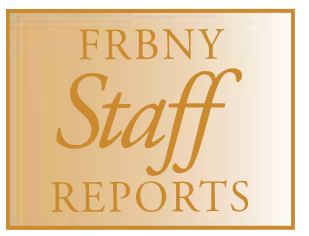

This paper presents preliminary findings and is being distributed to economists and other interested readers solely to stimulate discussion and elicit comments. The views expressed in this paper are those of the authors and do not necessarily reflect the position of the Federal Reserve Bank of New York or the Federal Reserve System. Any errors or omissions are the responsibility of the authors. 


\author{
Evaluating Regulatory Reform: Banks' Cost of Capital and Lending \\ Anna Kovner and Peter Van Tassel \\ Federal Reserve Bank of New York Staff Reports, no. 854 \\ June 2018; revised July 2020 \\ JEL classification: G12, G21, G28
}

\begin{abstract}
We examine the effects of regulatory changes on banks' cost of capital and lending. Since the passage of the Dodd-Frank Act, the value-weighted CAPM cost of capital for banks has averaged 10.5 percent and declined by more than 4 percent on a within-firm basis relative to financial crisis highs. This decrease was much greater for the largest banks subject to new regulation than for other banks and firms. Over a longer twenty-year horizon, we find that changes in the systematic risk of bank equity have real economic consequences: increases in banks' cost of capital are associated with tightening in credit supply and loan rates.
\end{abstract}

Key words: cost of capital, beta, bank regulation, Dodd-Frank act, banks

Kovner, Van Tassel: Federal Reserve Bank of New York (emails: anna.kovner@ny.frb.org, peter.vantassel@ny.frb.org). Any errors or omissions are the responsibility of the authors. The authors thank Charles Calomiris, Wilson Ervin, Stijn Van Nieuwerburgh, and Jeffrey Wurgler for discussing the paper. They also thank Malcolm Baker, Mark Carey, Douglas Diamond, Fernando Duarte, Victoria Ivashina, George Pennacchi, René Stulz, and seminar and conference participants at Chicago Booth, the Federal Reserve Bank of New York's Effects of Post-Crisis Banking Reforms Conference, the NBER Risks of Financial Institutions Conference, the Federal Reserve Bank of Boston, the Columbia/BPI Conference on Bank Regulation, Lending, and Growth, the 2019 annual meeting of the Central Bank Research Association (CEBRA), and the 19th Annual FDIC/JFSR Bank Research Conference for comments. In addition, they thank Davy Perlman, Anna Sanfilippo, and, particularly, Brandon Zborowski for outstanding research assistance. The views expressed in this paper are those of the authors and do not necessarily represent the position of the Federal Reserve Bank of New York or the Federal Reserve System.

To view the authors' disclosure statements, visit https://www.newyorkfed.org/research/staff_reports/sr854.html. 


\section{Introduction}

Bank regulations have changed dramatically over the past twenty years. Deregulation in the late 1990s repealed long-standing laws separating investment and commercial banking activities, allowing for the rise of larger and more complex global banking institutions. The financial crisis followed nearly a decade later prompting the Dodd-Frank Act (DFA) which intensified regulation particularly for the largest banks.

In this paper, we estimate the net effect of changing regulations on banks' cost of capital and link those changes to bank lending supply. We find that the banking industry's valueweighted CAPM cost of equity capital soared to over $15 \%$ during the financial crisis, but then declined by $4.5 \%$ relative to non-banks after the passage of the DFA. At the same time, banks' cost of capital has increased by 1-2\% relative to non-banks when the post-DFA period is compared to the Basel I period in the late 1990s. The magnitude of these changes is largethe financial crisis increase of $4.5 \%$ is nearly half of banks' CAPM cost of capital risk premium and more than a two-standard deviation move on a value-weighted basis. Time-series changes in equity betas drive these results. The findings are consistent with the interpretation that post-crisis regulations have lowered systematic risk in the banking industry with the cost of capital for the very largest banks moving back toward its average from the late 1990s prior to the passage of the Gramm-Leach-Bliley Act (GLB). These changes matter for the real economy - when banks' CAPM cost of capital falls, we find that banks expand credit supply and ease lending terms to borrowers.

We motivate the importance of studying banks' CAPM cost of capital by linking our cost of capital estimates to measures of credit supply, thus relating our analysis to the real effects of bank regulation. This distinguishes our paper from previous studies that focus on return predictability. For example, Baker and Wurgler (2015) show that the low-beta anomaly holds for banks and Dick-Nielsen et al. (2019) show that the implied cost of capital predicts 
bank stocks returns. Instead of predicting returns, we hypothesize that banks' CAPM cost of capital matters because the CAPM is used in practice by managers, investors, and lawyers (Graham and Harvey (2001), Berk and van Binsbergen (2016), Gilson et al. (2000)). Bank managers anecdotally use cost of capital estimates to allocate capital across divisions and bank CEOs cite the need to meet investors' return on equity targets as documented in annual reports and in bank executive compensation packages (Pennacchi and Santos 2018). This study is the first, to our knowledge, that establishes an empirical relationship between bank-level CAPM cost of capital estimates and bank lending supply.

We establish this link using confidential bank-level survey response data from the Senior Loan Officer Opinion Survey (SLOOS), a survey used to measure banks' willingness to lend that allows us to separate credit supply effects from demand (Lown and Morgan (2006), Hirtle (2009), Bassett et al. (2014), DeYoung et al. (2015)). We find that changes in the cost of capital are associated with changes in the supply and the pricing of credit. This result holds in aggregate for the panel of surveyed banks as well as in the cross section after controlling for changes in the risk-free rate, business cycle variation, and bank-level stock market returns to account for firm-specific shocks. When banks' CAPM cost of capital increases, bank managers tighten loan standards and increase loan spreads. Through this channel, regulations that change banks' CAPM cost of capital are passed through to the real economy.

Motivated by this new result, we study how banks' CAPM cost of capital has evolved over time in response to changing banking regulations and in comparison to other firms. Rather than focus on the impact of a single regulation, such as changes to capital standards, our approach acknowledges that banking regulations are endogenous and often change simultaneously. For example, consider the DFA. A priori, it is unclear what effect the DFA should have on the cost of capital for banks. The DFA increased effective capital requirements, 
established recovery and resolution frameworks, and introduced new liquidity requirements and leverage constraints, particularly for the largest banks. These different regulations have varied and potentially opposing effects on the cost of capital. All else equal, regulations that lower systematic bank risk by increasing capital and liquidity requirements should be expected to lower investors expected returns and thus banks' cost of capital. ${ }^{1}$ However, any rollback in perceived government guarantees may increase the cost of capital. Leverage requirements may reduce the systematic risk of bank equity by lowering the quantity of bank assets, but may also induce banks to increase asset risk by risk-shifting (Choi et al. 2019).

An additional contribution of this paper is to separate the net effect of regulatory changes from other factors impacting the cost of capital such as the level of short-term interest rates and the business cycle. We do this by estimating a variety of difference-in-differences specifications that compare changes in the cost of capital for banks to non-banks across periods separated by key dates in bank regulation. The regulatory periods are marked by the: Gramm-Leach-Bliley Act (GLB) (November 1999), Financial Crisis (July 2007), Supervisory Capital Assessment Program (SCAP) (May 2009), and Dodd-Frank Act (DFA) (July 2010). Figure 1 plots the monthly value-weighted CAPM cost of capital for banks over these time periods with dashed-horizontal lines at the means for each period. The regression analysis in the paper studies how the corresponding bank-level cost of capital estimates have changed over time in comparison to different groups of firms. Our comparative approach and twenty-year horizon expand on previous results from the literature. For example, Sarin and Summers (2016) focus more narrowly on pre- versus post-crisis changes for the banking industry in isolation, and thus miss how the period before the financial crisis was one in

\footnotetext{
${ }^{1}$ Even the impact of changes in capital requirements on the cost of equity is debated. On one hand, bankers argue that equity is more expensive than debt, so holding more equity increases the cost of capital with negative implications for growth and lending (see the discussion in Admati et al. (2014)). On the other hand, academics often contend that lower leverage should lower the cost of equity capital, leaving banks indifferent to their capital structure in the absence of tax advantages for debt and other frictions (Modigliani and Miller 1958).
} 
which the cost of capital was unusually low for banks.

We take several approaches to confirm that we are capturing changes to bank regulation and not other factors. First, we compare banks to non-banks and non-bank financial intermediaries. Non-bank financial intermediaries have similar business models to banks, but they are not directly affected by bank regulation. We find that the cost of capital declines more for banks between the SCAP and DFA periods than for non-banks or non-bank financial intermediaries (a differential decline for banks). Second, we compare banks more affected by regulation to those less affected (the top 20 banks by assets versus others). This analysis is particularly relevant when estimating changes around the passage of the DFA, as many DFA regulations specifically target the largest banks. We find that the largest banks' CAPM cost of capital has declined since the DFA by $3-4 \%$ relative to post-crisis highs and by $0-2 \%$ relative to the Basel I period in comparison to smaller banks and other firms. Third, we control for bank characteristics such as leverage, liquidity, and risk and find that observable characteristics do not explain the large changes that we observe in banks' cost of capital over time. Finally, we focus on only the largest US banks and study the staggered implementation of stress tests for banks with more than $\$ 50$ billion in assets (as in Flannery et al. (2017)). Similar to the other results, we find a differential decline in the CAPM cost of capital for the very largest, stress-tested banks from post-crisis highs. These results are also robust to the inclusion of controls for bank characteristics directly affected by regulation such as capital and liquidity. Overall, the results are consistent with the hypothesis that the net effect of DFA regulations was to lower the cost of capital for the largest banks, outweighing countervailing effects such as the potential for lower expectations of government insurance in the post-crisis period (Atkeson et al. 2018).

In addition to our baseline analysis using the CAPM, we confirm the robustness of our results by repeating our main regression specifications using alternative cost of capital mea- 
sures. The alternative measures include: multi-factor cost of capital estimates with Fama and French (1993) factors and interest rate factors from Schuermann and Stiroh (2006), CAPM cost of capital estimates with a time-varying equity risk premium (Cochrane 2011), log changes in CAPM betas that difference out the equity risk premium, and asset betas that de-lever bank stock returns (Baker and Wurgler 2015). ${ }^{2}$ Across measures, we consistently find a decrease in the cost of capital for the largest banks after the SCAP. By some measures, we also estimate that the largest banks' cost of capital has differentially fallen post-DFA relative to the levels that prevailed in the late 1990s.

Our approach provides a different perspective than papers that study the effect of individual regulations on bank stock returns. For example, Gandhi and Lustig (2015) and Kelly et al. (2016) examine implied government guarantees using size-sorted bank portfolios and equity option prices and find that too-big-to-fail subsidies decrease the cost of capital for the largest banks and for the financial sector. In contrast to these studies which use a portfolio-based approach, we use a panel-based approach that accounts for how changing bank business models and the changing composition of regulated banks affects the results. This allows us to control for banking industry consolidation around the financial crisis and the increase in non-interest income over the sample period. In addition, we contribute to the literature that studies how market measures such as Tobin's q are related to bank characteristics such as asset size, the value of intangibles, and the composition of bank assets (Minton et al. (2017), Calomiris and Nissim (2014), Huizinga and Laeven (2012)). Similar to prior studies, we find a significant relationship between the cost of capital and bank characteristics. The CAPM cost of capital is decreasing in core deposits and a proxy for the liquidity coverage ratio, and increasing in risk-weighted assets. However, even after including these

\footnotetext{
${ }^{2}$ The primary analysis focuses on the cost of equity capital for banks. Since these estimates are affected by leverage, we also study asset betas to understand how the systematic risk of banking assets has evolved, regardless of capital structure changes.
} 
controls, we still find a significant decline in the post-DFA cost of capital for the largest banks relative to the financial crisis.

\section{Estimating the cost of capital}

\subsection{CAPM cost of capital}

The cost of capital reflects the systematic risk of equity as well as the time value of money as captured by the risk-free rate. Empirically, we must rely on economic or statistical models to estimate the cost of capital. As a result, any test regarding the cost of capital is a joint test of the null hypothesis and the model that is used for estimation(Fama 1970). We use the CAPM for our baseline cost of capital analysis, but confirm our results are robust to other measures in Section 5. Our focus on the CAPM is motivated by its widespread use in practice. The relevance of this approach is further illustrated in Section 3 which finds a significant relationship between the CAPM cost of capital and bank lending supply.

We define our estimate of the CAPM cost of capital as,

$$
\mathrm{CAPM}_{i t}=\mathrm{Rf}_{t}+\beta_{i t} \cdot \mu_{r m r f}
$$

The first term is the risk-free rate $\mathrm{Rf}_{t}$. The second term is a time-varying CAPM beta $\beta_{i t}$ which is multiplied by an equity risk premium $\mu_{\text {rmrf }}$ that we assume is constant. ${ }^{3}$ We set the risk-free rate to the three-month Treasury bill rate and the equity risk premium

\footnotetext{
${ }^{3}$ Betas can be estimated precisely with high frequency data. In contrast, the equity risk premium is notoriously difficult to estimate. Even with a constant risk premium and log-normal returns, it would take over forty years to estimate the equity risk premium with a standard error of $3 \%$ from the time-series of returns (Merton 1980). This imprecision dominates the uncertainty in estimating expected returns in factor model settings (Fama and French 1997). Empirically, Welch and Goyal (2007) find that many models are unstable and under perform the historical mean at predicting returns out of sample. Based on these observations and for simplicity, we assume the equity risk premium is a constant equal to the historical mean in our baseline analysis. We relax this assumption in Section 5.
} 
to $8 \%$, the average CRSP value-weighted excess return from 1926 to 2017. The betas are estimated from one-year rolling regressions of firm-level daily excess returns onto market excess returns. Given our interest in how the cost of capital has varied over time, we prefer using daily data (252 observations per year) to deliver more precise and less biased estimates in comparison to slow moving estimates from monthly data (60 observations per five years). We compute betas using lagged data from the previous year. This ex-ante or lagged approach is meant to approximate real-time manager estimates of the cost of capital. The Appendix shows that similar results hold if betas are computed with weekly data, using the bettingagainst-beta approach from Frazzini and Pedersen (2014), or using optimal kernel-based estimates from Ang and Kristensen (2012) (Table A.3). Table 2 reports summary statistics for the cost of capital variables, value weighted by lagged market capitalization in Panel A. Banks (non-banks) value-weighted CAPM cost of capital averaged 11.5\% (10\%) over the last twenty-years. The risk-free rate averaged $2.2 \%$ over the corresponding sample period. Table 1 reports the definitions of the additional variables used in the paper including alternative cost of capital measures.

\subsection{Sample selection and definition of banks}

We use CRSP, Compustat, and regulatory data from call reports and Y-9C filings from March 1996 to December 2017 when estimating the cost of capital and for panel regressions with bank characteristics. We estimate the cost of capital for all CRSP firms with share codes 10 or 11 that are traded on the NYSE, NASDAQ, or AMEX. We filter observations from this dataset with missing cost of capital estimates or missing Compustat asset data as well as observations with share prices that are less than one dollar. The resulting sample includes a panel of 1,111,127 firm-month observations. ${ }^{4}$

\footnotetext{
${ }^{4}$ We merge quarterly Compustat data onto monthly CRSP data using the most recent observation that was announced prior to the start fo the month (based on RDQ date). In the event that firms issue multiple
} 
Defining banks within this sample is not straightforward. Limiting banks to depository institutions in SIC code 60 would exclude firms that became bank holding companies after the financial crisis in 2009. These firms are subject to financial regulation that is a key object of interest in the analysis. We therefore expand our definition to include both firms that are depository institutions (SIC code 6020-6036) as well as firms that have an RSSDID (the unique identifier assigned to financial institutions by the Federal Reserve) between the first and the last dates when regulatory assets from Y-9C filings are within $10 \%$ of total assets from Compustat. Firms that fulfill either of these criteria in month- $t$ are identified as banks by the binary variable Bank ${ }_{i t}$. We identify RSSDIDs using the FRBNY RSSDID-Permco crosswalk, which matches banks between Compustat and regulatory reports using name, city and state, and financial variables. ${ }^{5}$ Of the 11,961 firms in the sample, 1,415 firms are identified as banks throughout the sample while 34 firms are identified as banks for only part of the sample, including Metlife, Goldman Sachs, and Morgan Stanley. Because we include savings and loans in our definition as banks, and these firms only file call reports after 2012:Q1, there are 1,081 publicly traded banks with regulatory data, which is smaller than the total number of banks. In terms of sample size, there are 142,189 bank-month observations for which the CAPM cost of capital is estimated and 99,734 bank-month observations with bank characteristics from regulatory data. As a robustness check, the Appendix shows that

securities, we obtain unique firm-month observations by retaining the PERMCO-date pairs for the security (PERMNO) that has the largest market capitalization each month. Our use of the most recent quarterly accounting data from Compustat is similar to Hou et al. (2014) and Adrian et al. (2015) who form portfolios based on recent quarterly earnings data. This differs from Fama and French (1993) who form portfolios annually.

${ }^{5}$ SIC codes are obtained with descending priority from Compustat historical, Compustat header, CRSP historical, or CRSP header data depending on availability following the procedure described in Adrian et al. (2015). RSSDID-Permco matches are based on the FRBNY crosswalk as of 2016q4. This definition of banks differs from an entirely SIC code or NAICS driven approach. For example, 24 companies with SIC code 6099 (functions related to depository banking) are not coded as banks at some point in our sample. This subset includes some of the credit card companies that do not have an RSSDID or regulatory assets that match Compustat data (i.e. Mastercard, Visa). At the same time, 13 companies with an SIC code beginning with 62 are coded as banks in our analysis (i.e. Goldman Sachs, Morgan Stanley). We exclude AIG from the sample. 
similar results hold if we define banks as firms whose two-digit SIC code is 60 (depository institutions), indicating that the results are not driven by the definition of banks used in the baseline analysis (Table A.4).

\section{Banks' CAPM cost of capital and lending supply}

What motivates studying the CAPM cost of capital for banks? The asset pricing literature often emphasizes the low-risk anomaly and failure of the CAPM to predict stock market returns. Stocks with high (low) betas have historically earned lower (higher) returns than predicted by the CAPM. Frictions such as short-sale constraints, margin requirements, and differences in belief may drive a wedge between expected returns and systematic risk, suggesting that the CAPM is not useful for predicting returns (Black et al. (1972), Frazzini and Pedersen (2014), Baker and Wurgler (2015), Hong and Sraer (2016)). In contrast to these studies, we take interest in the CAPM not for return predictability, but because it provides a straightforward, single-factor measure of systematic risk that is commonly used in practice. A high CAPM beta today predicts a high CAPM beta in the future. ${ }^{6}$ Moreover, academic research and anecdotal evidence from bank supervisors indicate that investors and firms rely on the CAPM as a benchmark model (Graham and Harvey (2001), Berk and van Binsbergen (2016), Gilson et al. (2000)).

Given these observations, we hypothesize that the CAPM cost of capital matters for lending supply due to its widespread use by practitioners. If bank managers monitor and react to changes in the systematic riskiness of their stock price, there is a direct channel for CAPM betas to have real economic effects. In this section, consistent with our hypothesis, we document a significant relationship between the CAPM cost of capital and bank lending supply: when the CAPM cost of capital increases, banks tend to tighten credit supply. This

\footnotetext{
${ }^{6}$ This result holds within firm and in the cross-section. For example, see Table A.5 in the Appendix.
} 
result serves two purposes. First, it motivates further analysis of the CAPM cost of capital in the subsequent sections in the paper. Second, it contributes to the literature by being the first study, to our knowledge, that documents a link between the CAPM cost of capital and bank lending supply.

\subsection{Bank lending supply data}

The Federal Reserve conducts the Senior Loan Officer Opinion Survey (SLOOS) at a quarterly frequency covering questions about changes in the supply and demand for loans over the previous three months as reported in survey responses from senior loan officers at large banks. We make use of the SLOOS data because it offers a way to separate changes in lending supply from changes in lending demand (Lown and Morgan (2006)). This approach is superior to a simple estimation of the relationship between the cost of capital and loan balances or interest margins using bank holding company data, because the latter measures conflate the supply of bank lending with demand. ${ }^{7}$

As of 2017, the panel of reporting banks in the SLOOS included up to 80 large domestically chartered commercial banks that span all Federal Reserve Districts and up to 24 large U.S. branches and agencies of foreign banks. Our analysis focuses on survey questions related to bank lending supply, including questions on changes in lending standards and loan terms relative to the previous quarter. An example of one such question from the July 2018 SLOOS is:

Over the past three months, how have your bank's credit standards for approving applications for CËI loans or credit lines-other than those to be used to finance mergers and acquisitions - to large and middle-market firms and to small firms changed?

\footnotetext{
${ }^{7}$ We do not estimate a statistically significant relationship between the CAPM cost of capital and quarterly changes in loan balances or interest margins.
} 
Possible survey responses include: eased considerably, eased somewhat, remained basically unchanged, tightened somewhat, and tightened considerably. The questions are collected for loan standards to both large and middle-market firms (annual sales of $\$ 50$ million or more) as well as small firms.

We code these categorical response variables as $-2,-1,0,1$, and 2 in our regression analysis, with higher numbers indicating tighter credit standards. In addition to this broad question on credit standards, we also include in our analysis questions on the cost of credit lines, the spread of loan rates over banks' cost of funds, the premium charged on riskier loans, loan covenants, collateralization requirements, and the maximum size of credit lines. The summary statistics in Panel C of Table 2 show that these SLOOS survey responses are close to mean zero on average but exhibit significant variability with the standard deviation of the responses ranging from around .4 to .7 depending on the question.

\subsection{Banks' CAPM cost of capital and lending standards}

We begin by investigating the relationship between the CAPM cost of capital and bank lending supply graphically. Figure 2 plots the average SLOOS survey response for the quarterly change in credit standards to large and middle-market firms against the one-year change in banks' value-weighted CAPM risk premium. The changes in credit standards are $29 \%$ positively correlated with changes in the CAPM risk premium. This aggregate time-series correlation suggests a potential relationship, but the correlation is not statistically significant.

We thus exploit the cross-section of bank-level survey responses to increase the power of our test. The regression specification that we consider is:

$$
\operatorname{SLOOS}_{i t}=\alpha+\eta \cdot \Delta\left(\mathrm{CAPM}_{i t}-\mathrm{Rf}_{t}\right)+e_{i t} .
$$


To be specific, we regress the bank-level SLOOS survey response, a quarterly change, onto the one-year change in the bank-level CAPM risk premium. Similar results hold using sixmonth and two-year changes in the cost of capital and when we lag the change in the cost of capital by a quarter relative to the survey response. A positive coefficient on $\eta$ in these regressions indicates that bank managers are tightening credit standards or loan terms when their cost of capital is increasing.

Table 3 reports the results of the regression analysis. Across specifications and survey questions, we find a positive and often statistically significant relationship between changes in bank lending supply and changes in the CAPM cost of capital. The results indicate that banks tighten credit supply after their cost of capital increases. The first column in Panel A illustrates this result for the baseline regression described above for the broad question on credit standards for large and middle-market firms (Spd-LM). An increase in a bank's CAPM beta from 1 to 2 increases the cost of capital by $8 \%$ which translates into a $8 \times .024$ $=0.19$ higher survey response (specification 1), about one-fifth the magnitude of an increase from one category of response to another or about one-half of the standard deviation of the dependent variable which equals .46 as reported in the summary statistics table.

We want to be sure that we are not just capturing variation in the business cycle or the impact of idiosyncratic bank shocks. To account for this, the second column of Panel A adds one-year changes in the risk-free rate and the one-year bank level stock market returns as control variables (specification 2). Including bank-level stock market returns is a challenging test for omitted variable bias that allows us to capture the extent to which a negative shock from bad loans or poor profits may contribute to tighter lending standards. As expected, we estimate a negative and significant relationship between loan standards and both control variables. When interest rates decline or bank stock returns are low, lending standards are tighter. While adding these controls reduces the coefficient on the change in the CAPM cost 
of capital by half, it does not reverse the result. An increase in the CAPM cost of capital remains significantly and positively associated with tighter loan standards. Bank managers appear to tighten credit standards when the CAPM cost of capital increases, even after controlling for changes in the risk-free rate and for firm-level stock market returns.

As a final test, the third column illustrates that the results are robust to including quarterly fixed effects (specification 3), which is a more comprehensive control for any timevarying shocks that would affect bank lending supply. The time fixed effects increase the explanatory power from $16 \%$ to $26 \%$, indicating the importance of robust controls for the business cycle including the aggregate tightening of spreads during the financial crisis as seen in Figure 2. As before, the change in the cost of capital remains significant with a similar magnitude to the second specification. The subsequent columns report the same regressions where the dependent variable refers to credit standards for smaller borrowers (Std-S). The results are largely similar although of slightly smaller magnitudes (specifications 4-6).

\subsection{Banks' CAPM cost of capital and lending terms}

We next investigate how banks' CAPM cost of capital is related to different measures of lending terms. Each of the columns in Panels $\mathrm{B}$ and $\mathrm{C}$ has a different lending term as the dependent variable for large borrowers (Panel B) and small borrowers (Panel C). Since we found that quarterly fixed effects contribute substantial explanatory power, we include quarterly fixed effects in all of these specifications, similar to the third specification from Panel A. We find that increases in banks' cost of capital are associated with tightening in the supply and pricing of credit through all of the lending terms measured, with greater statistical and economic significance for larger borrowers. The estimated relationship is generally positive but not significant for smaller borrowers.

The cost of credit lines (CCL), spread of loan rates over a bank's cost of funds (Spd), and 
premiums charged on riskier loans $(\mathrm{RP})$ are perhaps the survey responses that most directly relate to the cost of capital. Indeed, we estimate the largest relationship between changes in the cost of capital and the response to these questions. In addition to these impacts on loan prices, we also find that banks tighten the maximum size of credit lines and loan covenants when their cost of capital increases, thereby reducing credit supply. The results for collateral requirements are similar but not significant.

The varied findings highlight the rich nature of the SLOOS data. Rather than being restricted to only study the quantity and pricing of loans through quarterly changes in loan balances or interest margins in call report data, the SLOOS allows us to investigate the provision of credit along multiple dimensions from the perspective of senior loan officers who are responsible for allocating credit in the economy. Building on the prior literature such as Frank and Shen (2016) that has documented a negative relationship between the cost of capital and investment for non-financials, our results provide new evidence on the importance of the CAPM cost of capital for banks. Banks tighten the supply and pricing of credit in the economy when their CAPM cost of capital increases.

\section{Banks' CAPM cost of capital over time}

The previous section establishes a link between the CAPM cost of capital for banks and lending supply. Motivated by this finding, we now investigate the relationship between regulation and the cost of capital. For example, to the extent that changes in regulation lower banks' cost of capital, regulation may be passed through to the real economy through the bank lending channel studied in the previous section.

Identifying the impact of regulation on banks' cost of capital is, however, a challenging empirical problem. Bank regulations are endogenous and often change simultaneously. 
Acknowledging this, we attempt to estimate the net effect of regulation around periods of significant regulatory change and also separate periods when the regime shifted from 1996 to 2017 using a difference-in-differences approach. The time periods we study are:

1. Pre-period: Basel I Regime (March 1996 to October 1999)

2. GLB: The Gramm-Leach-Bliley Act (November 1999 to June 2007)

3. Crisis: The Financial Crisis (July 2007 to April 2009)

4. SCAP: The Supervisory Capital Assessment Program (May 2009 to June 2010)

5. Dodd-Frank: The Dodd-Frank Act (July 2010 to December 2017)

The break points for the GLB and Dodd-Frank periods are the months of the passage of the relevant banking law. For the financial crisis we define the start date as July 2007 and separate the period after the release of the SCAP test results. The Appendix shows that similar qualitative results hold if we combine the Crisis and SCAP periods into a single Crisis period (Table A.6). Results are also similar if we vary the time periods within a few months to account for anticipation of the legislation or to allow for a different start date for the financial crisis. ${ }^{8}$

We compare changes in the CAPM cost of capital for banks to changes for a range of control groups of firms around these regulatory time periods. In particular, we compare

\footnotetext{
${ }^{8}$ The definition for the start of the financial crisis and decision to separate the SCAP period are motivated by the paper's focus on understanding how regime shifts impact the cost of capital for banks. While the NBER recession corresponding to the financial crisis is dated from December 2007 to June 2009, there was significant turmoil in funding and credit markets starting in the summer of 2007 that affected the largest banks. For example, in July 2007, Bear Stearns Asset Management revealed the collapse of two of its structured credit hedge funds. In August 2007, credit default swap rates for hedge fund prime brokers increased (Mitchell and Pulvino 2012), equity markets suffered the quant quake (Khandani and Lo 2011), the TED spread widened by more than 150 basis points, and the BBB credit spread widened by more than 50 basis points. Based on these observations, we define the start of the financial crisis as July 2007, which is similar timing to studies of banks during the crisis such as Kelly et al. (2016). In addition, we define the end of the crisis as coinciding with the release of SCAP test results, an event that marks the start of providing more information to the market about the capital and solvency of systematically important firms through the use of forward-looking stress tests (Flannery et al. 2017).
} 
banks to non-banks and non-bank financial intermediaries. We compare the top 20 banks by assets to other banks. We study banks in isolation and control for bank characteristics. Finally, we consider only the largest banks and study the staggered implementation of stress tests. The results can be interpreted in two ways. First, they provide a descriptive analysis of how banks' cost of capital has evolved over time in relation to different firms. Second, to the extent that banks' cost of capital exhibits large changes relative to other firms across periods with significant changes in banking regulation, the results are suggestive that regulation is contributing to the differential change for banks.

Determining that this differential effect is caused by changes to bank regulation requires a control group that provides an accurate counterfactual for banks' cost of capital in the absence of the treatment effect. To the extent that the break points in the analysis are not associated with other business model changes for banks, the simple difference across periods from Figure 1 is suggestive that regulation is playing a role. For the differencein-differences estimation, empirical studies often investigate the plausibility of a particular control group by plotting the outcome variable in the pre-period for both the treatment and control groups to test for parallel trends. In our settting, this is complicated by the fact that we have multiple changes in regulation and regime shifts over the past twenty years. The period before Basel 1 (pre-period) serves as the baseline period to which the key differencein-differences regression coefficients are compared, and we see parallel trends in many of the comparison sets in that pre-period, with the cleanest comparison with respect to non-bank financials. However, the parallel trends assumption is rejected for some of the other periods and control groups. Specifically, prior to the passage of Dodd-Frank, it was precisely the divergence in the systemic risk of banks relative to other firms that was in part the cause of the regulation. ${ }^{9}$

\footnotetext{
${ }^{9}$ The Appendix provides more information about the cost of capital for banks compared to different control groups over the full sample period and tests for parallel trends around each of the regulatory time
} 


\subsection{Banks versus non-banks}

We begin by estimating the following specification to see how banks' cost of capital has changed over time in comparison to non-banks:

$$
\begin{aligned}
& \mathrm{CAPM}_{i t}-\mathrm{Rf}_{t}=\alpha+\beta_{1} \mathrm{GLB}_{t}+\beta_{2} \text { Crisis }_{t}+\beta_{3} \mathrm{SCAP}_{t}+\beta_{4} \text { Dodd-Frank }_{t}+\rho \text { Bank }_{i t} \\
& \quad+\delta_{1} \text { Bank }_{i t} \mathrm{GLB}_{t}+\delta_{2} \text { Bank }_{i t} \text { Crisis }_{t}+\delta_{3} \text { Bank }_{i t} \mathrm{SCAP}_{t}+\delta_{4} \text { Bank }_{i t} \text { Dodd-Frank }_{t}+e_{i t} .
\end{aligned}
$$

The dependent variable is the bank-level CAPM risk premium, $\mathrm{CAPM}_{i t}-\mathrm{Rf}_{t}$. The binary variables $\mathrm{GLB}_{t}$, Crisis $_{t}, \mathrm{SCAP}_{t}$, and Dodd-Frank $t$ are equal to one during the time periods defined above. The omitted pre-period begins twenty years ago in 1996 and is characterized by the Basel I regulatory regime ("pre-period"). The bank indicator Bank it $_{i}$ and interaction terms with the time period indicators allow the cost of capital to change differently for banks and non-banks over time. When we estimate $\delta_{i}$ that are different from 0 , the change to the cost of capital for banks in period $i$ relative to the Basel I period are different from the corresponding change for non-banks. We report value-weighted and equal-weighted results to understand how the cost of capital is changing for larger banks and for the average bank. Generally, we focus on the value-weighted approach as this provides a metric of how the cost of capital has changed for the industry in aggregate. The sample is monthly from March 1996 to December 2017 with standard errors clustered by firm and by month. ${ }^{10}$

Table 4 reports the results. Starting with the value-weighted regressions, the first column (1) shows that the cost of capital has been roughly stable over time when all firms are pooled together. This result is expected and reflects a summing up constraint. To the extent that

period breaks. The results indicate that the best identified comparisons are those between banks and nonbank financials and between the very largest stress-tested banks and other large banks.

${ }^{10}$ The value weights are proportional to lagged market capitalization and are normalized each month by the total lagged market capitalization of all firms in the panel. Results are similar if the analysis incorporates earlier data (back through 1986), however, we focus on the more recent time period to have consistency in the regulatory data, which becomes available for all fields used in the analysis starting in the first quarter of 1996. 
our regressions capture the entire market, the value-weighted average CAPM beta should be equal to one at each point in time with a corresponding risk premium of $8 \%$ based on our definition of the cost of capital. ${ }^{11}$ The second column (2) estimates a difference-indifferences regression by adding the bank indicator and interaction coefficients. While the summary statistics table indicates that banks have a higher cost of capital than non-banks on average, the regression shows how this premium changes over time. In the GLB period, the cost of capital for banks is $1 \%$ lower than that of non-banks as indicated by the significant Bank x GLB coefficient. This result is surprising because the GLB is often interpreted as being deregulatory and therefore related to an increase in the systematic risk of banks. The cost of capital then increases significantly for banks relative to non-banks during the Crisis and SCAP periods. In the Dodd-Frank period, the differential cost of capital for banks falls by approximately $4.5 \%$ from the Bank x SCAP coefficient of around $6.5 \%$ to the Bank $\mathrm{x}$ Dodd-Frank coefficient of $1.9 \%$. The results are consistent with the interpretation that the net effect of Dodd-Frank was to reduce the systematic risk of banks, with reforms like increased capital and liquidity requirements more than offsetting opposing effects such as reductions in too-big-to fail guarantees, and is consistent with post-financial crisis regulation moving the systematic risk of banks back towards the pre-deregulation period of the late 1990s, but still remaining elevated relative to the Basel I period.

The third column (3) adds firm fixed effects $\alpha_{i}$ that replace the constant $\alpha$. The changing panel would otherwise present a concern around the financial crisis as a number of very large banks and broker dealers exit the sample due to mergers or bankruptcy while a number of very large broker dealers and credit card companies become bank holding companies. Beyond the crisis, there are also changes in the panel throughout the sample due to private firms

\footnotetext{
${ }^{11}$ The data filters such as requiring a year of lagged data to compute CAPM betas and the entry and exit of firms may drive a small difference between the value-weighted average beta and one, but we see from column (1) that this difference is not statistically significant, consistent with the notion that we are capturing the entire market in the regressions.
} 
entering by going public and public firms exiting as a result of mergers and acquisitions or bankruptcy. We find that the changing panel composition is not driving the broad results. In the GLB period, there is still a differential decline in banks within-firm cost of capital, although now the decline is not significant. After the Dodd-Frank period, the within-firm cost of capital for banks continues to fall by around $4.5 \%$ relative to non-banks. At the same time, banks' within-firm cost of capital is around $2.5 \%$ higher than that of non-banks relative to the Basel I period, which is somewhat higher than in column (2). This could be consistent with an increase in the perceived riskiness of the industry due to a reduced probability of government assistance or with a re-evaluation of the systematic risk of the banking industry in general.

The fourth column (4) compares banks to non-bank financial intermediaries. The estimated coefficient on Bank x SCAP falls by almost half, but there is still a differential decline in banks' cost of capital in the Dodd-Frank period. The difference between the Bank $\mathrm{x}$ SCAP coefficient of 3.75 and Bank x Dodd-Frank coefficient of 1.48 is economically and statistically significant, indicating that banks' cost of capital declined by around $2.25 \%$ relative to non-bank financials after the DFA. This differential is large - nearly $25 \%$ of the average CAPM risk premium for banks and more than a one-standard deviation move relative to banks monthly value-weighted cost of capital. ${ }^{12}$ This result adds weight to the notion that the net effect of the DFA was to reduce the systematic risk of banks, as we obtain a similar qualitative finding for a different control group of firms whose business model is more closely related to that of banks. There is, however, still a $1.5 \%$ increased cost of capital for banks relative to non-bank financials in the Dodd-Frank period compared to the Basel I period.

The subsequent columns (5-8) repeat these regressions on an equal-weighted basis. To the extent that different banks serve different borrowers, it is important to understand how

\footnotetext{
${ }^{12}$ The standard deviation of the monthly value-weighted CAPM cost of capital for banks and non-bank financials is $2.2 \%$ and $1.1 \%$ respectively.
} 
banks' cost of capital changes not just for the industry in aggregate, but also for the average bank. In contrast to the value-weighted results, the change in banks' cost of capital after the financial crisis is much smaller when the results are equal-weighted. In fact, in the cross section, the cost of capital is lower in the Dodd-Frank period relative to the Basel I period for the average bank (specification 6). However, looking within firm, the sign flips and we see a differential increase of around $1.75 \%$ relative to non-banks (specification 7 ) and $1.6 \%$ relative to non-bank financials (specification 8) in comparison to the Basel I period. Overall these results are consistent with the decline in banks' cost of capital post-crisis arising from changes to the cost of capital for the largest banks. We explore this question in more detail in the next section.

\subsection{Top banks versus non-Top banks}

While the previous regressions highlight the change in the cost of capital for banks relative to other firms, they potentially conflate the impact of changing regulation with other sources of time variation in the cost of capital. The cost of capital may be different for the very largest firms in an industry compared to other firms, for example, as a result of differences in systematic risk, market beliefs about implicit government support, or an association between firm size and market power. ${ }^{13}$ In the bond market, Hale and Santos (2014) find that larger firms borrowing from bond-financed banks pay lower spreads on their loans than smaller firms borrowing from deposit-financed banks. Further, the relationship between size and expected returns can change over time. To better understand the impact of regulation targeted at the largest banks, we thus need to ensure that we difference out changes over time in the cost of capital by size so we do not attribute those changes to changes in bank regulation.

\footnotetext{
${ }^{13}$ While large banks may be better diversified, diversification may not result in reduced risk to the extent that it facilitates greater leverage or riskier lending (Demsetz and Strahan 1997). As a result, large and diversified banks may still be exposed to the economy in general, resulting in high systematic risk which is the only risk priced in the CAPM.
} 
To build a time series of large banks, we look more closely at the subset of banks most affected by post financial crisis regulatory changes: banks with more than $\$ 50$ billion in assets. Banks with more than $\$ 50$ billion in assets are approximately the twenty largest banks in the US at the end of the sample, so we create a dummy variable ("Top") to capture the largest twenty firms by total assets within different industries at each point in time. We define industries by SIC code using the twelve industry portfolios on Ken French's website and split financials into banks and non-bank financials using the definition of banks described earlier in the paper. This gives us a measure that we can use over a long time series and across industries.

We repeat the analysis from equation 3 adding interactions between our coefficients of interest and the Top dummy variable. We also begin to control for firm characteristics by narrowing in on the effect of changing leverage. To compute leverage across financial and non-financial firms, we define the variable Leverage $_{i t}$ as total debt divided by the market value of assets (total debt plus the market value of equity) using Compustat's total debt measure, adding deposits to the total debt measure for banks. The regression specification is:

$$
\begin{aligned}
& \mathrm{CAPM}_{i t}-\mathrm{Rf}_{t}=\alpha+\beta_{1} \mathrm{GLB}_{t}+\beta_{2} \mathrm{Crisis}_{t}+\beta_{3} \mathrm{SCAP}_{t}+\beta_{4} \text { Dodd-Frank }_{t}+\rho \text { Bank }_{i t}+\eta \mathrm{Top}_{i t} \\
& +\nu \text { Bank }_{i t} \operatorname{Top}_{i t}+\delta_{1} \text { Bank }_{i t} \mathrm{GLB}_{t}+\delta_{2} \text { Bank }_{i t} \text { Crisis }_{t}+\delta_{3} \text { Bank }_{i t} \mathrm{SCAP}_{t}+\delta_{4} \text { Bank }_{i t} \text { Dodd-Frank }_{t} \\
& +\chi_{1} \operatorname{Top}_{i t} \mathrm{GLB}_{t}+\chi_{2} \operatorname{Top}_{i t} \text { Crisis }_{t}+\chi_{3} \operatorname{Top}_{i t} \mathrm{SCAP}_{t}+\chi_{4} \operatorname{Top}_{i t} \text { Dodd-Frank }_{t}+\gamma_{1} \text { Bank }_{i t} \operatorname{Top}_{i t} \mathrm{GLB}_{t} \\
& +\gamma_{2} \text { Bank }_{i t} \operatorname{Top}_{i t} \text { Crisis }_{t}+\gamma_{3} \operatorname{Bank}_{i t} \operatorname{Top}_{i t} \operatorname{SCAP}_{t}+\gamma_{4} \text { Bank }_{i t} \operatorname{Top}_{i t} \text { Dodd-Frank }_{t}+\phi \text { Leverage }_{i t}+e_{i t} \text {. }
\end{aligned}
$$

As before, we consider specifications with and without firm fixed effects, regressions that compare banks to all non-banks and only non-bank financials, and we report value-weighted and equal-weighted results.

Table 5 summarizes the results of these triple difference-in-differences regressions. Consistent with our hypothesis that firm size matters, the first column (1) indicates that the cost of capital is about $2 \%$ higher for Top banks compared to other banks on average (Top 
coefficient of $-1.46+$ Bank x Top coefficient of 3.41). The remaining specifications add interactions with the Top indicator to understand how the cost of capital for Top firms has evolved as regulation has changed. The second (2) and third (3) specifications show that Top firms cost of capital has declined in each period since the GLB period by around $1 \%$ to $2 \%$. This decline occurs across industries and holds both cross-sectionally and within firm. Focusing on the Top banks, the Bank x Top x Dodd-Frank coefficient is either significantly negative or insignificant across specifications. This result indicates that the Top banks most targeted by regulation have experienced a differential decline in their cost of capital during the Dodd-Frank period as compared to the Basel I period of the late 1990s, at least by some measures.

Figure 3 illustrates the regression results graphically by plotting the value-weighted difference in the cost of capital for banks versus non-banks and for Top banks versus non-Top banks relative to Top non-banks versus non-Top non-banks over time. The dashed-horizontal lines indicate the means for each period. The changes in these means relative to the Basel I period are similar to the $\delta$ and $\gamma$ coefficients in the value-weighted regressions without firm fixed effects. For example, the plot reveals an increased period mean from the Basel I period to the Dodd-Frank period for banks versus non-banks but little to no change for Top banks in the triple difference specification. This result is consistent with the positive and significant Bank x Dodd-Frank coefficient and the negative and insignificant Bank x Top x Dodd-Frank coefficient in specification (2) in Tables 4 and 5. Moreover, the plot illustrates the large decline in banks' and Top banks' cost of capital across the SCAP and Dodd-Frank periods.

In the regressions, the difference between the Bank x Top x Dodd-Frank and Bank x Top x SCAP coefficients is consistently negative and statistically significant, meaning that the cost of capital for the very largest banks has fallen between the SCAP and Dodd-Frank periods 
both in the cross-section and on a within firm basis. The exception is specification (4) which compares banks to non-bank financials. In this case, we estimate the cost of capital for the very largest banks to be differentially and significantly lower by $2.4 \%$ compared to the late 1990s, with a decline of $1.2 \%$ since the SCAP period that is negative but not statistically significant. The fifth specification (5) controls for leverage and finds little impact on the results compared to the third specification (3). The Top banks cost of capital continues to exhibit a differential decline of around $4 \%$ from the SCAP to the Dodd-Frank period in specification (5), showing that changes in leverage are not driving the results. In addition, specifications (7) and (8) show that similar results continue to hold for the Top banks in equal-weighted regressions.

\subsection{Role of bank characteristics}

The decline in the largest banks' CAPM cost of capital since the Dodd-Frank Act is not explained by changes in the cost of capital for non-banks, non-bank financials, or non-Top banks. But what about changes in bank characteristics? Changes in regulation may impact banks' cost of capital by changing bank risk, capital, liquidity, and business models. At the same time, bank managers may change their firm's characteristics in response to time-varying investment opportunities or in response to changes in the market's evaluation of bank risks, thereby impacting their cost of capital.

We estimate the following regression to study whether changes in bank characteristics can explain changes in banks' cost of capital over time:

$$
\mathrm{CAPM}_{i t}-\mathrm{Rf}_{t}=\alpha+\beta_{1} \mathrm{GLB}_{t}+\beta_{2} \mathrm{Crisis}_{t}+\beta_{3} \mathrm{SCAP}_{t}+\beta_{4} \text { Dodd-Frank }_{t}+\theta \cdot X_{i t}+e_{i t} .
$$

In this analysis, we focus on the universe of regulated banks for which we have detailed data 
on firm characteristics from regulatory reports. We estimate the regression on a bank-only panel for which the bank characteristics denoted as $X_{i t}$ are available as control variables. The regressions allow us to test whether aggregate or cross-sectional changes in bank characteristics are related to the cost of capital. For example, this allows us to test whether decreases in leverage after the financial crisis are associated with a lower CAPM cost of capital. Table 1 defines the bank characteristic variables $X_{i t}$ that are used in the regression analysis. We proxy for capital and liquidity with the Tier 1 capital ratio, core deposits, and a measure of liquidity coverage. ${ }^{14}$ We account for asset composition and risk by including the proportion of non-interest income to total income and the ratio of risk-weighted assets to total assets. The Appendix includes specifications with additional variables including the components of risk-weighted assets such as cash-equivalent assets, loans, trading assets, commitments and derivatives to total assets.

Table 2 reports value-weighted summary statistics for the bank characteristic variables in percentage units. All balance sheet items are measured as of the most recent quarter and are winsorized at the 1st and 99th percentiles to mitigate the impact of outliers in the regression analysis. Table A.2 in the Appendix reports value-weighted averages for the different variables over time. Following the passage of the Dodd-Frank Act, capital ratios, core deposits, and liquidity coverage are higher while risk-weighted assets, loans, and commitments are lower. Other ratios peaked in the Crisis and SCAP periods such as derivatives and non-interest income share.

Table 6 reports the regression results. The specifications are value-weighted to focus on large banks and include firm fixed effects to control for changes in the composition of the panel by looking at within firm variation. The first column (1) reports how the value-weighted

\footnotetext{
${ }^{14}$ The core deposit measure includes demand deposits, other noninterest-bearing deposits, and most interest-bearing deposits following Calomiris and Nissim (2014). The liquidity coverage measure is equal to 100 minus the liquidity stress ratio from Choi et al. (2019). A higher liquidity coverage measure indicates that a bank is more liquid and less exposed to liquidity risk stemming from maturity transformation.
} 
CAPM cost of capital has evolved over time for the panel of regulated banks. Similar to the baseline difference-in-difference results from Table 4 that include all bank and non-bank observations, we continue to find a large and significant decline in the value-weighted CAPM cost of capital for the panel of regulated banks between the SCAP and Dodd-Frank periods by around 5\% and a higher cost of capital in the Dodd-Frank period compared to the Basel I period by around $1.5 \%$.

The following columns (2-6) add each of the characteristic variables as individual controls. The final column (7) adds all of the characteristic variables together. On average, we find that bank characteristics do little to explain the way in which banks' aggregate cost of capital has changed over time. Even in the final specification (7) that includes all of the characteristics, the estimated coefficients on the different time periods are similar and not significantly different from the first specification (1) that doesn't include any of the controls. While the time period coefficients are roughly stable, we do estimate significant effects for some of the controls. In particular, we find that the CAPM cost of capital is decreasing in core deposits and liquidity coverage, and increasing in risk-weighted assets. According to the estimated coefficients, an increase in core deposits and liquidity coverage by $10 \%$ is associated with a lower cost of capital by 40 and 30 basis points respectively, while an increase in risk-weighted assets by $10 \%$ is associated with a higher cost of capital by 30 basis points. These magnitudes are somewhat large, but they cannot explain the nearly $4.5 \%$ change in the cost of capital for banks between the SCAP and Dodd-Frank periods.

The Appendix extends this analysis to the Top banks and to key components of riskweighted assets (Tables A.7 and A.8). Looking within the components of RWA, we find that banks' cost of capital is negatively associated with cash equivalents, loans, and loan commitments. The finding for cash equivalents is similar to the negative association between the cost of capital and core deposits. The multivariate specification with all of the RWA 
components indicates that a $10 \%$ increase in cash equivalents and loans is associated with a $1.5 \%$ and $1 \%$ decline in the cost of capital, a somewhat larger magnitude than for core deposits. Nonetheless, there is still a decline of around $4.5 \%$ in banks' cost of capital between the SCAP and Dodd-Frank periods. Similarly, we find that bank characteristics do little to explain the changes in Top banks cost of capital over time. Overall, the results suggest that changes in banks' cost of capital are not explained by changes in observable bank characteristics throughout the sample period.

\subsection{Effect of stress testing}

While it is hard to attribute changes in the cost of capital to particular regulations because so many regulations were changed at the same time for the same set of firms, we attempt to take advantage of the staggered implementation of stress testing on banks with more than $\$ 50$ billion in assets to understand how a particular regulatory change, stress testing, may have affected the cost of capital for stress-tested banks. To do this, we adopt the identification approach of Flannery et al. (2017) and estimate:

$$
\begin{aligned}
& \mathrm{CAPM}_{i t}-\mathrm{Rf}_{t}=\alpha+\beta_{1} \mathrm{GLB}_{t}+\beta_{2} \mathrm{Crisis}_{t}+\beta_{3} \mathrm{SCAP}_{t}+\beta_{4} \mathrm{PreCCAR}_{t}+\beta_{5} \text { PostCCAR }_{t}
\end{aligned}
$$

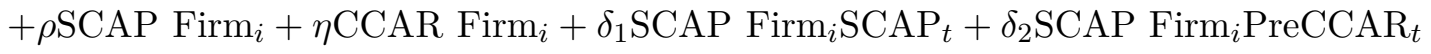

$$
\begin{aligned}
& +\delta_{3} \mathrm{SCAP} \mathrm{Firm}_{i} \text { Post CCAR }_{t}+\gamma \mathrm{CCAR} \mathrm{Firm}_{i} \mathrm{PostCCAR}_{t}+\theta \cdot X_{i t}+e_{i, t}
\end{aligned}
$$

As in Flannery et al. (2017), we limit the panel to the top 90 banks by assets each month to ensure that our comparison group of non-stress-tested banks is closer to the group of stress-tested banks. ${ }^{15}$ We split the stress-tested banks into two groups based on the timing

\footnotetext{
${ }^{15}$ Note that not all firms that are stress tested are publicly traded - we exclude from the analysis the banks with foreign parents, and Ally and Citizens join the panel only after IPO. Because of its bankruptcy and subsequent reorganization, we exclude CIT from the panel entirely. If included, it would be the only bank in its category, since it was added to stress testing in 2016, and it would be in the comparison, non-stress tested group before that time. Similarly, we exclude Metlife from the panel entirely due to its subsequent debanking. Two US stress tested firms were not public for the entire sample. The first observation for Ally (SCAP) is April 2015 and the first observation for Citizens (CCAR) is September 2015.
} 
of their exposure to Federal Reserve stress testing. The first banks exposed to stress testing are captured by the binary variable SCAP Firm $i$ which is equal to 1 for the largest BHCs that were initially included in stress tests beginning with the SCAP in 2009. The next banks exposed to stress testing are captured by the binary variable CCAR Firm C $_{i}$ which is equal to 1 for the banks subjected to Comprehensive Capital Analysis and Review (CCAR) stress tests starting in 2014 ("CCAR 2014 Addition"). The regulatory time periods are also changed to accommodate the phased implementation of stress testing by splitting the Dodd-Frank period into two sub-periods separated by the expansion of firms subject to stress testing:

1. Pre-CCAR ${ }_{t}$ : Passage of the Dodd-Frank Act when the 18 firms $\left(\mathrm{SCAP} \mathrm{Firm}_{i}\right)$ are subject to stress testing and associated disclosure (July 2010 to August 2013)

2. Post-CCAR : Addition of 7 firms $($ CCAR Firm $i)$ to stress testing and associated disclosure (September 2013 to December 2017)

We include bank characteristics $X_{i t}$ as control variables in some specifications, similar to the previous section.

Table 7 reports the regression results. On average, the CAPM cost of capital for the large banks in the panel increases relative to the Basel I period (specification 1). The cost of capital is $7 \%$ higher in the SCAP period, $4 \%$ higher in the Pre-CCAR period, and 3.5\% higher in the Post-CCAR period relative to the Basel I period. Figure 4 illustrates these results by plotting the equal-weighted cost of capital for the SCAP, CCAR, and other banks in the top 90 by asset size. In addition, the plot indicates that the cost of capital for SCAP firms experiences the largest increase during the financial crisis and subsequent decline in the post-Dodd-Frank period.

The regressions in the subsequent columns formalize this result. Specifications 2-4 add interaction terms to allow for a different cost of capital for the SCAP firms after 2009 and for 
the CCAR firms in the post-CCAR period. We find that SCAP firm's CAPM cost of capital differentially increased by around $2 \%$ during the SCAP period and then declined by around $1.2 \%$ in the post-CCAR period relative to the other large banks in the panel (specification 2). Within-firm, there is more than a 3\% decline in the cost of capital for SCAP firms between the SCAP and post-CCAR periods that is significant at the $1 \%$ level and robust to including bank characteristics as control variables (specifications 3-4). The final columns show that the results are not specific to the CAPM, but also hold using the Fama-French three-factor model (FF3) as an alternative cost of capital measure that will be described in more detail in the upcoming section (specifications 5-8).

Overall, the results indicate that the largest, stress-tested banks (SCAP Firms) have experienced the greatest reduction in their cost of capital since the introduction of stress testing. On one hand, this result can be interpreted as evidence in favor of the hypothesis that stress testing has reduced the systematic risk of the very largest firms. On the other hand, it is challenging to distinguish this hypothesis from the alternative explanation that the decline reflects other regulations to which only these very largest firms are subject that were implemented with similar timing to that of stress testing. While we think the staggered introduction of firms to stress testing contributes identifying power to the approach, we also note that it is difficult to identify changes over shorter windows than those considered in this analysis, since the betas underlying our cost of capital measures require time to estimate.

\section{Alternative cost of capital estimates}

One contribution of this paper is to establish an empirical relationship between the CAPM cost of capital and bank lending supply. We find that banks tend to tighten credit supply when their CAPM cost of capital increases. Motivated by this result, we study how the 
systematic risk of banks has evolved over time through the lens of the CAPM. Compared to other groups of firms, we find that the largest banks have experienced a significant decline in their CAPM cost of capital between the SCAP and Dodd-Frank periods.

Do similar results hold for other cost of capital measures? Empirically, there are a myriad of approaches for measuring the cost of capital. In this section, we investigate the robustness of our findings by estimating several alternative measures of the cost of capital - Table 8 repeats the key difference-in-differences specifications for banks and Top banks for alternative cost of capital measures including three-factor estimates from the Fama and French (1993) model, five-factor estimates that incorporate additional interest rate and term spread factors, CAPM estimates with a time-varying equity risk premium, log CAPM betas that difference out the equity risk premium, and asset betas from the Merton (1974) model that account for leverage.

The alternative measures primarily focus on the cost of equity capital which is consistent with bank manager's focus on ROE (Pennacchi and Santos (2018)). For example, if banks are managing a net interest margin spread, the cost of debt may not be a relevant metric for lending or investment decisions. However, given that banks are heavily financed with debt and deposits, an equity based measure may not capture all aspects of the average or marginal financing costs for a bank. To take this into account, Table 9 considers the weighted average cost of capital (WACC) as another measure to account for leverage and the after-tax cost of debt.

Across the various estimates we consistently find a significant decrease in the cost of equity capital for the largest banks between the SCAP and Dodd-Frank periods. Figure 5 summarizes these results by plotting the value-weighted alternative cost of capital measures alongside our estimates of asset betas and market leverage for the banking sector. In the WACC regressions, we find a significant decline in banks' weighted average cost of capital 
since the passage of the Dodd-Frank Act, but not an additional decline for the Top banks.

\subsection{Multifactor cost of capital estimates}

The Fama and French (1993) three-factor model (FF3) delivers cost of capital estimates that account for the variation in expected returns for small versus big firms and for value versus growth firms. As before, we define the FF3 cost of capital as the sum of time-varying betas multiplied by constant factor risk premiums. We set the factor risk premiums equal to the average excess returns for the tradeable factors from 1926 to 2017 which are equal to $8 \%, 4.6 \%$, and $2.5 \%$ in annualized units for the market, value, and size factors respectively. The average beta or loading on these factors for banks over the last twenty years has been $1.17(0.54), 0.85(0.43),-0.11(0.41)$ respectively versus $1.17(0.55)$ for the CAPM on a value-weighted (equal-weighted) basis.

Columns (1) and (2) of Table 8 repeat the value-weighted difference-in-differences regressions with firm fixed effects from Tables 4 and 5 for banks and Top banks using the FF3-Rf cost of capital. Compared to the previous results, the FF3 model indicates that banks' cost of capital diverged the most from non-banks in the GLB period immediately preceding the financial crisis, when value factor betas were declining and banks were trading more like growth firms (column 1). Similar to before, the Top banks continue to exhibit a large and significant decline in their FF3 cost of capital between the SCAP and Dodd-Frank periods (column 2). In fact, the Bank x Top x Dodd-Frank coefficient is negative and significant, indicating that the FF3 cost of capital has differentially declined for the largest banks by as much as $3 \%$ relative to the Basel I period. This result is stronger than the Top regressions for the CAPM which also feature negative coefficients on Bank x Top x Dodd-Frank but with magnitudes that are smaller and less significant.

Beyond size and value, if there are other factors or systematic risk exposures that affect 
the cost of capital differently for bank versus non-banks, we would like to control for those factors in our analysis. One such factor may be changes in interest rates, as maturity transformation and interest rate risk management are key aspects of bank business models, but may be less important for non-bank firms. To that end, we form a five-factor model (IR) that adds a short-term interest rate factor and a yield curve slope factor to the FF3 model. Columns (3) and (4) of Table 8 report the results. To maintain consistency with our prior analysis, we compute betas from multivariate time-series regressions using tradeable interest rate factors that are constructed from zero-coupon bond prices using the yield curve from Gurkaynak et al. (2006). ${ }^{16}$ Having controlled for interest rates in this manner, we find that banks and Top banks exhibit a large and significant decrease in their cost of capital after the passage of the DFA relative to both the SCAP and Basel I period. The decrease of approximately $4.5 \%$ relative to the Basel I period is large relative to both the CAPM and FF3 models (column 3). The Top regression confirms that the largest banks are driving this result, with a differential decline of $3 \%$ relative to the SCAP period and $5 \%$ relative to the Basel I period (column 4).

\subsection{CAPM with a time-varying equity risk premium}

A time-varying equity risk premium that is correlated with bank betas may bias our baseline CAPM results that assume a constant equity risk premium. For example, if bank betas and the equity risk premium decline from the SCAP period to the Dodd-Frank period, our estimate of the decline in the cost of capital for banks assuming a constant risk premium

\footnotetext{
${ }^{16}$ The interest rate factors are $R_{\text {short }, t}=R_{2 y, t}-R_{f, t}$ and $R_{\text {slope }, t}=\frac{1}{5}\left(R_{10 y, t}-R_{f, t}\right)-\left(R_{2 y, t}-R_{f, t}\right)$ where $R_{2 y, t}$ and $R_{10 y, t}$ are the daily return for two-year and ten-year zero coupon bonds and $R_{f, t}$ is the daily risk-free rate. The slope factor has zero duration by construction and is $-99 \%(-74 \%)$ correlated with the change in the 10y-2y zero-coupon (constant maturity) slope at a daily frequency. The short term factor is $-99 \%$ (-94\%) correlated with the change in the $2 \mathrm{y}$ zero-coupon (constant maturity) yield at a daily frequency. The average factor risk premiums from 1975 to 2017 are $\mu_{\text {short }}=1.14 \%$ and $\mu_{\text {slope }}=-.41 \%$ (the average annualized excess return for the 10-year zero coupon bond is $3.67 \%$ ).
} 
will be underestimated, all else equal.

To address this concern we consider two approaches. First, we use a model to estimate the equity risk premium and then repeat our analysis for the CAPM with this time-varying risk premium. To do this, we form a one-factor partial least squares estimate of the equity risk premium by combining 14 models of the equity risk premium from Duarte and Rosa (2015). ${ }^{17}$ We then project one-year ahead CRSP value-weighted returns onto the partial least squares estimate and use the fitted value as a measure of the equity risk premium. This approach has the advantage that it directly addresses the concern that the equity risk premium is time varying but the disadvantage that the results are model and sample dependent.

For an alternative perspective, we take advantage of the fact that the equity risk premium drops out of a difference-in-differences analysis after taking the logarithm since the CAPM is a one-factor model. ${ }^{18}$ We thus estimate our difference-in-differences regressions using the logarithm of the CAPM betas as the dependent variable. We implement this idea empirically by winsorizing the estimated betas at .05 to remove negative values from the sample.

Table 8 reports the baseline regressions for the CAPM using the partial least squares estimate of the equity risk premium (PLS-Rf) in columns (5) and (6) and for the logarithm of the CAPM betas $(\log ($ Beta $))$ in columns $(7)$ and (8). ${ }^{19}$ For the PLS-Rf regressions almost all of the time period coefficients are larger than those in the specifications with a constant risk premium. This reflects the fact that our estimate of the time-varying equity risk premium has increased over the sample period, consistent with the findings in Duarte and Rosa (2015). For banks, the results are qualitatively consistent with those from the

\footnotetext{
${ }^{17}$ Similar results hold by projecting one-year ahead returns onto the estimate of the equity risk premium from a dividend discount model, which is one of the 14 models included in the partial least squares estimate.

${ }^{18}$ In particular, $\log \left(\beta_{i, t} \mu_{t}\right)-\log \left(\beta_{i, t-1} \mu_{t-1}\right)-\left(\log \left(\beta_{j, t} \mu_{t}\right)-\log \left(\beta_{j, t-1} \mu_{t-1}\right)\right)=\log \left(\beta_{i, t}\right)-\log \left(\beta_{i, t-1}\right)-$ $\left(\log \left(\beta_{j, t}\right)-\log \left(\beta_{j, t-1}\right)\right)$. This argument does not apply to multifactor models.

${ }^{19}$ The PLS-Rf results are from March 1996 to 2016 when the equity risk premium estimates are available from Duarte and Rosa (2015). This results in a slightly shorter sample period compared to the other regressions.
} 
other CAPM specifications, in that the estimated cost of capital is higher in the Dodd-Frank period relative to the Basel I period but significantly lower than the SCAP period. Column (5) indicates that the cost of capital for banks has declined by around $9 \%$ from the SCAP period to the Dodd-Frank period. Column (6) shows that these results are again driven by the very largest banks. In comparison to the previous results, the larger magnitudes suggest that the assumption of a constant equity risk premium may be biasing our results down, or that bank betas are positively correlated with the equity risk premium.

Similar results also hold when taking the logarithm of the CAPM betas as the dependent variable in columns (7) and (8). For example, columns (7) and (8) indicate that bank CAPM betas have declined by about 35\% from SCAP to Dodd-Frank with much of the decline being driven by the largest banks. One difference from the PLS-Rf results in column (6) is the negative and significant coefficient on Bank x Top x Dodd-Frank in column (8). The negative coefficient for log betas is consistent with the CAPM, three-factor, and five-factor cost of capital estimates using constant factor risk premiums which all indicate that the cost of capital for the largest banks has declined relative to both the Basel I and SCAP periods on a within-firm, value-weighted basis.

\subsection{Asset betas}

The key component driving changes in our baseline cost of capital analysis is the estimate of CAPM equity betas. In this way, the analysis captures changes to the systematic risk of the banking industry. However, since these estimates are affected by leverage, we may also be interested in studying asset betas to understand how the systematic risk of banking assets has evolved, regardless of capital structure changes. We compute asset betas in the Merton (1974) model using equity market capitalization and equity volatility for each firm- 
month observation in the sample following the approach in Bharath and Shumway (2008). ${ }^{20}$ This analysis directly incorporates leverage into the estimated beta rather than including leverage as a linear control variable in reduced form regressions as in Table 5 (specification 5) or in Table 6 (specification 6 ) (where leverage is measured by the Tier 1 capital ratio). The disadvantage of this approach is that the computation of asset betas is model specific and requires a number of assumptions, such as how to compute the maturity and face value of debt. These assumptions may be particularly important for banks.

Columns (9) and (10) in Table 8 report the results with asset beta as the dependent variable. Looking at the bank interaction coefficients on the regulatory time periods, we still estimate a significant decrease in banks' asset betas between the SCAP and Dodd-Frank periods that is primarily driven by the very largest banks. This result is noteworthy as the significant decline persists despite the decrease in bank leverage in recent years, which would imply increased asset betas if equity betas were unchanged. From a longer historical perspective, asset betas for the Top banks have differentially increased relative to the Basel I period by around .10 as measured by the significant and positive Bank x Top x Dodd-Frank coefficient in column (10). This result differs from the cost of equity capital estimates which generally feature a negative difference for the largest banks for the analogous coefficient.

\subsection{Weighted average cost of capital}

Given that the vast majority of bank assets are financed with debt and deposits, an equity based measure may not reflect the average (nor marginal) financing cost for a bank. Therefore, we repeat our analysis for the weighted average cost of capital (WACC), another

\footnotetext{
${ }^{20} \mathrm{We}$ compute asset betas by solving for firm value and volatility from two nonlinear equations for the value of equity and equity volatility, similar to how the default probability $\pi_{\text {Merton }}^{\text {simul }}$ is computed in Bharath and Shumway (2008). To do this we assume that debt matures in one year and define the face value of debt as short-term debt plus one-half long-term debt plus deposits if available. In a previous draft we found similar results by assuming that debt was riskless as in Baker and Wurgler (2015) in which case asset betas are equal to $\beta_{i, t}^{\text {asset }}=\beta_{i, t}\left(1-L_{i, t}\right)$ where $L_{i, t}=D_{i, t} /\left(D_{i, t}+M E_{i, t}\right)$.
} 
commonly used measure of the cost of capital that takes into account the after-tax cost of debt, cost of equity, and capital structure. While a WACC approach to allocating capital is less frequently cited by bank managers, if it is used, the changes to the cost of equity capital that we estimate may be offset by changes in the cost of deposits and debt, altering our conclusions. We thus estimate WACC from merged CRSP-Compustat data as,

$$
\mathrm{WACC}_{i t}=\mathrm{CAPM}_{i t} \cdot \frac{M E_{i t}}{D_{i t}+M E_{i t}}+\mathrm{Rd}_{i t} \cdot\left(1-\tau_{i t}\right) \cdot \frac{D_{i t}}{D_{i t}+M E_{i t}},
$$

where $\mathrm{CAPM}_{i t}$ is the CAPM cost of equity capital, $\mathrm{Rd}_{i t}$ is the cost of debt, $\tau_{i t}$ is the effective tax rate, $D_{i t}$ is total debt, and $M E_{i t}$ is market equity. ${ }^{21}$ When defining total debt for banks, we add the total amount of deposits to capture this important component of bank leverage. The resulting leverage is $79 \%$ for banks and $20 \%$ for non-banks on average (see Table 2). Note also that our cost of debt and effective tax rate measures are based on interest and tax expense from the income statement. These accounting measures may adjust slowly over time. This differs from our estimates of the cost of equity capital which are based on market prices, but is consistent with empirical evidence on sticky deposit pricing and is a similar approach to other studies computing the cost of bank debt such as Dick-Nielsen et al. (2019).

Table 9 reports the difference-in-differences regressions using WACC-Rf as the dependent variable. The first column (1) indicates that value-weighted WACC-Rf has increased by about $1 \%$ over the past twenty years for all firms. The second column (2) indicates that bank WACC-Rf is almost $6 \%$ lower than non-bank WACC-Rf on average, reflecting the high

\footnotetext{
${ }^{21}$ The cost of debt is a one-year moving average of quarterly interest expense over total debt which includes deposits. Total debt is long-term debt (Item DLTTQ) plus short-term debt (Item DLCQ) plus deposits if available (Item DPTCQ). Depending on availability, we use Item XINTQ or Item TIEQ in that order for quarterly interest expense. The effective tax rate is a one-year moving median of quarterly income taxes (Item TXTQ) over pre-tax income (Item PIQ). We winsorize the cost of debt, the effective tax rate, and market leverage at the $1 \%$ and $99 \%$ percentiles to mitigate the impact of outliers and measurement error. This data cleaning step is performed separately for financials and non-financials each month to allow for differences in firm characteristics and time trends, such as the high leverage of financial firms and the lower cost of debt and tax rates in recent years.
} 
leverage and low cost of debt for banks relative to non-banks. The second (2) and third (3) columns indicate that WACC-Rf has fallen for banks between the SCAP and DoddFrank periods by around 1\%, but increased between the Dodd-Frank and Basel I periods by around 1.5\%. For the Top banks we see a further decrease in WACC-Rf by around 20 to 30 basis points in the specifications with firm fixed effects and the equal-weighted regression without fixed effects (specifications 5, 6, 7), but an increase in the value-weighted regression without fixed effects of around 15 basis points (specification 4). In contrast to the previous results, the changes for Top Banks are not significant when comparing the SCAP and DoddFrank periods, although we still see a decline across most specifications. For the cost of equity capital we consistently find a large and significant decline for the Top banks when comparing the SCAP and Dodd-Frank periods.

\section{Conclusion}

This paper investigates how the CAPM cost of capital for banks has changed over time in comparison to other firms. After spiking in the financial crisis, the CAPM cost of capital for the banking industry has differentially declined since the passage of the Dodd-Frank Act. The very largest banks most affected by post-crisis regulations have experienced a significant decline in their cost of capital relative to both the financial crisis and the late 1990s. This is striking in the face of research such as Atkeson et al. (2018) that suggests that the value of government guarantees are falling over the same period of time.

Ultimately, these questions are not just of academic interest. The cost of capital for banks is an input into decisions about lending quantities and pricing as well as decisions regarding resource allocation to different business lines. This paper provides new evidence that changes in the CAPM cost of capital matter for the supply and pricing of loans. The 
results suggest that bank managers are reacting to changes in the systematic risk captured in their stock price, even after accounting for business cycle fluctuations and firm-specific shocks to stock market returns. Increases in banks' CAPM cost of capital are associated with tighter lending conditions, pricing, and quantity. Our estimates of the cost of capital are capturing changes in market prices that matter to bank managers and the supply of credit. 


\section{References}

Abadie, A., A. Diamond, and J. Hainmueller (2010). Synthetic control methods for comparative case studies: Estimating the effect of california's tobacco control program. Journal of the American statistical Association 105(490), 493-505.

Admati, A. R., P. M. DeMarzo, M. F. Hellwig, and P. C. Pfleiderer (2014). Fallacies and irrelevant facts in the debate on capital regulation. In Central Banks at a Crossroads: Europe and Beyond, pp. 33-50. London: Anthem Press.

Adrian, T., E. Friedman, and T. Muir (2015). The cost of capital of the financial sector. Federal Reserve Bank of New York Staff Report.

Ang, A. and D. Kristensen (2012). Testing conditional factor models. Journal of Financial Economics 106(1), 132-156.

Atkeson, A. G., A. d'Avernas, A. L. Eisfeldt, and P.-O. Weill (2018). Government guarantees and the valuation of american banks. NBER Macroeconomics Annual.

Baker, M. and J. Wurgler (2015). Do strict capital requirements raise the cost of capital? bank regulation, capital structure, and the low-risk anomaly. American Economic Review: Papers 83 Proceedings 105(5), $315-320$.

Bassett, W. F., M. B. Chosak, J. C. Driscoll, and E. Zakrajšek (2014). Changes in bank lending standards and the macroeconomy. Journal of Monetary Economics 62, 23-40.

Berk, J. B. and J. H. van Binsbergen (2016). Assessing asset pricing models using revealed preference. Journal of Financial Economics 119(1), 1-23.

Bharath, S. T. and T. Shumway (2008). Forecasting default with the merton distance to default model. The Review of Financial Studies 21 (3), 1339-1369.

Black, F., M. C. Jensen, and M. S. Scholes (1972). The capital asset pricing model: Some empirical tests. In M. C. Jensen (Ed.), Studies in the Theory of Capital Markets, pp. 79-121. New York, NY: Praeger.

Calomiris, C. W. and D. Nissim (2014). Crisis-related shifts in the market valuation of banking activities. Journal of Financial Intermediation 23, 400-435.

Choi, D. B., M. R. Holcomb, and D. P. Morgan (2019). Bank leverage limits and regulatory arbitrage: Old question, new evidence. Working Paper.

Cochrane, J. H. (2011). Presidential address: Discount rates. The Journal of Finance 66(4), 1047-1108.

Demsetz, R. S. and P. E. Strahan (1997). Diversification, size, and risk at bank holding companies. Journal of Money, Credit, and Banking 29(3), 300-313.

DeYoung, R., A. Gron, G. Torna, and A. Winton (2015). Risk overhang and loan portfolio decisions: small business loan supply before and during the financial crisis. The Journal of Finance 70(6), 2451-2488.

Dick-Nielsen, J., J. Gyntelberg, and C. Thimsen (2019). The cost of capital for banks. Working Paper.

Duarte, F. and C. Rosa (2015). The equity risk premium: A review of models. Federal Reserve Bank of New York Economic Policy Review 21(2), 39-57.

Fama, E. F. (1970). Efficient capital markets: A review of theory and empirical work. The Journal of Finance 25(2), 383-417. 
Fama, E. F. and K. R. French (1993). Common risk factors in the returns on stocks and bonds. Journal of Financial Economics 33(1), 3-56.

Fama, E. F. and K. R. French (1997). Industry costs of equity. Journal of Financial Economics 43(2), 153-193.

Flannery, M., B. Hirtle, and A. Kovner (2017). Evaluating the information in the federal reserve stress tests. Journal of Financial Intermediation 29, 1-18.

Frank, M. Z. and T. Shen (2016). Investment and the weighted average cost of capital. Journal of Financial Economics 119(2), 300-315.

Frazzini, A. and L. H. Pedersen (2014). Betting against beta. Journal of Financial Economics 111(1), 1-25.

Freyaldenhoven, S., C. Hansen, and J. M. Shapiro (2019). Pre-event trends in the panel event-study design. American Economic Review $109(9), 3307-38$.

Gandhi, P. and H. Lustig (2015). Size anomalies in u.s. bank stock returns. The Journal of Finance 70(2), $733-768$.

Gilson, S. C., E. S. Hotchkiss, and R. S. Ruback (2000). Valuation of bankrupt firms. The Review of Financial Studies 13(1), 43-74.

Graham, J. R. and C. R. Harvey (2001). The theory and practice of corporate finance: evidence from the field. Journal of Financial Economics 60(2-3), 187-243.

Gurkaynak, R., B. Sack, and J. Wright (2006). The us treasury curve: 1961 to present. Journal of Monetary Economics 54(8), 2291-2304.

Hale, G. and J. Santos (2014). Do banks propagate shocks to the debt market? Journal of Financial Economic Policy 6(3), 270-310.

Hirtle, B. (2009). Credit derivatives and bank credit supply. Journal of Financial Intermediation 18(2), $125-150$.

Hong, H. and D. A. Sraer (2016). Speculative betas. The Journal of Finance 71 (5), 2095-2144.

Hou, K., C. Xue, and L. Zhang (2014). Digesting anomalies: An investment approach. Review of Financial Studies 28(3), 650-704.

Huizinga, H. and L. Laeven (2012). Bank valuation and accounting discretion during a financial crisis. Journal of Financial Economics 106(3), 614-634.

Kelly, B., H. Lustig, and S. Van Nieuwerburgh (2016). Too-systemic-to-fail: What option markets imply about sector-wide government guarantees. American Economic Review 106(6), 1278-1319.

Khandani, A. E. and A. W. Lo (2011). What happened to the quants in august 2007? evidence from factors and transactions data. Journal of Financial Markets 14(1), 1-46.

Lown, C. and D. P. Morgan (2006). The credit cycle and the business cycle: New findings using the loan officer opinion survey. Journal of Money, Credit and Banking 38(6), 1575-1597.

Merton, R. C. (1974). On the pricing of corporate debt: The risk structure of interest rates. The Journal of Finance 29(2), 449-470.

Merton, R. C. (1980). On estimating the expected return on the market: An exploratory investigation. Journal of Financial Economics 8(4), 323-361. 
Minton, B. A., R. M. Stulz, and A. G. Taboada (2017). Are larger banks valued more highly? SSRN.

Mitchell, M. and T. Pulvino (2012). Arbitrage crashes and the speed of capital. Journal of Financial Economics 104(3), 469-490.

Modigliani, F. and M. H. Miller (1958). The cost of capital, corporation finance and the theory of investment. American Economic Review 48(3), 261-297.

Pennacchi, G. and J. A. Santos (2018). Why do banks target roe? Working Paper.

Roth, J. (2019). Pre-test with caution: Event-study estimates after testing for parallel trends. Working Paper.

Sarin, N. and L. H. Summers (2016). Understanding bank risk through market measures. Brookings Papers on Economic Activity, 57-127.

Schuermann, T. and K. J. Stiroh (2006). Visible and hidden risk factors for banks. Federal Reserve Bank of New York Staff Report.

Welch, I. and A. Goyal (2007). A comprehensive look at the empirical performance of equity premium prediction. The Review of Financial Studies 21(4), 1455-1508. 


\section{Table 1: Variable Definitions}

This table reports variable definitions. Panel A reports the cost of capital measures that are estimated from CRSP and Compustat data. Panel B reports the bank characteristics from call reports and Y-9C filings. Panel $\mathrm{C}$ reports the SLOOS questions on bank credit supply that are related to banks' CAPM cost of capital. The Federal Reserve mnemonics for the variables used to define the bank characteristics are reported in Appendix Table A.1. The core deposit measure and liquidity coverage measure are from Calomiris and Nissim (2014) and Choi et al. (2019) respectively.

\begin{tabular}{l|l}
\multicolumn{2}{l}{ Panel A: Cost of Capital Measures } \\
\hline Variable & Description \\
\hline CAPM & CAPM cost of capital $\mathrm{Rf}_{t}+\beta_{i t} \mu_{r m r f}$ \\
$\mathrm{Rf}$ & Risk-free rate $\mathrm{Rf}_{t}$ \\
CAPM Beta & CAPM beta $\beta_{i t}$ from rolling regressions with 1-year lagged daily data \\
FF3 - Rf & Fama-French risk premium $\beta_{i t}^{r m r f} \mu_{r m r f}+\beta_{i t}^{h m l} \mu_{h m l}+\beta_{i t}^{s m b} \mu_{s m b}$ \\
$\mathrm{IR}-\mathrm{Rf}$ & Five-factor risk premium $\sum_{f} \beta_{i t}^{f} \mu_{f}$ with FF3 and IR factors \\
PLS - Rf & CAPM risk premium $\beta_{i t} \mu_{t}$ with $\mu_{t}$ from partial least squares estimation \\
Asset Beta & Merton model asset beta $\beta_{i t}^{a s s e t}=\beta_{i t} \frac{E}{V} \frac{1}{N\left(d_{1}\right)}$ \\
WACC & Weighted average cost of capital $=C A P M_{i t} \cdot \frac{M E_{i t}}{D_{i t}+M E_{i t}}+R d_{i t}\left(1-\tau_{i t}\right) \frac{D_{i t}}{D_{i t}+M E_{i t}}$ \\
Leverage & Market Leverage $D_{i t} /\left(D_{i t}+M E_{i t}\right)$ \\
\hline
\end{tabular}

Panel B: Bank Characteristics

\begin{tabular}{l|l}
\hline Variable & Description \\
\hline Tier 1 Ratio & Tier 1 Risk Based Capital / Risk Weighted Assets \\
Core Deposits & Core Deposit Measure / Total Liabilities \\
Liquidity Coverage & 100 - (Liq. Adj. Liab. and Off-Balance Sheet Exp.) / Liq. Adj. Assets \\
Non Int. Inc. & Non-Int. Inc. / (Non-Int. Inc. + Net Int. Inc.) \\
Risk-Weighted Assets & Risk Weighted Assets / Total Assets \\
Cash + FF + Sec. & (Cash + FF Repos + AFS \& HTM Sec.) / Total Assets \\
Loans & Total Loans / Total Assets \\
Commitments & Unused Loan Commitments / Total Assets \\
Trading Assets & Trading Assets / Total Assets \\
Derivatives & (Total Gross Notional Derivatives + Securities Lent + Spot FX) / Total Assets \\
\hline
\end{tabular}

Panel C: Senior Loan Officer Opinion Survey on Bank Lending Practices

\begin{tabular}{l|l}
\hline Variable & Description \\
\hline Std & Change in lending standards \\
CCL & Change in cost of credit lines \\
Spd & Change in spread of loan rates over bank cost of funds \\
RP & Change in premiums charged on riskier loans \\
Cov & Change in loan covenants \\
Col & Change in collateral requirements \\
Max & Change in maximum size of credit lines \\
\hline
\end{tabular}


Table 2: Summary Statistics

This table reports variable summary statistics. Panel A reports statistics for the cost of capital measures separating banks and non-banks. Panel B reports statistics for the bank characteristic variables. Panel $\mathrm{C}$ reports statistics for the SLOOS variables. Similar to the regression analysis, the results are value-weighted in Panels $\mathrm{A}$ and $\mathrm{B}$ and equal-weighted in Panel $\mathrm{C}$ to focus on large banks. The sample period is March 1996 to December 2017.

\begin{tabular}{|c|c|c|c|c|c|c|c|}
\hline \multicolumn{8}{|l|}{ Panel A: Cost of Capital Measures } \\
\hline Panel A.I: Banks & mean & $\mathrm{sd}$ & $\mathrm{p} 25$ & $\mathrm{p} 50$ & p75 & count & \\
\hline CAPM & 11.49 & 3.28 & 9.28 & 11.28 & 13.61 & 142189 & \\
\hline CAPM - Rf & 9.32 & 3.38 & 7.13 & 9.15 & 11.22 & 142189 & \\
\hline CAPM Beta & 1.17 & 0.42 & 0.90 & 1.15 & 1.41 & 142189 & \\
\hline FF3 - Rf & 12.99 & 4.97 & 9.31 & 12.93 & 16.26 & 142189 & \\
\hline IR-Rf & 12.56 & 5.34 & 8.61 & 11.82 & 15.95 & 142189 & \\
\hline PLS-Rf & 8.35 & 9.32 & 0.96 & 7.19 & 14.28 & 137466 & \\
\hline $\log ($ Beta $)$ & 0.07 & 0.47 & -0.11 & 0.14 & 0.34 & 142189 & \\
\hline Asset Beta & 0.27 & 0.26 & 0.15 & 0.19 & 0.28 & 135781 & \\
\hline WACC-Rf & 1.43 & 2.36 & 0.02 & 1.30 & 1.99 & 128562 & \\
\hline Leverage & 79.42 & 15.80 & 78.46 & 83.79 & 87.44 & 135921 & \\
\hline Panel A.II: Non-Banks & mean & sd & p25 & p50 & p75 & count & \\
\hline CAPM & 10.04 & 4.23 & 7.13 & 9.42 & 12.33 & 968938 & \\
\hline CAPM - Rf & 7.89 & 3.59 & 5.59 & 7.50 & 9.68 & 968938 & \\
\hline CAPM Beta & 0.99 & 0.45 & 0.70 & 0.94 & 1.22 & 968938 & \\
\hline FF3 - Rf & 7.45 & 5.82 & 4.08 & 6.76 & 10.15 & 968938 & \\
\hline IR-Rf & 7.52 & 6.35 & 3.92 & 6.77 & 10.42 & 968938 & \\
\hline PLS-Rf & 6.35 & 7.30 & 0.61 & 6.78 & 11.27 & 935494 & \\
\hline $\log ($ Beta $)$ & -0.13 & 0.56 & -0.35 & -0.06 & 0.20 & 968938 & \\
\hline Asset Beta & 0.83 & 0.42 & 0.55 & 0.80 & 1.04 & 754664 & \\
\hline WACC-Rf & 6.24 & 2.96 & 4.30 & 6.00 & 7.83 & 521126 & \\
\hline Leverage & 19.55 & 18.05 & 6.52 & 14.40 & 26.91 & 754751 & \\
\hline Panel B: Bank Characteristics & mean & sd & $\mathrm{p} 25$ & $\mathrm{p} 50$ & $\mathrm{p} 75$ & count & \\
\hline Tier 1 Ratio & 11.04 & 3.92 & 8.37 & 10.09 & 12.58 & 99734 & \\
\hline Core Deposits & 38.84 & 20.25 & 20.64 & 40.10 & 54.97 & 99734 & \\
\hline Liquidity Coverage & 59.87 & 18.72 & 44.61 & 59.91 & 75.22 & 99734 & \\
\hline Non-Interest Income & 47.44 & 18.08 & 37.11 & 46.20 & 55.30 & 99734 & \\
\hline Risk-Weighted Assets & 71.86 & 14.12 & 60.90 & 72.48 & 81.86 & 99734 & \\
\hline Cash + FF + Sec. & 30.13 & 12.00 & 21.89 & 28.35 & 35.70 & 99734 & \\
\hline Loans & 51.51 & 19.06 & 37.55 & 54.37 & 67.25 & 99734 & \\
\hline Commitments & 46.15 & 23.82 & 28.90 & 44.85 & 64.39 & 99734 & \\
\hline Trading Assets & 6.09 & 5.95 & 0.30 & 3.52 & 13.93 & 99734 & \\
\hline Derivatives & 434.95 & 420.32 & 21.04 & 279.44 & 952.00 & 99734 & \\
\hline \multicolumn{8}{|l|}{ Panel C: SLOOS Variables } \\
\hline Panel C.I: Lg. and Mid. Mkt. firms & Std & CCL & Spd & $\mathrm{RP}$ & Cov & Col & $\operatorname{Max}$ \\
\hline mean & 0.06 & -0.02 & -0.12 & 0.19 & 0.00 & 0.05 & 0.01 \\
\hline sd & 0.46 & 0.64 & 0.76 & 0.66 & 0.52 & 0.39 & 0.53 \\
\hline count & 3954 & 3934 & 3934 & 3480 & 3935 & 3931 & 3933 \\
\hline Panel C.II: Small firms & Std & CCL & Spd & $\mathrm{RP}$ & $\mathrm{Cov}$ & $\mathrm{Col}$ & Max \\
\hline mean & 0.06 & -0.02 & -0.11 & 0.16 & 0.03 & 0.06 & 0.01 \\
\hline sd & 0.42 & 0.54 & 0.67 & 0.57 & 0.44 & 0.36 & 0.36 \\
\hline count & 3847 & 3805 & 3805 & 3367 & 3805 & 3800 & 3802 \\
\hline
\end{tabular}


Table 3: The CAPM Cost of Capital and Lending Supply

This table reports regressions of quarterly changes in lending standards as measured by survey responses onto one-year changes in the CAPM risk premium from March 1996 to December 2017. Panel A regresses the change in lending standards (Std) onto different specifications that include one-year changes in the risk-free rate and one-year realized bank-level stock market returns and quarter fixed effects. Panels $\mathrm{B}$ and $\mathrm{C}$ regress changes in lending terms that banks are willing to approve to large and middle-market firms (LM) and small firms (S) onto one-year changes in the CAPM risk premium with quarter fixed effects. The loan terms include the cost of credit lines (CCL), the spread of loan rates over bank's cost of funds (Spd), the premiums charged on riskier loans (RP), loan covenants (Cov), collateralization requirements $(\mathrm{Col})$, and the maximum size of credit lines (Max). The positive and significant coefficients across specifications and loan terms in Panels A and B are consistent with the interpretation that bank managers tighten credit standards and charge wider spreads for large and middle-market firms when their cost of capital increases. Standard errors are clustered by bank and quarter with ${ }^{*},{ }^{* *},{ }^{* *}$ indicating significance at the $10 \%, 5 \%$, and $1 \%$ levels.

$$
\operatorname{SLOOS}_{i t}=\alpha+\eta \cdot \Delta\left(\mathrm{CAPM}_{i t}-\mathrm{Rf}_{t}\right)+e_{i t}
$$

\begin{tabular}{|c|c|c|c|c|c|c|}
\hline & $(1)$ & $(2)$ & $(3)$ & $(4)$ & $(5)$ & $(6)$ \\
\hline \multicolumn{7}{|c|}{ Panel A: $\Delta$ Lending Standards (equal-weighted) } \\
\hline \multirow{3}{*}{$\Delta\left(\mathrm{CAPM}_{i t}-\mathrm{Rf}_{t}\right)$} & Std-LM & Std-LM & Std-LM & Std-S & Std-S & Std-S \\
\hline & $0.024^{* * *}$ & $0.012^{* * *}$ & $0.011^{* *}$ & $0.021^{* * *}$ & $0.010^{* *}$ & $0.007^{*}$ \\
\hline & $(0.007)$ & $(0.004)$ & $(0.005)$ & $(0.007)$ & $(0.004)$ & $(0.004)$ \\
\hline \multirow[t]{2}{*}{$\Delta \mathrm{Rf}_{t}$} & & $-0.131^{* * *}$ & & & $-0.114^{* * *}$ & \\
\hline & & $(0.020)$ & & & $(0.018)$ & \\
\hline \multirow{2}{*}{$\operatorname{Ret}_{i t}$} & & $-0.002^{* * *}$ & & & $-0.002^{* * *}$ & \\
\hline & & $(0.001)$ & & & $(0.001)$ & \\
\hline Observations & 3776 & 3776 & 3776 & 3672 & 3672 & 3672 \\
\hline Adjusted R-squared & 0.019 & 0.159 & 0.262 & 0.018 & 0.153 & 0.241 \\
\hline Quarter Fixed Effects & No & No & Yes & No & No & Yes \\
\hline
\end{tabular}

Panel B: $\Delta$ Loan terms for large and middle-market firms (equal weighted with quarter fixed effects)

\begin{tabular}{lcccccc}
\hline & $\mathrm{CCL}$ & $\mathrm{Spd}$ & $\mathrm{RP}$ & $\mathrm{Cov}$ & $\mathrm{Col}$ & $\mathrm{Max}$ \\
$\Delta\left(\mathrm{CAPM}_{i t}-\mathrm{Rf}_{t}\right)$ & $0.015^{* *}$ & $0.018^{* * *}$ & $0.016^{* *}$ & $0.012^{* *}$ & 0.006 & $0.008^{*}$ \\
& $(0.007)$ & $(0.007)$ & $(0.006)$ & $(0.005)$ & $(0.004)$ & $(0.005)$ \\
Observations & 3760 & 3760 & 3462 & 3761 & 3757 & 3759 \\
Adjusted R-squared & 0.304 & 0.366 & 0.313 & 0.209 & 0.185 & 0.180 \\
\hline
\end{tabular}

Panel C: $\Delta$ Loan terms for small firms (equal weighted with quarter fixed effects)

\begin{tabular}{lcccccc}
\hline & CCL & Spd & RP & Cov & Col & Max \\
$\Delta\left(\mathrm{CAPM}_{i t}-\mathrm{Rf}_{t}\right)$ & 0.006 & 0.005 & 0.008 & 0.006 & 0.004 & 0.004 \\
& $(0.006)$ & $(0.006)$ & $(0.006)$ & $(0.004)$ & $(0.004)$ & $(0.005)$ \\
Observations & 3639 & 3639 & 3351 & 3639 & 3634 & 3636 \\
Adjusted R-squared & 0.256 & 0.318 & 0.267 & 0.171 & 0.157 & 0.138 \\
\hline \hline
\end{tabular}


Table 4: The CAPM Cost of Capital for Banks Compared to Other Industries

This table reports the CAPM cost of capital for banks over time relative to other industries. Regressions are value-weighted by market capitalization or equal-weighted with some specifications including firm fixed effects. Specification (4) is restricted to banks and non-bank financials where financials are defined as firms with two-digit SIC codes between 60 and 69 . The sample includes monthly observations for 11,961 companies in CRSP-Compustat from March 1996 to December 2017. Standard errors are clustered by firm and month with ${ }^{*},{ }^{* *},{ }^{* *}$ indicating significance at the $10 \%, 5 \%$, and $1 \%$ levels respectively.

$\mathrm{CAPM}_{i t}-\mathrm{Rf}_{t}=\alpha+\beta_{1} \mathrm{GLB}_{t}+\beta_{2}$ Crisis $_{t}+\beta_{3} \mathrm{SCAP}_{t}+\beta_{4}$ Dodd-Frank $_{t}+\rho$ Bank $_{i t}$ $+\delta_{1}$ Bank $_{i t} \mathrm{GLB}_{t}+\delta_{2}$ Bank $_{i t}$ Crisis $_{t}+\delta_{3}$ Bank $_{i t} \mathrm{SCAP}_{t}+\delta_{4}$ Bank $_{i t}$ Dodd-Frank $_{t}+e_{i t}$

\begin{tabular}{|c|c|c|c|c|c|c|c|c|}
\hline & $\begin{array}{c}(1) \\
\text { CAPM - Rf }\end{array}$ & $\begin{array}{c}(2) \\
\text { CAPM - Rf }\end{array}$ & $\begin{array}{c}(3) \\
\text { CAPM - Rf } \\
\end{array}$ & $\begin{array}{c}(4) \\
\text { CAPM - Rf }\end{array}$ & $\begin{array}{c}(5) \\
\text { CAPM - Rf }\end{array}$ & $\begin{array}{c}(6) \\
\text { CAPM - Rf }\end{array}$ & $\begin{array}{c}(7) \\
\text { CAPM - Rf }\end{array}$ & $\begin{array}{c}(8) \\
\text { CAPM - Rf }\end{array}$ \\
\hline GLB & $\begin{array}{l}-0.21 \\
(0.18)\end{array}$ & $\begin{array}{c}-0.10 \\
(0.20)\end{array}$ & $\begin{array}{c}-0.82^{* * *} \\
(0.20)\end{array}$ & $\begin{array}{c}-1.69^{* * *} \\
(0.45)\end{array}$ & $\begin{array}{c}1.24^{* * *} \\
(0.19)\end{array}$ & $\begin{array}{c}1.48^{* * *} \\
(0.21)\end{array}$ & $\begin{array}{c}0.83^{* * *} \\
(0.20)\end{array}$ & $\begin{array}{c}0.46^{* *} \\
(0.23)\end{array}$ \\
\hline Crisis & $\begin{array}{l}-0.11 \\
(0.21)\end{array}$ & $\begin{array}{l}-0.35 \\
(0.22)\end{array}$ & $\begin{array}{c}-0.92^{* * * *} \\
(0.26)\end{array}$ & $\begin{array}{l}1.02^{* *} \\
(0.43)\end{array}$ & $\begin{array}{c}2.02^{* * *} \\
(0.14)\end{array}$ & $\begin{array}{c}2.08^{* * *} \\
(0.15)\end{array}$ & $\begin{array}{c}1.05^{* * *} \\
(0.16)\end{array}$ & $\begin{array}{c}3.11^{* * *} \\
(0.31)\end{array}$ \\
\hline SCAP & $\begin{array}{c}0.36 \\
(0.31)\end{array}$ & $\begin{array}{l}-0.28 \\
(0.25)\end{array}$ & $\begin{array}{c}-0.82^{* * * *} \\
(0.28)\end{array}$ & $\begin{array}{c}2.33^{* * *} \\
(0.73)\end{array}$ & $\begin{array}{c}3.21^{* * *} \\
(0.18)\end{array}$ & $\begin{array}{c}3.29^{* * *} \\
(0.19)\end{array}$ & $\begin{array}{c}2.16^{* * *} \\
(0.20)\end{array}$ & $\begin{array}{c}4.08^{* * *} \\
(0.41)\end{array}$ \\
\hline Dodd-Frank & $\begin{array}{l}-0.09 \\
(0.20)\end{array}$ & $\begin{array}{l}-0.26 \\
(0.22)\end{array}$ & $\begin{array}{c}-0.98^{* * *} \\
(0.24)\end{array}$ & $\begin{array}{c}0.00 \\
(0.45)\end{array}$ & $\begin{array}{c}3.28^{* * *} \\
(0.15)\end{array}$ & $\begin{array}{c}3.41^{* * *} \\
(0.15)\end{array}$ & $\begin{array}{c}2.14^{* * *} \\
(0.16)\end{array}$ & $\begin{array}{c}2.25^{* * *} \\
(0.30)\end{array}$ \\
\hline Bank & & $\begin{array}{l}0.65^{*} \\
(0.37)\end{array}$ & $\begin{array}{c}-3.17^{* * *} \\
(0.47)\end{array}$ & $\begin{array}{c}-3.22^{* * *} \\
(0.52)\end{array}$ & & $\begin{array}{c}-2.34^{* * *} \\
(0.18)\end{array}$ & $\begin{array}{c}-2.32^{* * *} \\
(0.54)\end{array}$ & $\begin{array}{c}-2.20^{* * *} \\
(0.57)\end{array}$ \\
\hline Bank x GLB & & $\begin{array}{c}-1.04^{* *} \\
(0.43)\end{array}$ & $\begin{array}{l}-0.60 \\
(0.41)\end{array}$ & $\begin{array}{c}0.28 \\
(0.56)\end{array}$ & & $\begin{array}{c}-1.13^{* * *} \\
(0.21)\end{array}$ & $\begin{array}{c}0.34 \\
(0.24)\end{array}$ & $\begin{array}{c}0.71^{* * *} \\
(0.23)\end{array}$ \\
\hline Bank $\mathrm{x}$ Crisis & & $\begin{array}{c}2.97^{* * *} \\
(0.55)\end{array}$ & $\begin{array}{c}3.37^{* * *} \\
(0.60)\end{array}$ & $\begin{array}{c}1.43^{* * *} \\
(0.54)\end{array}$ & & $\begin{array}{c}0.29 \\
(0.28)\end{array}$ & $\begin{array}{c}2.45^{* * *} \\
(0.30)\end{array}$ & $\begin{array}{c}0.39 \\
(0.35)\end{array}$ \\
\hline Bank x SCAP & & $\begin{array}{c}6.56^{* * *} \\
(0.87)\end{array}$ & $\begin{array}{c}6.92^{* * *} \\
(0.95)\end{array}$ & $\begin{array}{c}3.75^{* * *} \\
(1.03)\end{array}$ & & $\begin{array}{c}0.03 \\
(0.33)\end{array}$ & $\begin{array}{c}2.36^{* * *} \\
(0.34)\end{array}$ & $\begin{array}{c}0.43 \\
(0.43)\end{array}$ \\
\hline Bank x Dodd-Frank & & $\begin{array}{c}1.90^{* * *} \\
(0.45)\end{array}$ & $\begin{array}{c}2.48^{* * *} \\
(0.54)\end{array}$ & $\begin{array}{l}1.48^{* *} \\
(0.63)\end{array}$ & & $\begin{array}{l}-0.42^{*} \\
(0.25)\end{array}$ & $\begin{array}{c}1.75^{* * *} \\
(0.27)\end{array}$ & $\begin{array}{c}1.64^{* * *} \\
(0.34)\end{array}$ \\
\hline Observations & 1111127 & 1111127 & 1111062 & 223432 & 1111127 & 1111127 & 1111062 & 223432 \\
\hline Adjusted $R^{2}$ & 0.001 & 0.042 & 0.544 & 0.588 & 0.062 & 0.102 & 0.536 & 0.635 \\
\hline Fixed Effects & No & No & Yes & Yes & No & No & Yes & Yes \\
\hline Weighting & VW & VW & VW & VW & EW & EW & EW & EW \\
\hline Sample & All Firms & All Firms & All Firms & Banks+NBF & All Firms & All Firms & All Firms & Banks+NBF \\
\hline
\end{tabular}




\section{Table 5: The CAPM Cost of Capital for the Largest Banks}

This table reports the differential CAPM cost of capital for the largest banks over time relative to large firms in other industries. Top $i t$ is an indicator variable equal to one when a firm is among the 20 largest firms as measured by assets within its Fama-French 12 industry in month- $t$. Regressions are value-weighted by market capitalization or equal-weighted with some specifications including firm fixed effects. Standard errors are clustered by firm and month with ${ }^{*},{ }^{* *},{ }^{* *}$ indicating significance at the $10 \%, 5 \%$, and $1 \%$ levels.

$$
\begin{aligned}
& \mathrm{CAPM}_{i t}-\mathrm{Rf}_{t}=\alpha+\beta_{1} \mathrm{GLB}_{t}+\beta_{2} \mathrm{Crisis}_{t}+\beta_{3} \mathrm{SCAP}_{t}+\beta_{4} \text { Dodd-Frank }_{t}+\rho \text { Bank }_{i t}+\eta \text { Top }_{i t} \\
& +\nu \text { Bank }_{i t} \text { Top }_{i t}+\delta_{1} \text { Bank }_{i t} \text { GLB }_{t}+\delta_{2} \text { Bank }_{i t} \text { Crisis }_{t}+\delta_{3} \text { Bank }_{i t} \text { SCAP }_{t}+\delta_{4} \text { Bank }_{i t} \text { Dodd-Frank }_{t} \\
& +\chi_{1} \operatorname{Top}_{i t} \text { GLB }_{t}+\chi_{2} \text { Top }_{i t} \text { Crisis }_{t}+\chi_{3} \text { Top }_{i t} \text { SCAP }_{t}+\chi_{4} \text { Top }_{i t} \text { Dodd-Frank }_{t}+\gamma_{1} \text { Bank }_{i t} \text { Top }_{i t} \text { GLB }_{t} \\
& +\gamma_{2} \text { Bank }_{i t} \text { Top }_{i t} \text { Crisis }_{t}+\gamma_{3} \text { Bank }_{i t} \text { Top }_{i t} \text { SCAP }_{t}+\gamma_{4} \text { Bank }_{i t} \text { Top }_{i t} \text { Dodd-Frank }_{t}+\phi \text { Leverage }_{i t}+e_{i t}
\end{aligned}
$$

\begin{tabular}{|c|c|c|c|c|c|c|c|}
\hline & $\begin{array}{c}(1) \\
\text { CAPM - Rf }\end{array}$ & $\begin{array}{c}(2) \\
\text { CAPM - Rf }\end{array}$ & $\begin{array}{c}(3) \\
\text { CAPM - Rf }\end{array}$ & $\begin{array}{c}(4) \\
\text { CAPM - Rf }\end{array}$ & $\begin{array}{c}(5) \\
\text { CAPM - Rf }\end{array}$ & $\begin{array}{c}(6) \\
\text { CAPM - Rf }\end{array}$ & $\begin{array}{c}(7) \\
\text { CAPM - Rf }\end{array}$ \\
\hline GLB & $\begin{array}{l}-0.23 \\
(0.19)\end{array}$ & $\begin{array}{c}1.54^{* * *} \\
(0.23)\end{array}$ & $\begin{array}{c}0.66^{* * *} \\
(0.19)\end{array}$ & $\begin{array}{l}-0.20 \\
(0.27)\end{array}$ & $\begin{array}{c}0.80^{* * *} \\
(0.17)\end{array}$ & $\begin{array}{c}1.55^{* * *} \\
(0.21)\end{array}$ & $\begin{array}{c}0.91^{* * *} \\
(0.21)\end{array}$ \\
\hline Crisis & $\begin{array}{l}-0.10 \\
(0.21)\end{array}$ & $\begin{array}{c}0.60^{* *} \\
(0.23)\end{array}$ & $\begin{array}{l}-0.11 \\
(0.23)\end{array}$ & $\begin{array}{c}1.24^{* * *} \\
(0.45)\end{array}$ & $\begin{array}{l}0.45^{* *} \\
(0.20)\end{array}$ & $\begin{array}{c}2.10^{* * *} \\
(0.15)\end{array}$ & $\begin{array}{c}1.06^{* * *} \\
(0.17)\end{array}$ \\
\hline SCAP & $\begin{array}{c}0.34 \\
(0.29)\end{array}$ & $\begin{array}{c}1.25^{* * *} \\
(0.26)\end{array}$ & $\begin{array}{l}0.47^{*} \\
(0.26)\end{array}$ & $\begin{array}{c}2.01^{* * * *} \\
(0.52)\end{array}$ & $\begin{array}{c}1.32^{* * *} \\
(0.23)\end{array}$ & $\begin{array}{c}3.34^{* * *} \\
(0.20)\end{array}$ & $\begin{array}{c}2.18^{* * *} \\
(0.21)\end{array}$ \\
\hline Dodd-Frank & $\begin{array}{l}-0.10 \\
(0.21)\end{array}$ & $\begin{array}{c}1.22^{* * *} \\
(0.22)\end{array}$ & $\begin{array}{c}0.36 \\
(0.23)\end{array}$ & $\begin{array}{l}0.67^{*} \\
(0.34)\end{array}$ & $\begin{array}{c}0.94^{* * *} \\
(0.21)\end{array}$ & $\begin{array}{c}3.53^{* * *} \\
(0.16)\end{array}$ & $\begin{array}{c}2.24^{* * *} \\
(0.18)\end{array}$ \\
\hline Bank & $\begin{array}{c}-0.91^{* * *} \\
(0.28)\end{array}$ & $\begin{array}{c}-1.20^{* * *} \\
(0.40)\end{array}$ & $\begin{array}{c}-2.99^{* * *} \\
(0.54)\end{array}$ & $\begin{array}{c}-3.27^{* * *} \\
(0.55)\end{array}$ & $\begin{array}{c}-2.47^{* * *} \\
(0.62)\end{array}$ & $\begin{array}{c}-2.50^{* * *} \\
(0.17)\end{array}$ & $\begin{array}{c}-1.85^{* * *} \\
(0.57)\end{array}$ \\
\hline Top & $\begin{array}{c}-1.46^{* * *} \\
(0.22)\end{array}$ & $\begin{array}{l}0.46 \\
(0.31)\end{array}$ & $\begin{array}{c}1.24^{* * *} \\
(0.43)\end{array}$ & $\begin{array}{c}1.04 \\
(0.66)\end{array}$ & $\begin{array}{c}1.70^{* * *} \\
(0.42)\end{array}$ & $\begin{array}{c}1.71^{* * *} \\
(0.19)\end{array}$ & $\begin{array}{c}1.08^{* * *} \\
(0.26)\end{array}$ \\
\hline Bank x Top & $\begin{array}{c}3.41^{* * *} \\
(0.40)\end{array}$ & $\begin{array}{c}3.17^{* * *} \\
(0.53)\end{array}$ & $\begin{array}{c}0.11 \\
(0.61)\end{array}$ & $\begin{array}{c}0.24 \\
(0.75)\end{array}$ & $\begin{array}{l}-0.48 \\
(0.60)\end{array}$ & $\begin{array}{c}5.19^{* * *} \\
(0.30)\end{array}$ & $\begin{array}{c}0.35 \\
(0.54)\end{array}$ \\
\hline Bank x GLB & & $\begin{array}{l}-0.92^{*} \\
(0.50)\end{array}$ & $\begin{array}{c}0.00 \\
(0.37)\end{array}$ & $\begin{array}{l}0.88^{* *} \\
(0.39)\end{array}$ & $\begin{array}{l}-0.20 \\
(0.33)\end{array}$ & $\begin{array}{c}-1.08^{* * * *} \\
(0.22)\end{array}$ & $\begin{array}{l}0.42^{*} \\
(0.24)\end{array}$ \\
\hline Bank x Crisis & & $\begin{array}{c}2.51^{* * *} \\
(0.62)\end{array}$ & $\begin{array}{c}3.72^{* * *} \\
(0.52)\end{array}$ & $\begin{array}{c}2.41^{* * *} \\
(0.60)\end{array}$ & $\begin{array}{c}3.37^{* * *} \\
(0.44)\end{array}$ & $\begin{array}{c}0.25 \\
(0.28)\end{array}$ & $\begin{array}{c}2.49^{* * *} \\
(0.31)\end{array}$ \\
\hline Bank x SCAP & & $\begin{array}{c}3.02^{* * *} \\
(0.65)\end{array}$ & $\begin{array}{c}4.43^{* * *} \\
(0.65)\end{array}$ & $\begin{array}{c}2.95^{* * *} \\
(0.75)\end{array}$ & $\begin{array}{c}3.94^{* * *} \\
(0.57)\end{array}$ & $\begin{array}{l}-0.16 \\
(0.32)\end{array}$ & $\begin{array}{c}2.30^{* * *} \\
(0.34)\end{array}$ \\
\hline Bank x Dodd-Frank & & $\begin{array}{c}1.69^{* * * *} \\
(0.46)\end{array}$ & $\begin{array}{c}3.26^{* * *} \\
(0.39)\end{array}$ & $\begin{array}{c}3.02^{* * *} \\
(0.44)\end{array}$ & $\begin{array}{c}2.73^{* * *} \\
(0.39)\end{array}$ & $\begin{array}{c}-0.52^{* *} \\
(0.25)\end{array}$ & $\begin{array}{c}1.81^{* * *} \\
(0.27)\end{array}$ \\
\hline Top x GLB & & $\begin{array}{c}-2.55^{* * *} \\
(0.41)\end{array}$ & $\begin{array}{c}-2.18^{* * *} \\
(0.34)\end{array}$ & $\begin{array}{c}-2.73^{* * *} \\
(0.70)\end{array}$ & $\begin{array}{c}-2.36^{* * *} \\
(0.33)\end{array}$ & $\begin{array}{c}-1.54^{* * *} \\
(0.25)\end{array}$ & $\begin{array}{c}-1.23^{* * *} \\
(0.25)\end{array}$ \\
\hline Top $\mathrm{x}$ Crisis & & $\begin{array}{c}-1.47^{* * *} \\
(0.39)\end{array}$ & $\begin{array}{c}-1.14^{* * *} \\
(0.39)\end{array}$ & $\begin{array}{c}0.08 \\
(0.66)\end{array}$ & $\begin{array}{c}-1.53^{* * *} \\
(0.39)\end{array}$ & $\begin{array}{c}-0.90^{* * *} \\
(0.25)\end{array}$ & $\begin{array}{l}-0.31 \\
(0.27)\end{array}$ \\
\hline Top x SCAP & & $\begin{array}{c}-2.34^{* * *} \\
(0.42)\end{array}$ & $\begin{array}{c}-1.86^{* * *} \\
(0.44)\end{array}$ & $\begin{array}{c}2.08 \\
(1.37)\end{array}$ & $\begin{array}{c}-2.56^{* * *} \\
(0.43)\end{array}$ & $\begin{array}{c}-1.23^{* * *} \\
(0.36)\end{array}$ & $\begin{array}{l}-0.43 \\
(0.35)\end{array}$ \\
\hline Top x Dodd-Frank & & $\begin{array}{c}-2.28^{* * *} \\
(0.36)\end{array}$ & $\begin{array}{c}-1.91^{* * *} \\
(0.37)\end{array}$ & $\begin{array}{l}-0.83 \\
(0.77)\end{array}$ & $\begin{array}{c}-2.32^{* * * *} \\
(0.37)\end{array}$ & $\begin{array}{c}-2.26^{* * *} \\
(0.26)\end{array}$ & $\begin{array}{c}-1.43^{* * *} \\
(0.28)\end{array}$ \\
\hline Bank x Top x GLB & & $\begin{array}{l}-0.54 \\
(0.71)\end{array}$ & $\begin{array}{c}-1.06^{*} \\
(0.55)\end{array}$ & $\begin{array}{l}-0.52 \\
(0.85)\end{array}$ & $\begin{array}{l}-0.72 \\
(0.54)\end{array}$ & $\begin{array}{c}-1.31^{* * *} \\
(0.38)\end{array}$ & $\begin{array}{c}-2.36^{* * *} \\
(0.39)\end{array}$ \\
\hline Bank x Top x Crisis & & $\begin{array}{c}0.02 \\
(0.80)\end{array}$ & $\begin{array}{l}-0.79 \\
(0.74)\end{array}$ & $\begin{array}{c}-2.03^{* *} \\
(0.85)\end{array}$ & $\begin{array}{l}-0.32 \\
(0.68)\end{array}$ & $\begin{array}{l}1.31^{* *} \\
(0.62)\end{array}$ & $\begin{array}{l}-0.23 \\
(0.65)\end{array}$ \\
\hline Bank x Top x SCAP & & $\begin{array}{c}3.81^{* * *} \\
(1.01)\end{array}$ & $\begin{array}{c}2.79^{* * *} \\
(1.07)\end{array}$ & $\begin{array}{l}-1.23 \\
(1.65)\end{array}$ & $\begin{array}{c}3.26^{* * *} \\
(1.02)\end{array}$ & $\begin{array}{c}4.21^{* * *} \\
(0.85)\end{array}$ & $\begin{array}{l}2.06^{* *} \\
(0.87)\end{array}$ \\
\hline Bank x Top x Dodd-Frank & & $\begin{array}{l}-0.23 \\
(0.66)\end{array}$ & $\begin{array}{l}-1.23^{*} \\
(0.64)\end{array}$ & $\begin{array}{c}-2.41^{* *} \\
(0.96)\end{array}$ & $\begin{array}{l}-0.77 \\
(0.66)\end{array}$ & $\begin{array}{c}0.25 \\
(0.50)\end{array}$ & $\begin{array}{c}-1.82^{* * *} \\
(0.52)\end{array}$ \\
\hline Leverage & & & & & $\begin{array}{l}-0.00 \\
(0.01)\end{array}$ & & \\
\hline Observations & 1111127 & 1111127 & 1111062 & 223432 & 890583 & 1111127 & 1111062 \\
\hline Adjusted $R^{2}$ & 0.055 & 0.095 & 0.554 & 0.616 & 0.564 & 0.109 & 0.537 \\
\hline Fixed Effects & No & No & Yes & Yes & Yes & No & Yes \\
\hline Weighting & VW & VW & VW & VW & VW & EW & EW \\
\hline Sample & All Firms & All Firms & All Firms & Banks+NBF & All Firms & All Firms & All Firms \\
\hline
\end{tabular}


Table 6: The CAPM Cost of Capital for Banks Controlling for Characteristics

This table reports the CAPM cost of capital for banks over time controlling for bank characteristics. The panel includes bank-month observations for which the regulatory characteristic variables are available from call reports and Y-9C filings. The results are reported for the CAPM risk premium in value-weighted regressions with firm fixed effects. Column (1) reports how the cost of capital has evolved over time for banks. The results are similar to the bank interaction coefficients in column (3) of Table 4. Columns (2) through (6) show the impact of controlling for different characteristics individually. Column (7) includes all of the characteristics together. Standard errors are clustered by firm and month with ${ }^{*},{ }^{* *},{ }^{* *}$ indicating significance at the $10 \%, 5 \%$, and $1 \%$ levels. The sample period is March 1996 to December 2017.

$\mathrm{CAPM}_{i t}-\mathrm{Rf}_{t}=\alpha+\beta_{1} \mathrm{GLB}_{t}+\beta_{2} \mathrm{Crisis}_{t}+\beta_{3} \mathrm{SCAP}_{t}+\beta_{4}$ Dodd-Frank $_{t}+\theta X_{i t}+e_{i t}$

\begin{tabular}{|c|c|c|c|c|c|c|c|}
\hline & $\begin{array}{c}(1) \\
\text { CAPM - Rf }\end{array}$ & $\begin{array}{c}(2) \\
\text { CAPM - Rf }\end{array}$ & $\begin{array}{c}(3) \\
\text { CAPM - Rf }\end{array}$ & $\begin{array}{c}(4) \\
\text { CAPM - Rf }\end{array}$ & $\begin{array}{c}(5) \\
\text { CAPM - Rf }\end{array}$ & $\begin{array}{c}(6) \\
\text { CAPM - Rf }\end{array}$ & $\begin{array}{c}(7) \\
\text { CAPM - Rf }\end{array}$ \\
\hline GLB & $\begin{array}{c}-1.49^{* * *} \\
(0.38)\end{array}$ & $\begin{array}{c}-1.48^{* * *} \\
(0.38)\end{array}$ & $\begin{array}{c}-1.50^{* * *} \\
(0.38)\end{array}$ & $\begin{array}{c}-1.53^{* * *} \\
(0.39)\end{array}$ & $\begin{array}{c}-1.50^{* * *} \\
(0.38)\end{array}$ & $\begin{array}{c}-1.47^{* * *} \\
(0.37)\end{array}$ & $\begin{array}{c}-1.47^{* * *} \\
(0.36)\end{array}$ \\
\hline Crisis & $\begin{array}{c}2.46^{* * *} \\
(0.58)\end{array}$ & $\begin{array}{c}2.46^{* * *} \\
(0.57)\end{array}$ & $\begin{array}{c}2.43^{* * *} \\
(0.59)\end{array}$ & $\begin{array}{c}2.37^{* * *} \\
(0.58)\end{array}$ & $\begin{array}{c}2.46^{* * *} \\
(0.58)\end{array}$ & $\begin{array}{c}2.49^{* * *} \\
(0.54)\end{array}$ & $\begin{array}{c}2.39^{* * *} \\
(0.55)\end{array}$ \\
\hline SCAP & $\begin{array}{c}6.44^{* * *} \\
(0.93)\end{array}$ & $\begin{array}{c}6.49^{* * *} \\
(0.90)\end{array}$ & $\begin{array}{c}6.57^{* * *} \\
(0.93)\end{array}$ & $\begin{array}{c}6.67^{* * *} \\
(0.88)\end{array}$ & $\begin{array}{c}6.44^{* * *} \\
(0.92)\end{array}$ & $\begin{array}{c}6.55^{* * *} \\
(0.89)\end{array}$ & $\begin{array}{c}6.78^{* * *} \\
(0.85)\end{array}$ \\
\hline Dodd-Frank & $\begin{array}{c}1.53^{* * *} \\
(0.51)\end{array}$ & $\begin{array}{c}1.61^{* * *} \\
(0.51)\end{array}$ & $\begin{array}{c}1.78^{* * *} \\
(0.50)\end{array}$ & $\begin{array}{c}1.96^{* * *} \\
(0.43)\end{array}$ & $\begin{array}{c}1.53^{* * *} \\
(0.51)\end{array}$ & $\begin{array}{c}1.71^{* * *} \\
(0.47)\end{array}$ & $\begin{array}{c}2.14^{* * *} \\
(0.42)\end{array}$ \\
\hline Tier 1 Ratio & & $\begin{array}{l}-0.02 \\
(0.06)\end{array}$ & & & & & $\begin{array}{c}0.06 \\
(0.08)\end{array}$ \\
\hline Core Deposits & & & $\begin{array}{c}-0.04^{* *} \\
(0.02)\end{array}$ & & & & $\begin{array}{l}-0.03^{*} \\
(0.02)\end{array}$ \\
\hline Liq. Coverage & & & & $\begin{array}{c}-0.03^{* *} \\
(0.01)\end{array}$ & & & $\begin{array}{l}-0.02^{*} \\
(0.01)\end{array}$ \\
\hline Non Int. Inc. & & & & & $\begin{array}{c}0.00 \\
(0.01)\end{array}$ & & $\begin{array}{l}-0.01 \\
(0.01)\end{array}$ \\
\hline RWA & & & & & & $\begin{array}{c}0.03^{* *} \\
(0.01)\end{array}$ & $\begin{array}{l}0.03^{*} \\
(0.02)\end{array}$ \\
\hline Observations & 99728 & 99728 & 99728 & 99728 & 99728 & 99728 & 99728 \\
\hline Adjusted $R^{2}$ & 0.575 & 0.575 & 0.580 & 0.579 & 0.575 & 0.578 & 0.584 \\
\hline Fixed Effects & Yes & Yes & Yes & Yes & Yes & Yes & Yes \\
\hline Weighting & VW & VW & VW & VW & VW & VW & VW \\
\hline Sample & Banks & Banks & Banks & Banks & Banks & Banks & Banks \\
\hline
\end{tabular}


Table 7: The Impact of Stress Testing on the Cost of Capital

This table reports the cost of capital for the largest 90 banks by assets each month with regulatory data from March 1996 to December 2017. The sample includes 227 banks in total and separates the Dodd-Frank period into Dodd-Frank: Pre-CCAR from July 2010 through August 2013 and Dodd-Frank: Post-CCAR from September 2013 through December 2017. SCAP Firm is a binary variable equal to 1 for banks included in the initial round of stress testing. CCAR Firm is a binary variable equal to 1 for banks that were later added to stress testing. Results are reported for expected excess returns in the CAPM and FF3 models. Regressions are equal-weighted with some specifications including firm fixed effects and control variables for bank characteristics. Standard errors are clustered by firm and month with ${ }^{*},{ }^{* *},{ }^{* *}$ indicating significance at the 10\%, 5\%, and 1\% levels. The sample period is March 1996 to December 2017.

$$
\begin{aligned}
& \mathrm{CAPM}_{i t}-\mathrm{Rf}_{t}=\alpha+\beta_{1} \mathrm{GLB}_{t}+\beta_{2} \mathrm{Crisis}_{t}+\beta_{3} \mathrm{SCAP}_{t}+\beta_{4} \mathrm{PreCCAR}_{t}+\beta_{5} \text { PostCCAR }_{t} \\
& +\rho \text { SCAP Firm } i+\eta \text { CCAR Firm }_{i}+\delta_{1} \text { SCAP Firm }_{i} \mathrm{SCAP}_{t}+\delta_{2} \mathrm{SCAP} \mathrm{Firm}_{i} \text { PreCCAR }_{t} \\
& +\delta_{3} \text { SCAP Firm }_{i} \text { Post CCAR }_{t}+\gamma \text { CCAR Firm }_{i} \text { PostCCAR }_{t}+\theta X_{i t}+e_{i t}
\end{aligned}
$$

\begin{tabular}{|c|c|c|c|c|c|c|c|c|}
\hline & $\begin{array}{c}(1) \\
\text { CAPM - Rf }\end{array}$ & $\begin{array}{c}(2) \\
\text { CAPM - Rf }\end{array}$ & $\begin{array}{c}(3) \\
\text { CAPM - Rf }\end{array}$ & $\begin{array}{c}(4) \\
\text { CAPM - Rf }\end{array}$ & $\begin{array}{c}(5) \\
\text { FF3 - Rf }\end{array}$ & $\begin{array}{c}(6) \\
\text { FF3 - Rf }\end{array}$ & $\begin{array}{c}(7) \\
\text { FF3 - Rf }\end{array}$ & $\begin{array}{c}(8) \\
\text { FF3 - Rf }\end{array}$ \\
\hline GLB & $\begin{array}{l}0.57^{*} \\
(0.30)\end{array}$ & $\begin{array}{l}0.57^{*} \\
(0.31)\end{array}$ & $\begin{array}{c}0.26 \\
(0.29)\end{array}$ & $\begin{array}{c}0.04 \\
(0.27)\end{array}$ & $\begin{array}{c}-4.77^{* * *} \\
(0.40)\end{array}$ & $\begin{array}{c}-4.77^{* * *} \\
(0.40)\end{array}$ & $\begin{array}{c}-4.74^{* * *} \\
(0.43)\end{array}$ & $\begin{array}{c}-4.88^{* * *} \\
(0.43)\end{array}$ \\
\hline Crisis & $\begin{array}{c}4.77^{* * *} \\
(0.42)\end{array}$ & $\begin{array}{c}4.76^{* * *} \\
(0.42)\end{array}$ & $\begin{array}{l}4.42^{* * *} \\
(0.46)\end{array}$ & $\begin{array}{c}3.99^{* * *} \\
(0.44)\end{array}$ & $\begin{array}{c}5.12^{* * *} \\
(0.81)\end{array}$ & $\begin{array}{c}5.12^{* * *} \\
(0.81)\end{array}$ & $\begin{array}{c}5.33^{* * *} \\
(0.86)\end{array}$ & $\begin{array}{c}5.09^{* * *} \\
(0.84)\end{array}$ \\
\hline SCAP & $\begin{array}{c}6.97^{* * *} \\
(0.61)\end{array}$ & $\begin{array}{c}6.57^{* * *} \\
(0.61)\end{array}$ & $\begin{array}{c}6.41^{* * *} \\
(0.62)\end{array}$ & $\begin{array}{c}6.20^{* * *} \\
(0.59)\end{array}$ & $\begin{array}{l}1.68^{* *} \\
(0.73)\end{array}$ & $\begin{array}{l}1.45^{*} \\
(0.76)\end{array}$ & $\begin{array}{l}1.95^{* *} \\
(0.80)\end{array}$ & $\begin{array}{l}1.87^{* *} \\
(0.76)\end{array}$ \\
\hline Dodd-Frank: Pre-CCAR & $\begin{array}{c}3.94^{* * *} \\
(0.33)\end{array}$ & $\begin{array}{c}3.97^{* * *} \\
(0.35)\end{array}$ & $\begin{array}{c}4.01^{* * *} \\
(0.39)\end{array}$ & $\begin{array}{c}4.05^{* * *} \\
(0.36)\end{array}$ & $\begin{array}{c}0.50 \\
(0.55)\end{array}$ & $\begin{array}{c}0.16 \\
(0.57)\end{array}$ & $\begin{array}{c}1.02 \\
(0.66)\end{array}$ & $\begin{array}{l}1.10^{*} \\
(0.62)\end{array}$ \\
\hline Dodd-Frank: Post-CCAR & $\begin{array}{c}3.54^{* * *} \\
(0.40)\end{array}$ & $\begin{array}{c}3.78^{* * *} \\
(0.42)\end{array}$ & $\begin{array}{c}3.91^{* * *} \\
(0.47)\end{array}$ & $\begin{array}{c}3.73^{* * *} \\
(0.44)\end{array}$ & $\begin{array}{l}1.17^{* *} \\
(0.49)\end{array}$ & $\begin{array}{c}1.46^{* * *} \\
(0.53)\end{array}$ & $\begin{array}{c}2.90^{* * *} \\
(0.63)\end{array}$ & $\begin{array}{c}2.78^{* * *} \\
(0.59)\end{array}$ \\
\hline SCAP Firm & $\begin{array}{c}1.04^{* * *} \\
(0.30)\end{array}$ & $\begin{array}{c}1.24^{* * *} \\
(0.36)\end{array}$ & & & $\begin{array}{l}-0.11 \\
(0.43)\end{array}$ & $\begin{array}{l}-0.17 \\
(0.45)\end{array}$ & & \\
\hline CCAR Firm & $\begin{array}{c}0.20 \\
(0.42)\end{array}$ & $\begin{array}{c}0.22 \\
(0.46)\end{array}$ & & & $\begin{array}{l}-0.50 \\
(0.59)\end{array}$ & $\begin{array}{l}-0.45 \\
(0.53)\end{array}$ & & \\
\hline CCAR Firm x DF: Post-CCAR & & $\begin{array}{l}-0.16 \\
(0.40)\end{array}$ & $\begin{array}{l}-0.54 \\
(0.40)\end{array}$ & $\begin{array}{c}0.15 \\
(0.38)\end{array}$ & & $\begin{array}{l}-0.23 \\
(0.75)\end{array}$ & $\begin{array}{l}-1.08 \\
(0.71)\end{array}$ & $\begin{array}{l}-0.82 \\
(0.69)\end{array}$ \\
\hline SCAP Firm $x$ SCAP & & $\begin{array}{c}1.99^{* * *} \\
(0.72)\end{array}$ & $\begin{array}{l}1.93^{* *} \\
(0.74)\end{array}$ & $\begin{array}{c}2.32^{* * *} \\
(0.73)\end{array}$ & & $\begin{array}{l}1.21 \\
(0.90)\end{array}$ & $\begin{array}{c}1.02 \\
(0.96)\end{array}$ & $\begin{array}{l}1.18 \\
(0.96)\end{array}$ \\
\hline SCAP Firm x DF: Pre-CCAR & & $\begin{array}{l}-0.26 \\
(0.54)\end{array}$ & $\begin{array}{l}-0.52 \\
(0.54)\end{array}$ & $\begin{array}{l}-0.14 \\
(0.53)\end{array}$ & & $\begin{array}{l}1.68^{*} \\
(0.90)\end{array}$ & $\begin{array}{c}1.12 \\
(0.88)\end{array}$ & $\begin{array}{l}1.31 \\
(0.89)\end{array}$ \\
\hline SCAP Firm x DF: Post-CCAR & & $\begin{array}{c}-1.21^{* * * *} \\
(0.44)\end{array}$ & $\begin{array}{c}-1.55^{* * *} \\
(0.47)\end{array}$ & $\begin{array}{c}-1.01^{* *} \\
(0.46)\end{array}$ & & $\begin{array}{l}-1.27^{*} \\
(0.72)\end{array}$ & $\begin{array}{c}-2.37^{* * *} \\
(0.75)\end{array}$ & $\begin{array}{c}-2.07^{* * *} \\
(0.78)\end{array}$ \\
\hline Tier 1 Ratio & & & & $\begin{array}{l}-0.01 \\
(0.19)\end{array}$ & & & & $\begin{array}{l}-0.01 \\
(0.23)\end{array}$ \\
\hline Observations & 22984 & 22984 & 22984 & 22984 & 22984 & 22984 & 22984 & 22984 \\
\hline Adjusted $R^{2}$ & 0.376 & 0.382 & 0.588 & 0.598 & 0.375 & 0.380 & 0.555 & 0.556 \\
\hline Fixed Effects & No & No & Yes & Yes & No & No & Yes & Yes \\
\hline Controls & No & No & No & Yes & No & No & No & Yes \\
\hline Weighting & EW & EW & EW & EW & EW & EW & EW & EW \\
\hline
\end{tabular}


Table 8: Alternate Cost of Capital Estimates for Banks

This table reports the differential cost of capital for banks and for the largest banks for the different measures from Section 5 . The regression specifications are the same as in Tables 4 and 5 but vary the cost of capital measure to be from the Fama-French three-factor model in columns 1-2, a multifactor model with interest rate factors in columns 3-4, a CAPM model with a time-varying equity risk premium in columns 5-6, the logarithm of CAPM betas in columns 7-8, and asset betas in columns 9-10. Regressions are value-weighted by market capitalization with some specifications including firm fixed effects. Standard errors are clustered by firm and month with *, ${ }^{* *},{ }^{* * *}$ indicating significance at the 10\%, 5\%, and 1\% levels. The sample period is March 1996 to December 2017.

\begin{tabular}{|c|c|c|c|c|c|c|c|c|c|c|}
\hline & $\begin{array}{c}(1) \\
\text { FF3 - Rf }\end{array}$ & $\begin{array}{c}(2) \\
\text { FF3 - Rf }\end{array}$ & $\begin{array}{c}(3) \\
\text { IR-Rf }\end{array}$ & $\begin{array}{c}(4) \\
\text { IR-Rf }\end{array}$ & $\begin{array}{c}(5) \\
\text { PLS-Rf }\end{array}$ & $\begin{array}{c}(6) \\
\text { PLS-Rf }\end{array}$ & $\begin{array}{c}(7) \\
\log (\text { Beta })\end{array}$ & $\begin{array}{c}(8) \\
\log (\text { Beta })\end{array}$ & $\begin{array}{c}(9) \\
\text { Asset Beta }\end{array}$ & $\begin{array}{c}(10) \\
\text { Asset Beta }\end{array}$ \\
\hline GLB & $\begin{array}{c}1.30^{* * *} \\
(0.43)\end{array}$ & $\begin{array}{l}0.68^{*} \\
(0.37)\end{array}$ & $\begin{array}{c}1.11^{* * *} \\
(0.41)\end{array}$ & $\begin{array}{c}0.50 \\
(0.39)\end{array}$ & $\begin{array}{c}5.24^{* * *} \\
(0.61)\end{array}$ & $\begin{array}{c}5.21^{* * *} \\
(0.68)\end{array}$ & $\begin{array}{c}-0.20^{* * *} \\
(0.04)\end{array}$ & $\begin{array}{c}0.06^{* *} \\
(0.03)\end{array}$ & $\begin{array}{c}-0.11^{* * *} \\
(0.03)\end{array}$ & $\begin{array}{c}0.07^{* * *} \\
(0.02)\end{array}$ \\
\hline Crisis & $\begin{array}{c}0.54 \\
(0.52)\end{array}$ & $\begin{array}{l}-0.53 \\
(0.42)\end{array}$ & $\begin{array}{c}0.54 \\
(0.51)\end{array}$ & $\begin{array}{l}-0.54 \\
(0.45)\end{array}$ & $\begin{array}{c}9.62^{* * *} \\
(0.81)\end{array}$ & $\begin{array}{c}9.47^{* * *} \\
(0.82)\end{array}$ & $\begin{array}{c}-0.09^{* *} \\
(0.04)\end{array}$ & $\begin{array}{c}0.08^{* * *} \\
(0.03)\end{array}$ & $\begin{array}{c}-0.13^{* * *} \\
(0.03)\end{array}$ & $\begin{array}{l}-0.00 \\
(0.02)\end{array}$ \\
\hline SCAP & $\begin{array}{l}1.40^{* *} \\
(0.56)\end{array}$ & $\begin{array}{c}0.59 \\
(0.40)\end{array}$ & $\begin{array}{l}1.37^{* *} \\
(0.55)\end{array}$ & $\begin{array}{c}0.52 \\
(0.43)\end{array}$ & $\begin{array}{c}14.76^{* * *} \\
(0.64)\end{array}$ & $\begin{array}{c}16.15^{* * *} \\
(0.57)\end{array}$ & $\begin{array}{c}-0.10^{* *} \\
(0.04)\end{array}$ & $\begin{array}{c}0.12^{* * *} \\
(0.03)\end{array}$ & $\begin{array}{c}-0.13^{* * *} \\
(0.03)\end{array}$ & $\begin{array}{c}0.07^{* *} \\
(0.03)\end{array}$ \\
\hline Dodd-Frank & $\begin{array}{l}1.03^{*} \\
(0.54)\end{array}$ & $\begin{array}{l}-0.30 \\
(0.40)\end{array}$ & $\begin{array}{l}1.24^{* *} \\
(0.54)\end{array}$ & $\begin{array}{c}0.04 \\
(0.43)\end{array}$ & $\begin{array}{c}13.11^{* * *} \\
(0.46)\end{array}$ & $\begin{array}{c}14.31^{* * *} \\
(0.44)\end{array}$ & $\begin{array}{c}-0.10^{* * *} \\
(0.04)\end{array}$ & $\begin{array}{c}0.14^{* * *} \\
(0.03)\end{array}$ & $\begin{array}{c}-0.13^{* * *} \\
(0.03)\end{array}$ & $\begin{array}{l}0.05^{*} \\
(0.02)\end{array}$ \\
\hline Bank & $\begin{array}{c}0.91 \\
(1.32)\end{array}$ & $\begin{array}{l}-0.57 \\
(1.20)\end{array}$ & $\begin{array}{c}2.16 \\
(1.36)\end{array}$ & $\begin{array}{c}0.47 \\
(1.30)\end{array}$ & $\begin{array}{l}-1.10 \\
(1.34)\end{array}$ & $\begin{array}{c}1.32 \\
(1.47)\end{array}$ & $\begin{array}{c}-0.41^{* * *} \\
(0.07)\end{array}$ & $\begin{array}{c}-0.36^{* * *} \\
(0.07)\end{array}$ & $\begin{array}{c}-0.08^{*} \\
(0.04)\end{array}$ & $\begin{array}{c}0.02 \\
(0.05)\end{array}$ \\
\hline Bank x GLB & $\begin{array}{c}-7.58^{* * *} \\
(0.64)\end{array}$ & $\begin{array}{c}-4.84^{* * *} \\
(0.54)\end{array}$ & $\begin{array}{c}-6.49^{* * *} \\
(0.65)\end{array}$ & $\begin{array}{c}-3.40^{* * *} \\
(0.60)\end{array}$ & $\begin{array}{c}1.34^{* * *} \\
(0.32)\end{array}$ & $\begin{array}{c}0.56 \\
(0.39)\end{array}$ & $\begin{array}{c}0.06 \\
(0.06)\end{array}$ & $\begin{array}{l}0.10^{*} \\
(0.06)\end{array}$ & $\begin{array}{c}0.04 \\
(0.03)\end{array}$ & $\begin{array}{c}-0.08^{* * *} \\
(0.02)\end{array}$ \\
\hline Bank x Crisis & $\begin{array}{c}1.28 \\
(0.92)\end{array}$ & $\begin{array}{c}3.50^{* * *} \\
(0.93)\end{array}$ & $\begin{array}{c}1.07 \\
(0.90)\end{array}$ & $\begin{array}{c}4.22^{* * *} \\
(0.90)\end{array}$ & $\begin{array}{c}5.41^{* * *} \\
(0.77)\end{array}$ & $\begin{array}{c}2.90^{* * *} \\
(0.55)\end{array}$ & $\begin{array}{c}0.38^{* * * *} \\
(0.08)\end{array}$ & $\begin{array}{c}0.52^{* * * *} \\
(0.07)\end{array}$ & $\begin{array}{c}0.09^{* *} \\
(0.04)\end{array}$ & $\begin{array}{c}0.04 \\
(0.04)\end{array}$ \\
\hline Bank x SCAP & $\begin{array}{l}-0.58 \\
(1.09)\end{array}$ & $\begin{array}{l}-0.36 \\
(0.80)\end{array}$ & $\begin{array}{l}-0.80 \\
(1.15)\end{array}$ & $\begin{array}{c}0.29 \\
(0.99)\end{array}$ & $\begin{array}{c}14.07^{* * *} \\
(1.82)\end{array}$ & $\begin{array}{c}4.65^{* * *} \\
(0.87)\end{array}$ & $\begin{array}{c}0.67^{* * *} \\
(0.09)\end{array}$ & $\begin{array}{c}0.60^{* * *} \\
(0.08)\end{array}$ & $\begin{array}{c}0.18^{* * *} \\
(0.05)\end{array}$ & $\begin{array}{l}-0.01 \\
(0.04)\end{array}$ \\
\hline Bank x Dodd-Frank & $\begin{array}{l}-1.16 \\
(0.99)\end{array}$ & $\begin{array}{l}1.42^{* *} \\
(0.68)\end{array}$ & $\begin{array}{c}-4.47^{* * *} \\
(1.06)\end{array}$ & $\begin{array}{l}-1.06 \\
(0.71)\end{array}$ & $\begin{array}{c}5.39^{* * *} \\
(0.88)\end{array}$ & $\begin{array}{c}1.34^{* * *} \\
(0.51)\end{array}$ & $\begin{array}{c}0.32^{* * *} \\
(0.07)\end{array}$ & $\begin{array}{c}0.50^{* * *} \\
(0.06)\end{array}$ & $\begin{array}{c}0.04 \\
(0.04)\end{array}$ & $\begin{array}{l}-0.04 \\
(0.03)\end{array}$ \\
\hline Top & & $\begin{array}{c}-1.46^{*} \\
(0.78)\end{array}$ & & $\begin{array}{c}-1.57^{* *} \\
(0.76)\end{array}$ & & $\begin{array}{c}1.52^{* * *} \\
(0.50)\end{array}$ & & $\begin{array}{c}0.27^{* * *} \\
(0.06)\end{array}$ & & $\begin{array}{c}0.16^{* * *} \\
(0.05)\end{array}$ \\
\hline Bank x Top & & $\begin{array}{l}2.51^{* *} \\
(1.09)\end{array}$ & & $\begin{array}{l}2.95^{* *} \\
(1.15)\end{array}$ & & $\begin{array}{c}-3.81^{* * *} \\
(1.10)\end{array}$ & & $\begin{array}{l}-0.01 \\
(0.08)\end{array}$ & & $\begin{array}{c}-0.14^{* * *} \\
(0.05)\end{array}$ \\
\hline Top x GLB & & $\begin{array}{c}0.93 \\
(0.68)\end{array}$ & & $\begin{array}{c}0.93 \\
(0.67)\end{array}$ & & $\begin{array}{c}0.02 \\
(0.30)\end{array}$ & & $\begin{array}{c}-0.38^{* * *} \\
(0.06)\end{array}$ & & $\begin{array}{c}-0.26^{* * *} \\
(0.04)\end{array}$ \\
\hline Top $\mathrm{x}$ Crisis & & $\begin{array}{l}1.61^{* *} \\
(0.75)\end{array}$ & & $\begin{array}{l}1.63^{* *} \\
(0.75)\end{array}$ & & $\begin{array}{c}0.21 \\
(0.36)\end{array}$ & & $\begin{array}{c}-0.24^{* * *} \\
(0.06)\end{array}$ & & $\begin{array}{c}-0.17^{* * *} \\
(0.05)\end{array}$ \\
\hline Top x SCAP & & $\begin{array}{l}1.21 \\
(0.80)\end{array}$ & & $\begin{array}{c}1.29 \\
(0.81)\end{array}$ & & $\begin{array}{c}-2.17^{* * *} \\
(0.57)\end{array}$ & & $\begin{array}{c}-0.33^{* * *} \\
(0.07)\end{array}$ & & $\begin{array}{c}-0.28^{* * *} \\
(0.05)\end{array}$ \\
\hline Top x Dodd-Frank & & $\begin{array}{l}1.97^{* *} \\
(0.79)\end{array}$ & & $\begin{array}{l}1.81^{* *} \\
(0.79)\end{array}$ & & $\begin{array}{c}-1.88^{* * * *} \\
(0.46)\end{array}$ & & $\begin{array}{c}-0.35^{* * *} \\
(0.05)\end{array}$ & & $\begin{array}{c}-0.25^{* * *} \\
(0.04)\end{array}$ \\
\hline Bank x Top x GLB & & $\begin{array}{c}-4.20^{* * *} \\
(0.90)\end{array}$ & & $\begin{array}{c}-4.76^{* * *} \\
(0.91)\end{array}$ & & $\begin{array}{l}1.46^{* *} \\
(0.58)\end{array}$ & & $\begin{array}{l}-0.08 \\
(0.09)\end{array}$ & & $\begin{array}{c}0.16^{* * *} \\
(0.04)\end{array}$ \\
\hline Bank x Top x Crisis & & $\begin{array}{c}-3.46^{* * *} \\
(1.25)\end{array}$ & & $\begin{array}{c}-4.77^{* * *} \\
(1.19)\end{array}$ & & $\begin{array}{c}3.61^{* * *} \\
(0.81)\end{array}$ & & $\begin{array}{c}-0.22^{* *} \\
(0.09)\end{array}$ & & $\begin{array}{c}0.06 \\
(0.06)\end{array}$ \\
\hline Bank x Top x SCAP & & $\begin{array}{l}-0.95 \\
(1.35)\end{array}$ & & $\begin{array}{l}-2.15 \\
(1.45)\end{array}$ & & $\begin{array}{c}12.57^{* * *} \\
(1.78)\end{array}$ & & $\begin{array}{c}0.04 \\
(0.11)\end{array}$ & & $\begin{array}{c}0.26^{* * *} \\
(0.06)\end{array}$ \\
\hline Bank x Top x Dodd-Frank & & $\begin{array}{c}-3.97^{* * *} \\
(1.34) \\
\end{array}$ & & $\begin{array}{c}-5.10^{* * * *} \\
(1.33) \\
\end{array}$ & & $\begin{array}{c}5.90^{* * *} \\
(1.14) \\
\end{array}$ & & $\begin{array}{c}-0.25^{* * *} \\
(0.08)\end{array}$ & & $\begin{array}{c}0.12^{* *} \\
(0.05)\end{array}$ \\
\hline Observations & 1111062 & 1111062 & 1111062 & 1111062 & 1072888 & 1072888 & 1111062 & 1111062 & 890356 & 890356 \\
\hline Adjusted $R^{2}$ & 0.493 & 0.496 & 0.414 & 0.417 & 0.675 & 0.679 & 0.460 & 0.472 & 0.656 & 0.664 \\
\hline Fixed Effects & Yes & Yes & Yes & Yes & Yes & Yes & Yes & Yes & Yes & Yes \\
\hline Weighting & VW & VW & VW & VW & VW & VW & VW & VW & VW & VW \\
\hline Sample & All Firms & All Firms & All Firms & All Firms & All Firms & All Firms & All Firms & All Firms & All Firms & All Firms \\
\hline
\end{tabular}




\section{Table 9: Weighted Average Cost of Capital Estimates for Banks}

This table reports the differential weighted average cost of capital for banks and for the largest banks over time. The regression specifications are the same as in Tables 4 and 5 but use WACC$\mathrm{Rf}$ as the dependent variable rather than CAPM-Rf. Regressions are value-weighted by market capitalization or equal-weighted with some specifications including firm fixed effects. Standard errors are clustered by firm and month with ${ }^{*},{ }^{* *},{ }^{* * *}$ indicating significance at the $10 \%, 5 \%$, and 1\% levels. The sample period is March 1996 to December 2017.

\begin{tabular}{|c|c|c|c|c|c|c|c|}
\hline & $\begin{array}{c}(1) \\
\text { WACC-Rf }\end{array}$ & $\begin{array}{c}(2) \\
\text { WACC-Rf }\end{array}$ & $\begin{array}{c}(3) \\
\text { WACC-Rf }\end{array}$ & $\begin{array}{c}(4) \\
\text { WACC-Rf }\end{array}$ & $\begin{array}{c}(5) \\
\text { WACC-Rf }\end{array}$ & $\begin{array}{c}(6) \\
\text { WACC-Rf }\end{array}$ & $\begin{array}{c}(7) \\
\text { WACC-Rf }\end{array}$ \\
\hline GLB & $\begin{array}{l}-0.00 \\
(0.22)\end{array}$ & $\begin{array}{l}-0.08 \\
(0.23)\end{array}$ & $\begin{array}{c}-0.61^{* *} \\
(0.25)\end{array}$ & $\begin{array}{c}1.57^{* * *} \\
(0.18)\end{array}$ & $\begin{array}{c}0.84^{* * *} \\
(0.17)\end{array}$ & $\begin{array}{c}1.47^{* * *} \\
(0.21)\end{array}$ & $\begin{array}{c}1.00^{* * *} \\
(0.20)\end{array}$ \\
\hline Crisis & $\begin{array}{c}0.73^{* * *} \\
(0.27)\end{array}$ & $\begin{array}{c}0.41 \\
(0.27)\end{array}$ & $\begin{array}{l}-0.29 \\
(0.27)\end{array}$ & $\begin{array}{c}1.74^{* * *} \\
(0.20)\end{array}$ & $\begin{array}{c}0.87^{* * *} \\
(0.19)\end{array}$ & $\begin{array}{c}2.81^{* * *} \\
(0.11)\end{array}$ & $\begin{array}{c}1.92^{* * *} \\
(0.13)\end{array}$ \\
\hline SCAP & $\begin{array}{c}0.86^{* * *} \\
(0.29)\end{array}$ & $\begin{array}{l}0.55^{*} \\
(0.29)\end{array}$ & $\begin{array}{l}-0.21 \\
(0.29)\end{array}$ & $\begin{array}{c}2.39^{* * *} \\
(0.22)\end{array}$ & $\begin{array}{c}1.57^{* * *} \\
(0.21)\end{array}$ & $\begin{array}{c}3.83^{* * *} \\
(0.16)\end{array}$ & $\begin{array}{c}2.93^{* * *} \\
(0.18)\end{array}$ \\
\hline Dodd-Frank & $\begin{array}{c}0.93^{* * *} \\
(0.27)\end{array}$ & $\begin{array}{c}0.68^{* * *} \\
(0.26)\end{array}$ & $\begin{array}{l}-0.35 \\
(0.27)\end{array}$ & $\begin{array}{c}2.30^{* * *} \\
(0.19)\end{array}$ & $\begin{array}{c}1.31^{* * *} \\
(0.20)\end{array}$ & $\begin{array}{c}3.85^{* * *} \\
(0.12)\end{array}$ & $\begin{array}{c}2.92^{* * *} \\
(0.14)\end{array}$ \\
\hline Bank & & $\begin{array}{c}-5.94^{* * *} \\
(0.25)\end{array}$ & $\begin{array}{c}-2.20^{* * *} \\
(0.42)\end{array}$ & $\begin{array}{c}-5.54^{* * *} \\
(0.30)\end{array}$ & $\begin{array}{c}-0.89^{* *} \\
(0.45)\end{array}$ & $\begin{array}{c}-4.87^{* * *} \\
(0.11)\end{array}$ & $\begin{array}{l}-0.59 \\
(0.45)\end{array}$ \\
\hline Bank x GLB & & $\begin{array}{l}1.00^{* *} \\
(0.39)\end{array}$ & $\begin{array}{c}0.91^{* * *} \\
(0.30)\end{array}$ & $\begin{array}{c}0.13 \\
(0.63)\end{array}$ & $\begin{array}{l}-0.02 \\
(0.23)\end{array}$ & $\begin{array}{c}-0.48^{* *} \\
(0.23)\end{array}$ & $\begin{array}{l}-0.07 \\
(0.18)\end{array}$ \\
\hline Bank x Crisis & & $\begin{array}{c}1.92^{* * *} \\
(0.51)\end{array}$ & $\begin{array}{c}2.01^{* * *} \\
(0.37)\end{array}$ & $\begin{array}{c}1.35 \\
(1.06)\end{array}$ & $\begin{array}{c}1.42^{* * *} \\
(0.36)\end{array}$ & $\begin{array}{l}-0.41 \\
(0.25)\end{array}$ & $\begin{array}{l}0.56^{* *} \\
(0.26)\end{array}$ \\
\hline Bank x SCAP & & $\begin{array}{c}2.54^{* * *} \\
(0.51)\end{array}$ & $\begin{array}{c}2.56^{* * *} \\
(0.39)\end{array}$ & $\begin{array}{c}1.57 \\
(1.21)\end{array}$ & $\begin{array}{c}1.43^{* * *} \\
(0.29)\end{array}$ & $\begin{array}{c}-0.65^{* * *} \\
(0.19)\end{array}$ & $\begin{array}{c}0.32 \\
(0.20)\end{array}$ \\
\hline Bank x Dodd-Frank & & $\begin{array}{c}1.56^{* * *} \\
(0.42)\end{array}$ & $\begin{array}{c}1.70^{* * *} \\
(0.32)\end{array}$ & $\begin{array}{c}0.43 \\
(0.59)\end{array}$ & $\begin{array}{c}0.75^{* * *} \\
(0.25)\end{array}$ & $\begin{array}{c}-1.35^{* * *} \\
(0.13)\end{array}$ & $\begin{array}{c}-0.41^{* * *} \\
(0.15)\end{array}$ \\
\hline Top & & & & $\begin{array}{l}0.77^{* *} \\
(0.34)\end{array}$ & $\begin{array}{c}1.47^{* * *} \\
(0.38)\end{array}$ & $\begin{array}{c}1.05^{* * *} \\
(0.18)\end{array}$ & $\begin{array}{c}1.04^{* * *} \\
(0.22)\end{array}$ \\
\hline Bank x Top & & & & $\begin{array}{l}-0.53 \\
(0.42)\end{array}$ & $\begin{array}{c}-1.67^{* * *} \\
(0.43)\end{array}$ & $\begin{array}{c}0.14 \\
(0.20)\end{array}$ & $\begin{array}{c}-1.14^{* * *} \\
(0.31)\end{array}$ \\
\hline Top x GLB & & & & $\begin{array}{c}-2.35^{* * *} \\
(0.35)\end{array}$ & $\begin{array}{c}-1.98^{* * *} \\
(0.34)\end{array}$ & $\begin{array}{c}-1.40^{* * *} \\
(0.20)\end{array}$ & $\begin{array}{c}-1.34^{* * *} \\
(0.19)\end{array}$ \\
\hline Top x Crisis & & & & $\begin{array}{c}-1.91^{* * *} \\
(0.43)\end{array}$ & $\begin{array}{c}-1.55^{* * *} \\
(0.39)\end{array}$ & $\begin{array}{c}-1.52^{* * *} \\
(0.22)\end{array}$ & $\begin{array}{c}-1.28^{* * *} \\
(0.22)\end{array}$ \\
\hline Top x SCAP & & & & $\begin{array}{c}-2.60^{* * *} \\
(0.45)\end{array}$ & $\begin{array}{c}-2.41^{* * *} \\
(0.41)\end{array}$ & $\begin{array}{c}-1.88^{* * *} \\
(0.26)\end{array}$ & $\begin{array}{c}-1.63^{* * *} \\
(0.27)\end{array}$ \\
\hline Top x Dodd-Frank & & & & $\begin{array}{c}-2.31^{* * *} \\
(0.40)\end{array}$ & $\begin{array}{c}-2.22^{* * *} \\
(0.38)\end{array}$ & $\begin{array}{c}-1.93^{* * *} \\
(0.22)\end{array}$ & $\begin{array}{c}-1.90^{* * *} \\
(0.23)\end{array}$ \\
\hline Bank x Top x GLB & & & & $\begin{array}{l}1.16 \\
(0.72)\end{array}$ & $\begin{array}{c}1.23^{* * *} \\
(0.37)\end{array}$ & $\begin{array}{c}0.97^{* * *} \\
(0.31)\end{array}$ & $\begin{array}{l}0.48^{* *} \\
(0.22)\end{array}$ \\
\hline Bank x Top x Crisis & & & & $\begin{array}{c}0.87 \\
(1.14)\end{array}$ & $\begin{array}{l}0.80^{*} \\
(0.47)\end{array}$ & $\begin{array}{l}1.36^{* * *} \\
(0.41)\end{array}$ & $\begin{array}{l}0.54^{* *} \\
(0.27)\end{array}$ \\
\hline Bank x Top x SCAP & & & & $\begin{array}{l}1.49 \\
(1.31)\end{array}$ & $\begin{array}{c}1.57^{* * *} \\
(0.51)\end{array}$ & $\begin{array}{c}2.03^{* * *} \\
(0.56)\end{array}$ & $\begin{array}{l}0.78^{* *} \\
(0.37)\end{array}$ \\
\hline Bank x Top x Dodd-Frank & & & & $\begin{array}{l}1.63^{* *} \\
(0.75)\end{array}$ & $\begin{array}{c}1.31^{* * *} \\
(0.43)\end{array}$ & $\begin{array}{c}1.87^{* * *} \\
(0.45)\end{array}$ & $\begin{array}{l}0.59^{* *} \\
(0.28) \\
\end{array}$ \\
\hline Observations & 649688 & 649688 & 649606 & 649688 & 649606 & 649688 & 649606 \\
\hline Adjusted $R^{2}$ & 0.019 & 0.231 & 0.667 & 0.268 & 0.675 & 0.388 & 0.693 \\
\hline Fixed Effects & No & No & Yes & No & Yes & No & Yes \\
\hline Weighting & VW & VW & VW & VW & VW & $\mathrm{EW}$ & $\mathrm{EW}$ \\
\hline Sample & All Firms & All Firms & All Firms & All Firms & All Firms & All Firms & All Firms \\
\hline
\end{tabular}


Figure 1: The CAPM Cost of Capital for Banks

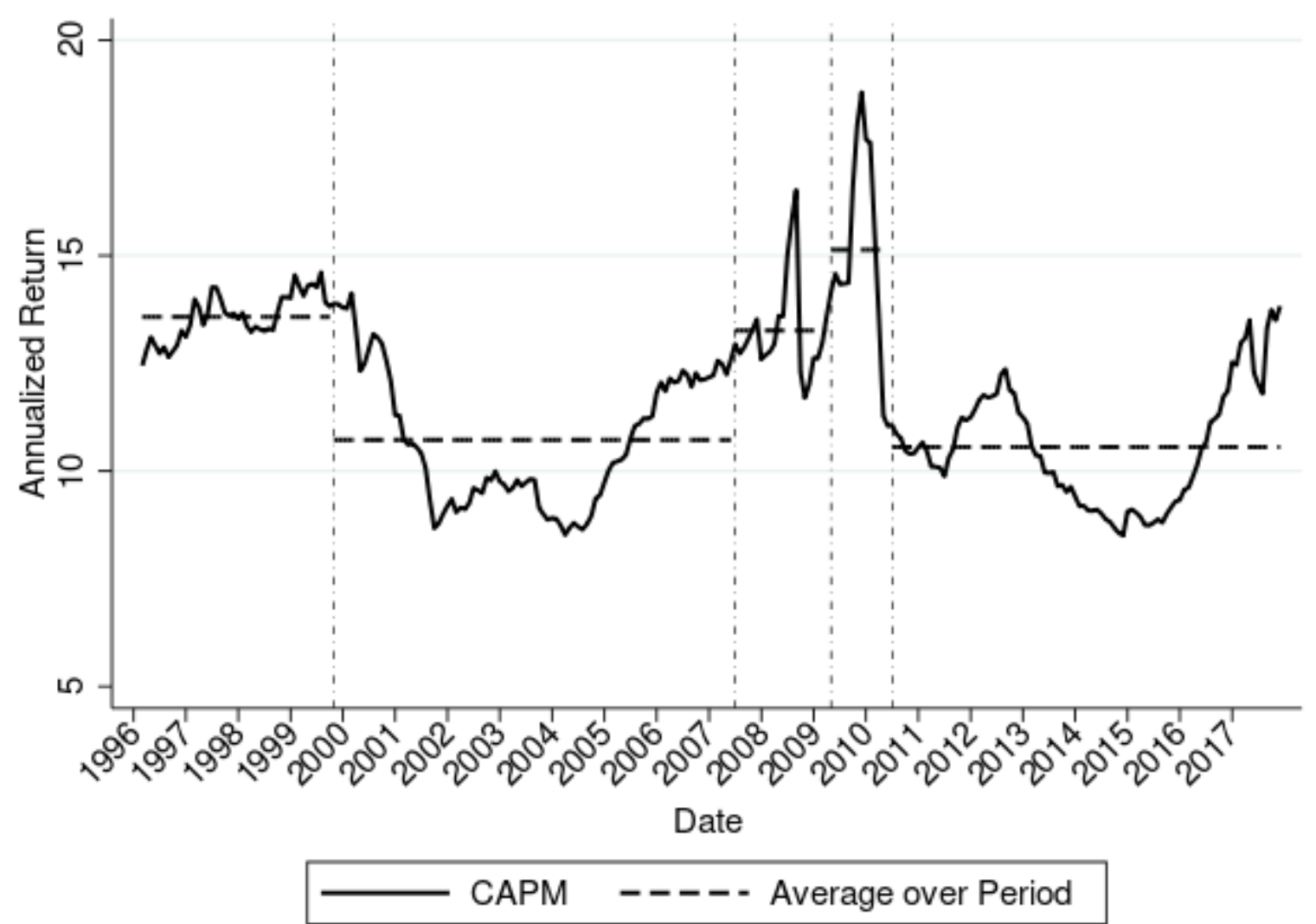

This figure plots the CAPM cost of capital for banks in the CRSP-Compustat universe valueweighted by market capitalization from March 1996 to December 2017. The cost of capital is estimated for each bank as $\mathrm{CAPM}_{i t}=R f_{t}+\beta_{i t} \cdot \mu_{r m r f}$ where $R f_{t}$ is the three-month Treasury bill rate, $\beta_{i t}$ is a time-varying beta from rolling one-year regressions of daily firm level excess returns onto CRSP value-weighted excess returns, and $\mu_{r m r f}=8 \%$ is a constant equity risk premium equal to the average CRSP value-weighted return from 1926 to 2017. 
Figure 2: The CAPM Cost of Capital for Banks versus Lending Supply

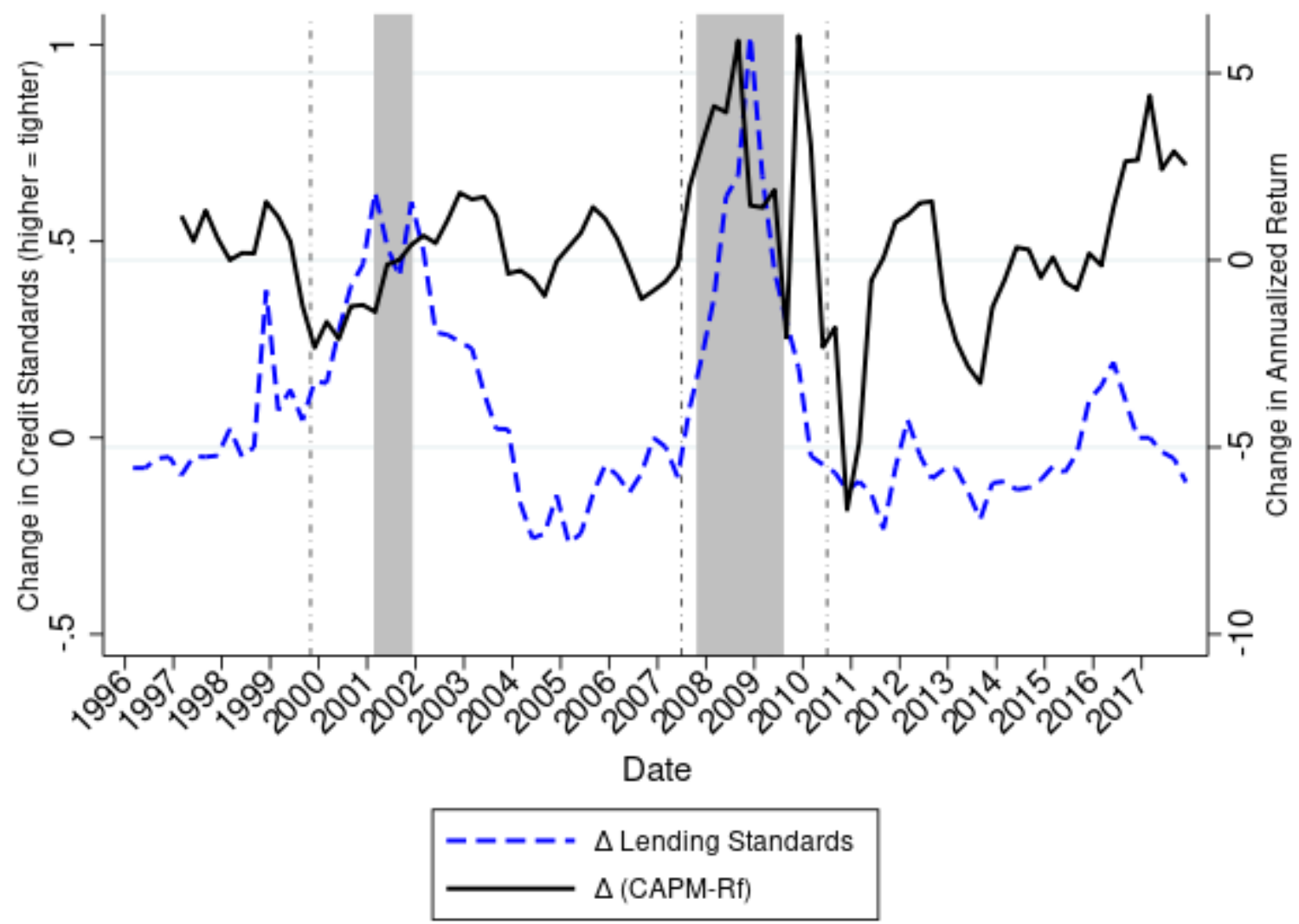

This figure plots the quarterly change in credit standards for large and middle-market firms (Std$\mathrm{LM}$ ) in the SLOOS against the one-year change in the CAPM risk premium, $\mathrm{CAPM}_{i t}-\mathrm{Rf}_{t}$, averaged across banks in the SLOOS from March 1996 to December 2017. The changes in credit standards are $29 \%$ [1.82] correlated with the change in the CAPM risk premium in the aggregate time-series, where significance is measured with a Newey-West $t$-statistic in brackets that is computed with 4 quarterly lags. Gray bars indicate NBER recession shading. 
Figure 3: The CAPM Cost of Capital for Banks and Top Banks Compared to Others

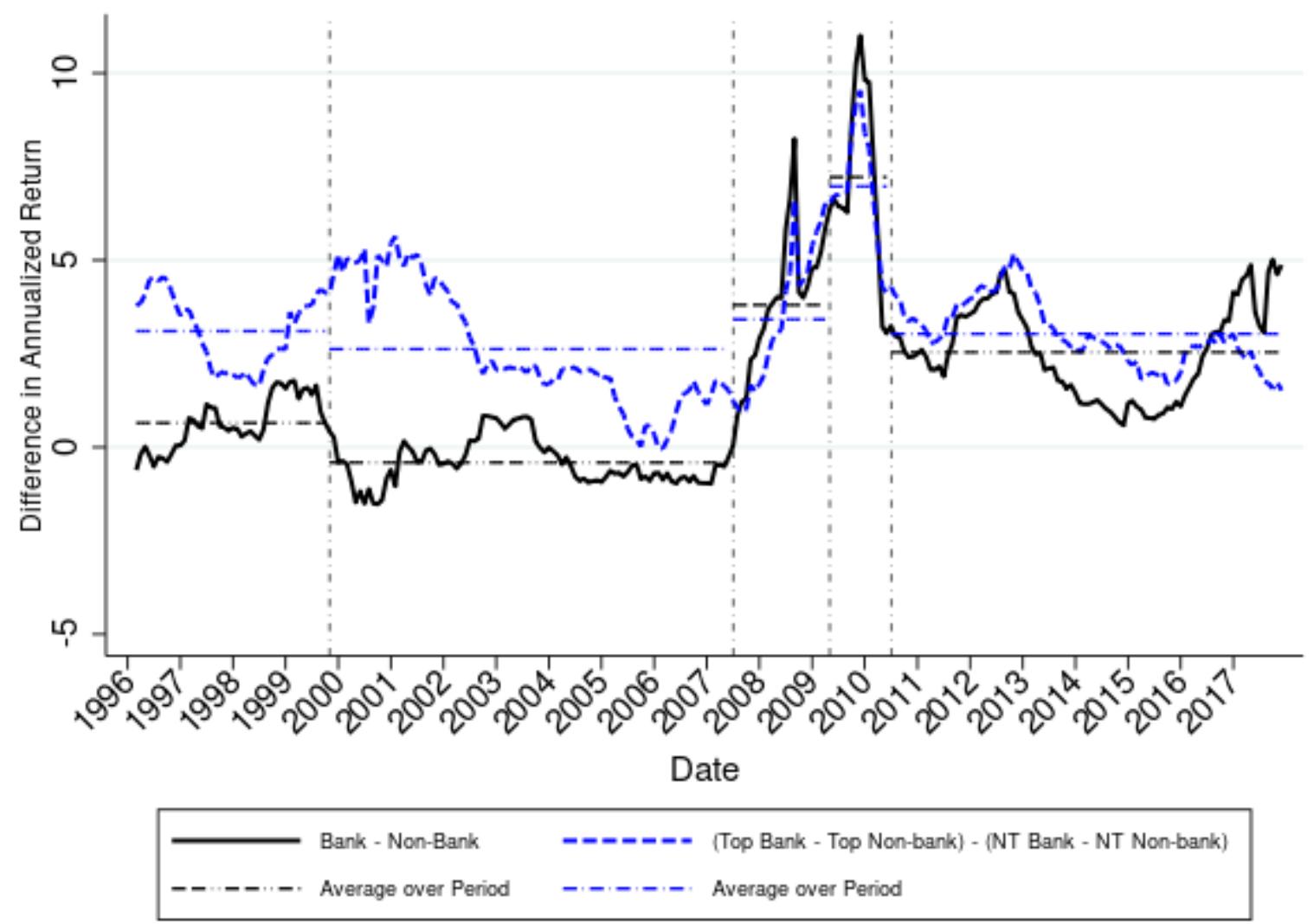

This figure plots the difference in the CAPM cost of capital for banks and top banks relative to other firms in the CRSP-Compustat universe value-weighted by market capitalization from March 1996 to December 2017. The dashed lines plot the average differences across subperiods. 
Figure 4: The CAPM Cost of Capital for the Largest Banks

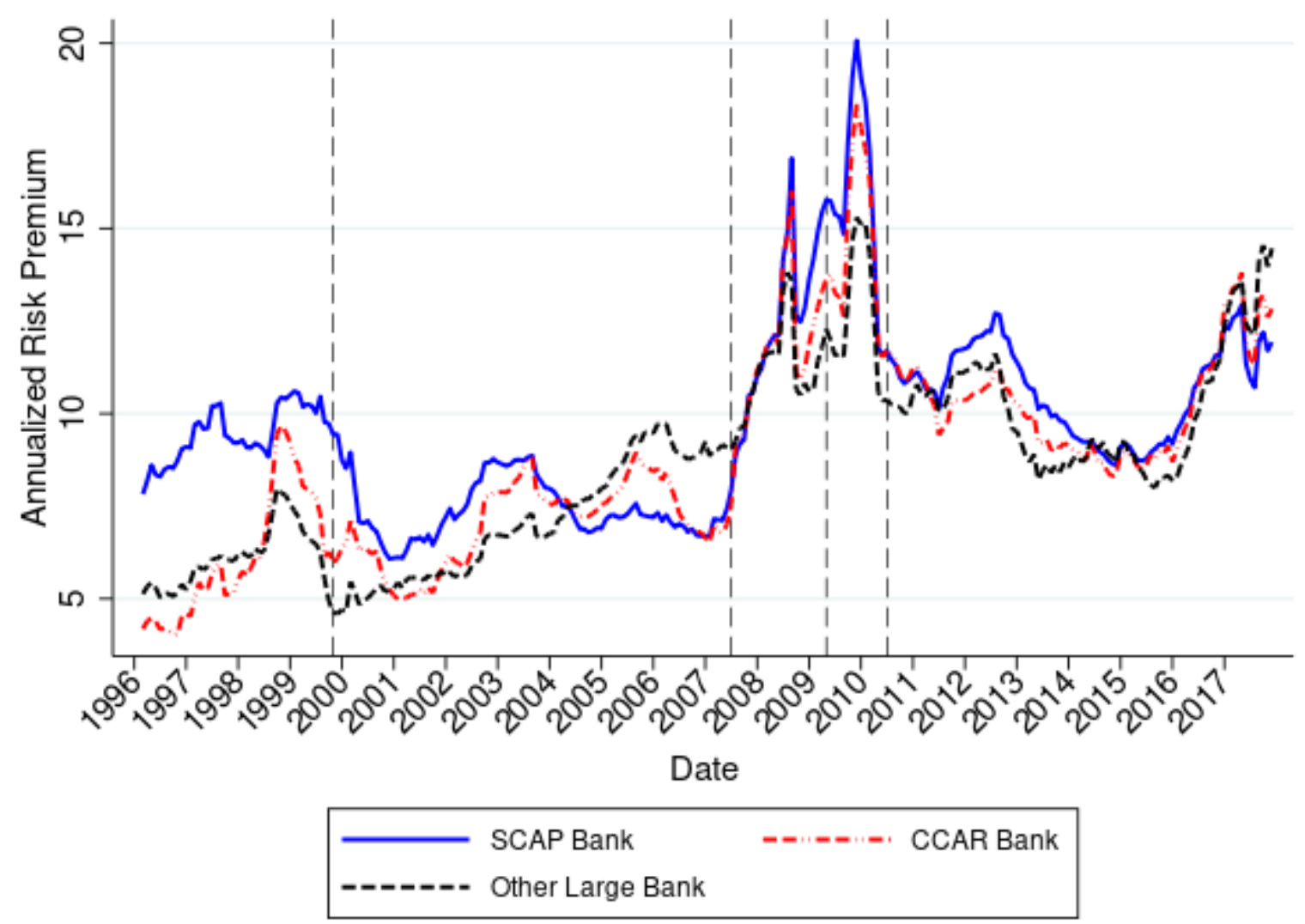

This figure plots the CAPM risk premium, $\mathrm{CAPM}_{i t}-\mathrm{Rf}_{t}$, for the $S C A P, C C A R$, and other Top 90 largest banks by assets in the CRSP-Compustat universe as an equal-weighted average from March 1996 to December 2017. Table 7 analyzes the cost of capital for these banks to study the impact of stress testing. 
Figure 5: Alternative Cost of Capital Estimates for Banks
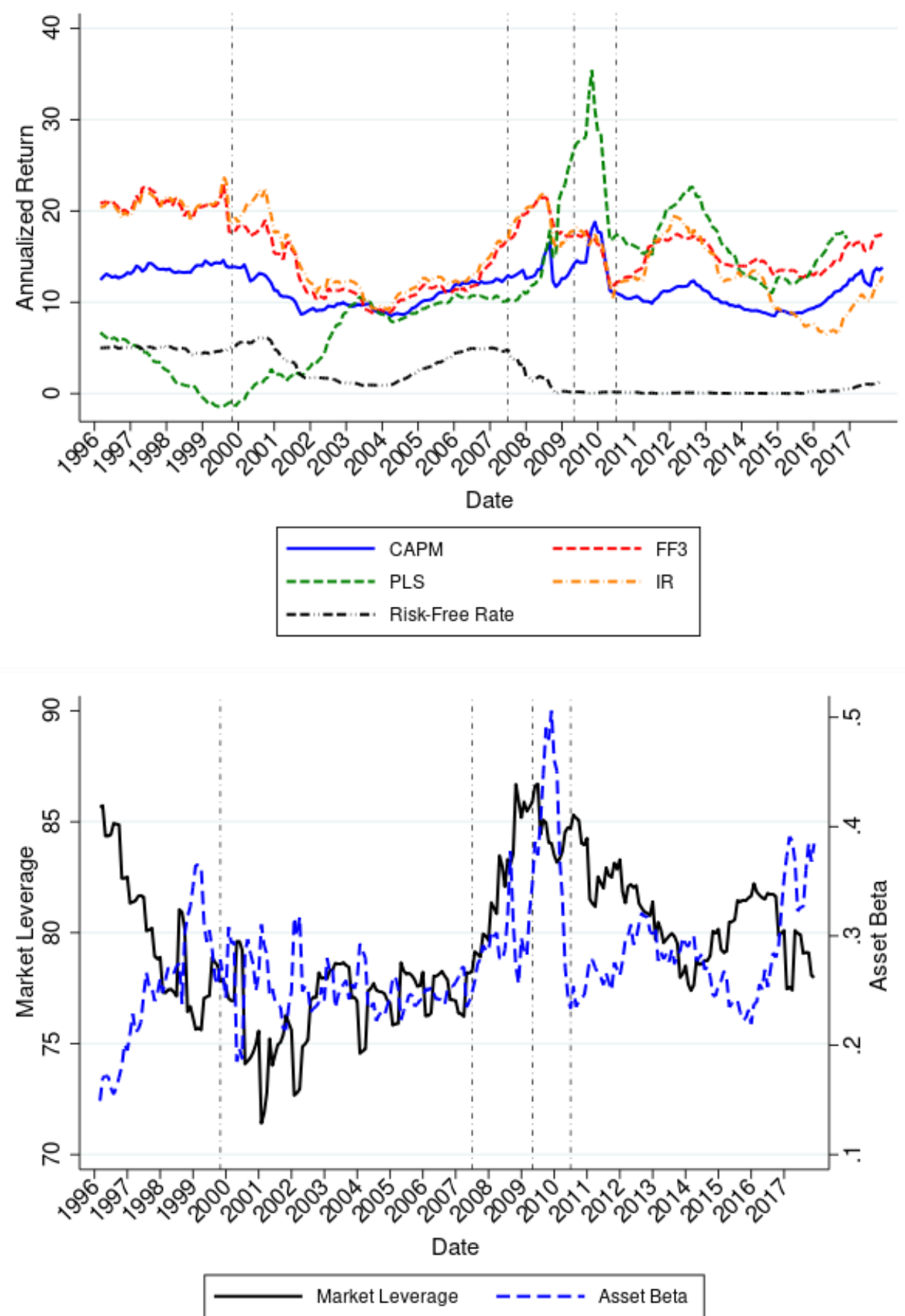

The top figure plots the alternative cost of capital estimates in the CAPM, FF3, IR, and PLS models. The bottom figure plots asset beta against market leverage. The results are value-weighted by market capitalization for banks in the CRSP-Compustat universe from March 1996 to December 2017, except for the PLS model which is available until 2016. 


\section{Appendix:}

Evaluating Regulatory Reform: Banks' Cost of Capital and Lending

Anna Kovner and Peter Van Tassel

July 2020 


\section{A Appendix}

\section{A.1 Alternative beta estimation methods}

In addition to exploring cost of capital measures from different models, we also check the robustness of our findings by varying the method for estimating the time-varying CAPM betas. Table A.3 summarizes these results by reporting value-weighted difference-in-difference regressions for banks relative to other industries with firm fixed effects (the same specification as column (3) in Tables 4 and 5). The first column (1) repeats the baseline approach which estimates betas with daily returns over a lagged one-year window. The second column (2) estimates betas with weekly overlapping returns over a lagged one-year window. The third column (3) follows the betting-against-beta approach from Frazzini and Pedersen (2014). The fourth column (4) follows Ang and Kristensen (2012) to estimate centered betas from rolling Gaussian kernel-weighted regressions with an optimal bandwidth parameter that is selected for daily returns. The subsequent columns (5-8) are analogous for the triple-difference regressions for the largest banks.

The different approaches are motivated by the following observations. In the absence of microstructure noise, estimates from daily returns should be preferred to weekly returns as the accuracy of covariance estimation is increasing in the sampling frequency (Merton 1980). However, in the presence of noise such as nonsynchronous trading, zooming out to a lower frequency may add robustness for correlation estimation. The betting-against-beta approach balances these observations by estimating volatility from daily log-returns over a one-year horizon and the correlation with the market from overlapping three-day log-returns over a longer, five-year horizon. The Ang and Kristensen (2012) method selects the optimal bandwidth to balance the bias-variance tradeoff for estimating a time-varying parameter using a data driven approach. ${ }^{22}$

Despite the different estimation methods, the empirical results are broadly similar. In columns (1-3) there is a decline in the CAPM cost of capital by around $3.75 \%$ to $4.5 \%$ between the SCAP and Dodd-Frank periods and an increase of around $1.75 \%$ to $2.5 \%$ between the Basel I and Dodd-Frank periods. The AK estimates in column (4) are slightly different from the other measures as they reflect centered, kernel-based betas rather than lagged betas.

\footnotetext{
${ }^{22}$ The optimal bandwidth balances the bias-variance trade-off in estimating the time-varying betas. It is estimated from a first-stage regression using a uniform one-sided kernel with 252 days of lagged data (the baseline estimates). The distribution of optimal bandwidths for the second-stage regressions has a 1.96 z-score for the Gaussian kernel at .47, .88, 1.01, 1.12, and 1.48 years for the 1st, 25th, 50th, 75th, and 99th percentiles respectively. As a result, most of the weight for the kernel regressions falls within one-year of the current date. In rare cases where the $1.96 \mathrm{z}$-score is less than 3-months, we truncate the optimal bandwidth to ensure that at least 6 -monthns of data fall within $95 \%$ of the mass for the Gaussian kernel. The truncation impacts less than $.01 \%$ of observations.
} 
This approach shifts and smooths some of the differential increase in the cost of capital for banks over time. For example, in column (4), the cost of capital is higher during the Crisis period, but there is still a decline of $2.5 \%$ between the SCAP and Dodd-Frank periods and an increase of $2.5 \%$ between the Basel I and Dodd-Frank periods. Similar results hold for the largest banks in columns (5-8). Compared to the standard errors of the estimates, most of the differences across estimation methods are not statistically significant indicating that our results are not driven by the method used for estimating the time-varying CAPM betas.

\section{A.2 Alternative bank sample}

To understand the robustness of our results to the definition of banks, Table A.4 reports the main difference-in-differences regressions defining banks as those firms whose two-digit SIC code is 60 (depository institutions). These regressions drop firms that were previously identified as banks but had SIC codes that did not begin with 60, since these firms are also subject to changes in bank regulation and thus do not belong in the comparison group. Results are generally similar to those presented in the paper, suggesting that the results are not sensitive to the definition of banks and that the changes to banks' cost of capital are not being driven solely by changes to the sample of regulated banks.

\section{A.3 Alternative definitions of regulatory breaks}

In addition to varying our regulatory time periods by a few months, we experiment with different time series breaks. Because the SCAP was a one-time stress test rather than a regulatory change, Table A.6 reports the results combining the Crisis and SCAP periods into a single Crisis period. Using these definitions, specifications (1) and (2) indicate that banks differential cost of capital declined by approximately $2.5 \%$ from the combined Crisis period to the Dodd-Frank period, a result that remains economically and statistically significant. In comparison, specifications (2) and (3) in Table 4 feature a significant decline of $4.5 \%$ basis points from SCAP to Dodd-Frank for banks with a smaller decline from the Crisis to DoddFrank. Taken together these results reflect how banks CAPM betas increased significantly during the SCAP period from May 2009 to June 2010. This timing is in part a feature of our estimation approach that uses rolling one-year regressions with lagged data to estimate betas, indicating that bank betas were increasing the most during the fall of the financial crisis and in the ensuing months. Similarly, there continues to be a differential decline in the cost of capital for the very largest banks from the combined Crisis period to Dodd-Frank but with a smaller magnitude than before. 


\section{A.4 Parallel trends}

This section examines pre-trends in the different comparison groups around the regulatory time period breaks. A key assumption underlying difference-in-differences analysis as a quasiexperimental research design for identifying causal effects is that the treatment and control groups would have behaved similarly on average in the absence of the treatment effect. In dynamic panel settings where the outcome variable is observed prior to the treatment effect, empirical studies often test the parallel trends assumption by plotting the outcome variable in the pre-period for both the treatment and control groups. Similar trends in the pre-period provide evidence that the control group can serve as a valid counterfactual for the treatment group after the treatment effect. One difference in our setting compared to typical difference-in-differences designs is that we have multiple regulatory break dates or treatment effects over the twenty-year sample period. Ideally one would like to document parallel trends leading into each of the break dates and divergence thereafter. To that end, we report both the value-weighted cost of capital estimates over the full sample period to illustrate the time-series correlation between the treatment and control groups and we also zoom in around the break dates with relatively short windows to avoid overlap across the periods and to test for parallel trends leading up to the regulatory changes or regime shifts.

Figures A.1 and A.2 investigate the parallel trends assumption by comparing banks to non-banks and banks to non-bank financials around the regulatory time period breaks. In each figure, the top plot reports the value-weighted CAPM cost of capital for the treatment and control groups over the full 1996 to 2017 sample period. The bottom plots zoom in around the regulatory time period breaks and report treatment $\mathrm{x}$ time period interaction coefficients from panel regressions that measure the differential change for the treated group (banks) in a six-month window $(h=6)$ around the break dates $\tau_{j}$ for $j=\{\mathrm{GLB}$, Crisis, SCAP, Dodd-Frank\},

$$
\mathrm{CAPM}_{i t}-\mathrm{Rf}_{t}=\alpha_{i}+\tau_{t}+\sum_{t=\tau_{j}-h}^{\tau_{j}+h} \beta_{i t} \cdot \text { Treat }_{i t} \cdot \text { Period }_{t}+e_{i t} .
$$

The coefficients are reported relative to the month prior to the time period break. ${ }^{23}$ If the parallel trends assumption is met, we would expect to find no significant $\beta_{i t}$ coefficients in the pre-period and only detect an effect after banking regulation changed.

Generally, the time-series plots are consistent with the discussion in the paper. The best identified comparisons are those between banks and non-bank financials. ${ }^{24}$ In particular,

\footnotetext{
${ }^{23}$ The results are similar if we include leverage or bank characteristics as control variables.

${ }^{24}$ Synthetic control analysis from Abadie et al. (2010) delivers similar results (unreported available upon
} 
the correlation of the value-weighted CAPM cost of capital is $75 \%$ for banks and non-bank financials. This strong positive correlation suggests that non-bank financials are relevant control groups for providing counterfactual analysis for banks. Moreover, for this control group, the estimated Bank x time period interaction coefficients are not significantly different from zero in the months leading up to the passage of the GLB Act. Notably, this pre-period corresponds to the Basel I period to which all of the treatment $\mathrm{x}$ time period interaction coefficients are compared in the tables in the paper.

However, we note that the regression analysis is not as supportive of the parallel trends assumption for the other time periods. This may be in part due to the lack of an ideal control group for the largest banks but also due to regulation responding to changes that differentially affect banks, imprecision in defining the break dates, and the slow-moving nature of the cost of capital estimates. For example, prior to the passage of the DoddFrank Act, it was precisely the divergence of the systemic risk of the largest banks during the financial crisis that was in part the cause of the Dodd-Frank regulation, leading to mechanical pre-trends for the SCAP and DFA periods. In addition, since financial markets are forward looking, one could argue that the treatment period for the DFA period should start a few months before the passage of the law. While the baseline regression results are similar if we vary the time periods within a few months, due to the relatively long horizon of the different periods, changing the break dates may have a larger impact on the parallel trend tests that zoom in around the break dates. For example, Figure A.3 shows that the parallel trend assumption holds more closely for the DFA period if the start date is moved back from July 2010 to March 2010.

Rather than try to reverse engineer what break dates are best from a pre-trend perspective, we instead report the results based on dates that are defined by changes in legislation or significant regime shifts (i.e. the financial crisis) that were selected before we tested for parallel trends. $^{25}$

request). We select synthetic controls by comparing banks to 12 Fama-French industry portfolios and by comparing Top banks to 10 portfolios of non-Top banks sorted by asset size (the synthetic control method requires us to aggregate to the portfolio level for a balanced panel which abstracts from the changing panel composition). The synthetic control method mechanically chooses a weighted average among potential control groups (the synthetic control) to match cost of capital estimates and firm characteristics of the treatment and synthetic control groups in the pre-period. We find that the synthetic control analysis typically identifies the "ad-hoc" control group from the paper. For example, at the industry level, the synthetic control for banks is typically non-bank financials.

${ }^{25}$ While a common diagnostic tool in practice, recent studies have shown that pre-testing for parallel trends can lead to biased inference and overstated confidence intervals (Roth (2019), Freyaldenhoven et al. (2019)). 


\section{A.5 Additional bank characteristic analysis}

Table A.7 extends the analysis of bank characteristics by decomposing RWA into its component parts to better understand which types of risks are driving changes in the cost of capital over time. We examine the relationship between the cost of capital and securities (including cash, available-for-sale and held-to-maturity securities, and securities purchased under agreements to resell), loans, trading assets, loan commitments, and total derivatives. We first include all of the variables individually and then include them all jointly in the final specification. The results indicate that banks' CAPM cost of capital is decreasing in securities, loans, and loan commitments in the multivariate specification (7). As before, we continue to estimate a significant decline in banks' CAPM cost of capital from the SCAP to the Dodd-Frank period. Finally, Table A.8 extends the analysis to the Top banks. In these regressions we include additional interaction terms between bank characteristics and the Top dummy variable to see which characteristics drive the Top banks cost of capital over time. In these regressions we continue to find a decline in the largest banks' cost of capital by about 3\% to $4 \%$ from the SCAP to the Dodd-Frank period across specifications, indicating that characteristics do not explain the observed changes in the Top banks cost of capital over the sample period. 
Table A.1: Federal Reserve Mnemonics for Bank Characteristic Variables

This table reports the mnemonics for the variables used to define the bank characteristics.

\begin{tabular}{l|l}
\hline Variable & Federal Reserve Mnemonic \\
\hline Tier 1 Risk Based Capital & BHCK8274 (1996-2013) \\
& BHCA8274 $(2014-2017)$ \\
\hline Risk-Weighted Assets & BHCKA223 $(1996-2013)$ \\
& BHCAA223 $(2014-2017)$ \\
\hline Non-Interest Income & BHCK4079 \\
\hline Net Interest Income & BHCK4074 \\
\hline Total Assets & BHCK2170 \\
\hline Total Liabilities & BHCK2948 + BHCK3282 - BHCK3000 (1996) \\
& BHCK2948 - BHCK3000 (1997-2000) \\
& BHCK2948 $(2001-2017)$ \\
\hline Cash & BHCK0081 + BHCK0395 + BHCK0397 \\
\hline Federal Fund Repos & BHCK0276 + BHCK0277 (1996) \\
& BHCK1350 $(1997-2001)$ \\
\hline AFS + HTM Securities & BHDMB987 + BHCK989 $(2002-2017)$ \\
\hline Unused Loan Commitments & BHCK3814 + BHCK3816 + BHCK6550 + BHCK3815 + \\
& BHCK3817 + BHCK3818 (1996-2009) \\
& BHCK3814 + BHCKJ455 + BHCKJ456 + BHCKJ457 + \\
& BHCKJ458 + BHCKJ459 + BHCK3816 + \\
& BHCK3817 + BHCK6550 (2010-2017) \\
\hline Trading Assets & BHCK3545 \\
\hline Derivatives & BHCK8765 + BHCK3433 + BHCKA126 + BHCKA127 + \\
& BHCK8723 + BHCK8724 + BHCK8725 + \\
\hline
\end{tabular}




\section{Table A.2: Summary Statistics by Period}

This table reports the value-weighted average cost of capital measures and bank characteristics by time period. Panel A reports the weighted average for the cost of capital measures separating banks and non-banks. Panel B reports the weighted average for the bank characteristic variables. The sample period is March 1996 to December 2017.

\begin{tabular}{|c|c|c|c|c|c|}
\hline \multicolumn{6}{|c|}{ Panel A: Cost of Capital Measures Over Time } \\
\hline Period & Basel I & GLB & Crisis & SCAP & DFA \\
\hline \multicolumn{6}{|l|}{ Panel A.I: Banks } \\
\hline CAPM & 13.59 & 10.57 & 13.21 & 15.12 & 10.58 \\
\hline CAPM - Rf & 8.71 & 7.57 & 11.33 & 14.99 & 10.35 \\
\hline CAPM Beta & 1.09 & 0.95 & 1.42 & 1.88 & 1.30 \\
\hline FF3 - Rf & 15.91 & 9.36 & 17.06 & 15.67 & 14.63 \\
\hline IR-Rf & 15.98 & 10.45 & 17.04 & 15.79 & 11.89 \\
\hline PLS-Rf & -2.31 & 4.18 & 12.55 & 26.37 & 15.90 \\
\hline Log(Beta) & -0.02 & -0.12 & 0.29 & 0.58 & 0.23 \\
\hline Asset Beta & 0.25 & 0.25 & 0.29 & 0.40 & 0.28 \\
\hline WACC-Rf & -0.00 & 0.92 & 2.33 & 3.08 & 2.24 \\
\hline Leverage & 80.00 & 76.64 & 82.26 & 84.58 & 80.70 \\
\hline \multicolumn{6}{|l|}{ Panel A.II: Non-Banks } \\
\hline CAPM & 12.93 & 11.16 & 9.44 & 7.91 & 8.02 \\
\hline CAPM - Rf & 8.06 & 7.95 & 7.71 & 7.78 & 7.80 \\
\hline CAPM Beta & 1.01 & 1.00 & 0.97 & 0.98 & 0.98 \\
\hline FF3 - Rf & 6.97 & 7.79 & 7.11 & 7.73 & 7.39 \\
\hline IR-Rf & 6.97 & 7.65 & 7.25 & 7.85 & 7.67 \\
\hline PLS-Rf & -1.95 & 3.55 & 8.57 & 13.68 & 12.25 \\
\hline $\log ($ Beta $)$ & -0.10 & -0.19 & -0.10 & -0.12 & -0.09 \\
\hline Asset Beta & 0.85 & 0.82 & 0.81 & 0.82 & 0.84 \\
\hline WACC-Rf & 5.94 & 5.86 & 6.35 & 6.49 & 6.63 \\
\hline Leverage & 19.22 & 19.40 & 20.54 & 21.25 & 19.33 \\
\hline \multicolumn{6}{|c|}{ Panel B: Bank Characteristics Over Time } \\
\hline Period & Basel I & GLB & Crisis & SCAP & DFA \\
\hline Tier 1 Ratio & 9.22 & 9.78 & 9.51 & 12.08 & 13.46 \\
\hline Core Deposits & 41.49 & 36.71 & 34.65 & 34.60 & 41.87 \\
\hline Liquidity Coverage & 57.63 & 54.01 & 53.13 & 61.03 & 69.42 \\
\hline Non-Interest Income & 41.30 & 48.35 & 44.63 & 53.56 & 48.92 \\
\hline Risk-Weighted Assets & 79.05 & 73.99 & 72.05 & 67.37 & 66.84 \\
\hline Cash + FF + Sec. & 26.61 & 28.30 & 26.65 & 32.84 & 34.34 \\
\hline Loans & 60.68 & 52.82 & 51.16 & 44.02 & 46.81 \\
\hline Commitments & 51.68 & 49.96 & 52.07 & 40.00 & 38.23 \\
\hline Trading Assets & 4.39 & 6.16 & 6.46 & 7.35 & 6.38 \\
\hline Derivatives & 300.09 & 439.47 & 490.47 & 544.10 & 451.02 \\
\hline
\end{tabular}


Table A.3: Cost of Capital Estimates for Banks with Alternative Betas

This table reports differential CAPM cost of capital for banks and for the largest banks over time using different methods to estimate time-varying betas. The beta estimates are from the baseline approach with daily returns, weekly returns (Wk), the Frazzini and Pedersen (2014) betting-against-beta approach (BAB), and the Ang and Kristensen (2012) optimal-kernel based method (AK). The regression specifications are the same as column (3) in Tables 4 and 5. Standard errors are clustered by firm and month with ${ }^{*},{ }^{* *},{ }^{* * *}$ indicating significance at the $10 \%, 5 \%$, and $1 \%$ levels.

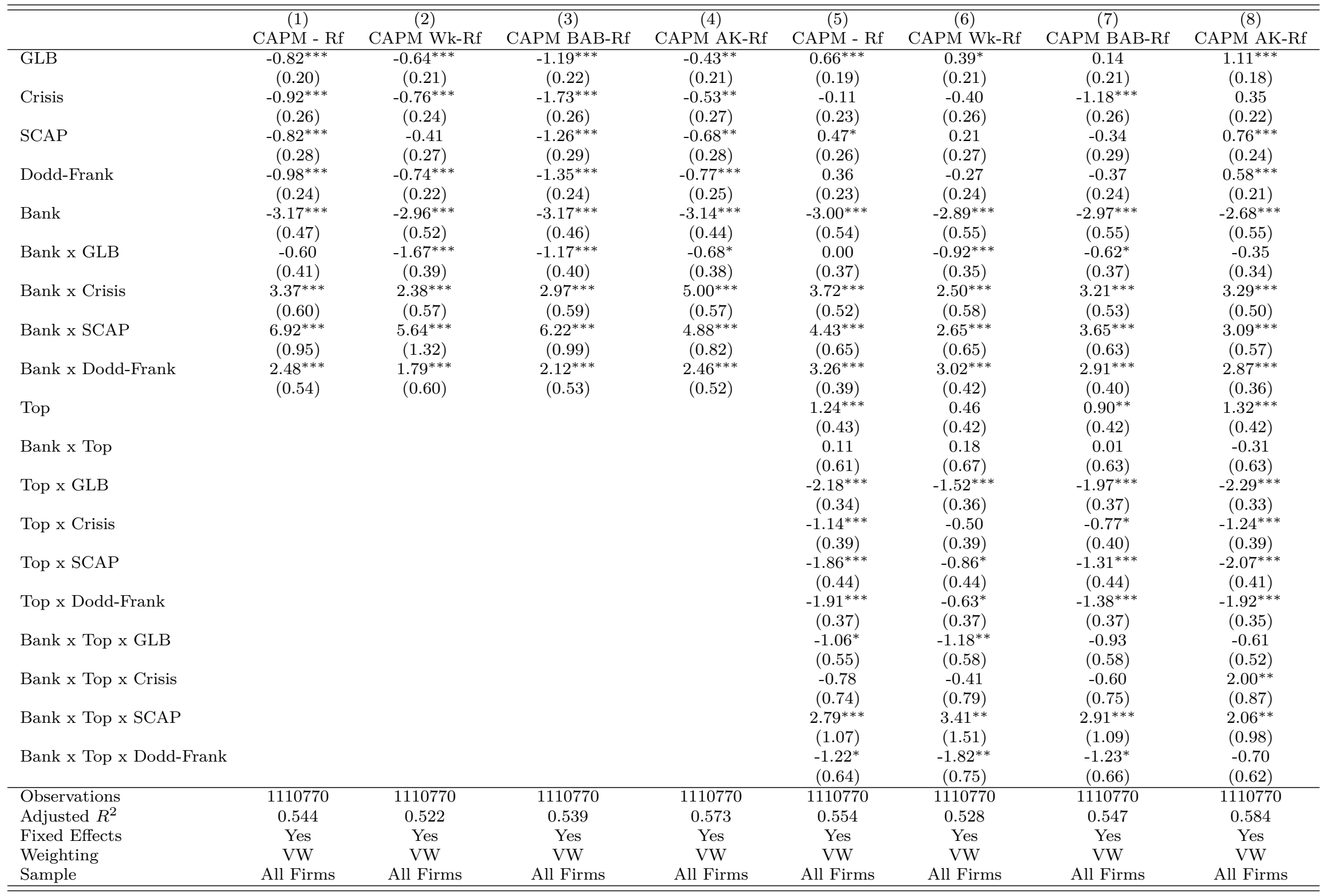


Table A.4: Cost of Capital Estimates for Banks with Alternative Bank Sample

This table reports the differential cost of capital for banks over time relative to other industries by regressing the CAPM cost of capital onto a constant and time period dummies along with indicator and interaction terms for banks. This table uses an alternative definition of banks defined as SIC code 60 firms and removing from the panel banks in the original sample that don't have SIC code 60. Standard errors are clustered by firm and month with ${ }^{*},{ }^{* *},{ }^{* *}$ indicating significance at the $10 \%, 5 \%$, and $1 \%$ levels.

\begin{tabular}{|c|c|c|c|c|c|c|c|c|}
\hline & $\begin{array}{c}(1) \\
\text { CAPM - Rf }\end{array}$ & $\begin{array}{c}(2) \\
\text { CAPM - Rf }\end{array}$ & $\begin{array}{c}(3) \\
\text { CAPM - Rf }\end{array}$ & $\begin{array}{c}(4) \\
\text { CAPM - Rf }\end{array}$ & $\begin{array}{c}(5) \\
\text { CAPM - Rf }\end{array}$ & $\begin{array}{c}(6) \\
\text { CAPM - Rf }\end{array}$ & $\begin{array}{c}(7) \\
\text { CAPM - Rf }\end{array}$ & $\begin{array}{c}(8) \\
\text { CAPM - Rf }\end{array}$ \\
\hline GLB & $\begin{array}{l}-0.10 \\
(0.20)\end{array}$ & $\begin{array}{c}-0.82^{* * *} \\
(0.20)\end{array}$ & $\begin{array}{c}-1.70^{* * *} \\
(0.47)\end{array}$ & $\begin{array}{c}0.84^{* * *} \\
(0.20)\end{array}$ & $\begin{array}{c}1.54^{* * *} \\
(0.23)\end{array}$ & $\begin{array}{c}0.66^{* * *} \\
(0.19)\end{array}$ & $\begin{array}{l}-0.15 \\
(0.27)\end{array}$ & $\begin{array}{c}0.91^{* * *} \\
(0.21)\end{array}$ \\
\hline Crisis & $\begin{array}{l}-0.36 \\
(0.22)\end{array}$ & $\begin{array}{c}-0.92^{* * *} \\
(0.26)\end{array}$ & $\begin{array}{l}1.05^{* *} \\
(0.45)\end{array}$ & $\begin{array}{c}1.05^{* * *} \\
(0.16)\end{array}$ & $\begin{array}{l}0.59^{* *} \\
(0.23)\end{array}$ & $\begin{array}{l}-0.12 \\
(0.23)\end{array}$ & $\begin{array}{c}1.32^{* * *} \\
(0.46)\end{array}$ & $\begin{array}{c}1.06^{* * *} \\
(0.17)\end{array}$ \\
\hline SCAP & $\begin{array}{l}-0.28 \\
(0.25)\end{array}$ & $\begin{array}{c}-0.82^{* * *} \\
(0.29)\end{array}$ & $\begin{array}{c}2.78^{* * *} \\
(0.76)\end{array}$ & $\begin{array}{c}2.17^{* * *} \\
(0.20)\end{array}$ & $\begin{array}{c}1.28^{* * * *} \\
(0.26)\end{array}$ & $\begin{array}{l}0.50^{*} \\
(0.27)\end{array}$ & $\begin{array}{c}2.50^{* * *} \\
(0.53)\end{array}$ & $\begin{array}{c}2.18^{* * *} \\
(0.21)\end{array}$ \\
\hline Dodd-Frank & $\begin{array}{l}-0.27 \\
(0.22)\end{array}$ & $\begin{array}{c}-0.98^{* * *} \\
(0.25)\end{array}$ & $\begin{array}{c}0.09 \\
(0.47)\end{array}$ & $\begin{array}{c}2.14^{* * * *} \\
(0.16)\end{array}$ & $\begin{array}{c}1.23^{* * *} \\
(0.22)\end{array}$ & $\begin{array}{c}0.37 \\
(0.23)\end{array}$ & $\begin{array}{l}0.67^{*} \\
(0.35)\end{array}$ & $\begin{array}{c}2.24^{* * *} \\
(0.18)\end{array}$ \\
\hline Bank & $\begin{array}{c}0.52 \\
(0.37)\end{array}$ & $\begin{array}{l}-3.19 \\
(2.07)\end{array}$ & $\begin{array}{c}-10.66^{* * *} \\
(1.61)\end{array}$ & $\begin{array}{c}-2.23^{* * *} \\
(0.83)\end{array}$ & $\begin{array}{c}-1.20^{* * *} \\
(0.40)\end{array}$ & $\begin{array}{l}-3.35^{*} \\
(1.87)\end{array}$ & $\begin{array}{c}-10.57^{* * *} \\
(1.37)\end{array}$ & $\begin{array}{c}-2.19^{* * *} \\
(0.83)\end{array}$ \\
\hline Bank x GLB & $\begin{array}{c}-1.36^{* * *} \\
(0.40)\end{array}$ & $\begin{array}{l}-0.49 \\
(0.41)\end{array}$ & $\begin{array}{c}0.39 \\
(0.58)\end{array}$ & $\begin{array}{c}0.33 \\
(0.24)\end{array}$ & $\begin{array}{c}-1.36^{* * *} \\
(0.33)\end{array}$ & $\begin{array}{l}-0.21 \\
(0.34)\end{array}$ & $\begin{array}{l}0.59^{*} \\
(0.35)\end{array}$ & $\begin{array}{c}0.39 \\
(0.24)\end{array}$ \\
\hline Bank $x$ Crisis & $\begin{array}{c}2.74^{* * *} \\
(0.53)\end{array}$ & $\begin{array}{c}3.60^{* * *} \\
(0.58)\end{array}$ & $\begin{array}{c}1.63^{* * *} \\
(0.56)\end{array}$ & $\begin{array}{c}2.42^{* * *} \\
(0.30)\end{array}$ & $\begin{array}{c}1.88^{* * *} \\
(0.48)\end{array}$ & $\begin{array}{c}3.91^{* * * *} \\
(0.44)\end{array}$ & $\begin{array}{c}2.46^{* * *} \\
(0.56)\end{array}$ & $\begin{array}{c}2.45^{* * *} \\
(0.31)\end{array}$ \\
\hline Bank x SCAP & $\begin{array}{c}6.02^{* * * *} \\
(1.04)\end{array}$ & $\begin{array}{c}6.89^{* * *} \\
(1.05)\end{array}$ & $\begin{array}{c}3.30^{* * * *} \\
(1.14)\end{array}$ & $\begin{array}{c}2.27^{* * *} \\
(0.33)\end{array}$ & $\begin{array}{l}1.66^{* *} \\
(0.69)\end{array}$ & $\begin{array}{c}3.94^{* * *} \\
(0.69)\end{array}$ & $\begin{array}{l}1.93^{* *} \\
(0.79)\end{array}$ & $\begin{array}{c}2.23^{* * *} \\
(0.34)\end{array}$ \\
\hline Bank x Dodd-Frank & $\begin{array}{c}1.50^{* * * *} \\
(0.44)\end{array}$ & $\begin{array}{c}2.71^{* * *} \\
(0.62)\end{array}$ & $\begin{array}{l}1.64^{* *} \\
(0.72)\end{array}$ & $\begin{array}{c}1.72^{* * *} \\
(0.27)\end{array}$ & $\begin{array}{c}1.19^{* * *} \\
(0.45)\end{array}$ & $\begin{array}{c}3.29^{* * * *} \\
(0.39)\end{array}$ & $\begin{array}{c}2.98^{* * *} \\
(0.45)\end{array}$ & $\begin{array}{c}1.74^{* * *} \\
(0.27)\end{array}$ \\
\hline Top & & & & & $\begin{array}{c}0.46 \\
(0.31)\end{array}$ & $\begin{array}{c}1.25^{* * *} \\
(0.44)\end{array}$ & $\begin{array}{l}1.03 \\
(0.74)\end{array}$ & $\begin{array}{c}1.07^{* * *} \\
(0.26)\end{array}$ \\
\hline Bank x Top & & & & & $\begin{array}{c}3.02^{* * *} \\
(0.53)\end{array}$ & $\begin{array}{c}0.32 \\
(0.65)\end{array}$ & $\begin{array}{c}0.57 \\
(0.88)\end{array}$ & $\begin{array}{c}0.71 \\
(0.60)\end{array}$ \\
\hline Top x GLB & & & & & $\begin{array}{c}-2.55^{* * *} \\
(0.41)\end{array}$ & $\begin{array}{c}-2.19^{* * *} \\
(0.34)\end{array}$ & $\begin{array}{c}-2.91^{* * *} \\
(0.73)\end{array}$ & $\begin{array}{c}-1.22^{* * * *} \\
(0.25)\end{array}$ \\
\hline Top x Crisis & & & & & $\begin{array}{c}-1.46^{* * *} \\
(0.39)\end{array}$ & $\begin{array}{c}-1.15^{* * *} \\
(0.39)\end{array}$ & $\begin{array}{l}-0.16 \\
(0.73)\end{array}$ & $\begin{array}{l}-0.30 \\
(0.27)\end{array}$ \\
\hline Top x SCAP & & & & & $\begin{array}{c}-2.37^{* * *} \\
(0.42)\end{array}$ & $\begin{array}{c}-1.90^{* * * *} \\
(0.45)\end{array}$ & $\begin{array}{c}1.67 \\
(1.42)\end{array}$ & $\begin{array}{l}-0.42 \\
(0.35)\end{array}$ \\
\hline Top x Dodd-Frank & & & & & $\begin{array}{c}-2.29^{* * *} \\
(0.36)\end{array}$ & $\begin{array}{c}-1.93^{* * *} \\
(0.37)\end{array}$ & $\begin{array}{l}-0.58 \\
(0.86)\end{array}$ & $\begin{array}{c}-1.42^{* * *} \\
(0.28)\end{array}$ \\
\hline Bank x Top x GLB & & & & & $\begin{array}{l}-0.36 \\
(0.62)\end{array}$ & $\begin{array}{l}-0.68 \\
(0.55)\end{array}$ & $\begin{array}{c}0.05 \\
(0.84)\end{array}$ & $\begin{array}{c}-2.33^{* * *} \\
(0.40)\end{array}$ \\
\hline Bank $\mathrm{x}$ Top $\mathrm{x}$ Crisis & & & & & $\begin{array}{c}0.64 \\
(0.74)\end{array}$ & $\begin{array}{l}-0.72 \\
(0.67)\end{array}$ & $\begin{array}{c}-1.71^{* * *} \\
(0.86)\end{array}$ & $\begin{array}{l}-0.13 \\
(0.68)\end{array}$ \\
\hline Bank x Top x SCAP & & & & & $\begin{array}{c}5.59^{* * *} \\
(1.16)\end{array}$ & $\begin{array}{c}3.85^{* * * *} \\
(1.25)\end{array}$ & $\begin{array}{c}0.29 \\
(1.79)\end{array}$ & $\begin{array}{l}2.42^{* *} \\
(1.00)\end{array}$ \\
\hline Bank x Top x Dodd-Frank & & & & & $\begin{array}{c}0.08 \\
(0.69) \\
\end{array}$ & $\begin{array}{l}-1.12 \\
(0.69) \\
\end{array}$ & $\begin{array}{c}-2.46^{* *} \\
(1.04) \\
\end{array}$ & $\begin{array}{c}-1.55^{* * *} \\
(0.58) \\
\end{array}$ \\
\hline Observations & 1108439 & 1108374 & 220744 & 1108374 & 1108439 & 1108374 & 220744 & 1108374 \\
\hline Adjusted $R^{2}$ & 0.027 & 0.540 & 0.590 & 0.535 & 0.084 & 0.550 & 0.623 & 0.536 \\
\hline Fixed Effects & No & Yes & Yes & Yes & No & Yes & Yes & Yes \\
\hline Weighting & VW & VW & VW & EW & VW & VW & VW & EW \\
\hline Sample & All Firms & All Firms & Banks+NBF & All Firms & All Firms & All Firms & Banks+NBF & All Firms \\
\hline
\end{tabular}




\section{Table A.5: Predicting Future CAPM Betas with Current CAPM Betas}

This table reports regressions of future CAPM betas onto current CAPM betas. The results indicate that current betas predict future betas, or that high systematic risk today predicts high systematic risk in the future. Panels A-C vary the forecast horizon across sixmonths, twelve-months, and twenty-four months. The regressions include all firms (specifications 1-4) or a bank only panel (specifications 5-8). The different specifications show that the predictability is robust in the cross section and within firm by including time or firm fixed effects and include results that are value-weighted and equal-weighted. Standard errors are clustered by firm and month with *, ${ }^{* *}$, *** indicating significance at the 10\%, 5\%, and 1\% levels. The sample period is March 1996 to December 2017.

\begin{tabular}{|c|c|c|c|c|c|c|c|c|}
\hline & $(1)$ & $(2)$ & $(3)$ & $(4)$ & $(5)$ & $(6)$ & $(7)$ & $(8)$ \\
\hline \multicolumn{9}{|c|}{ Panel A: Six-month horizon, $\beta_{i, t+h}=\alpha+\theta \beta_{i t}+e_{i t}, h=6$} \\
\hline$\beta_{i t}$ & $\begin{array}{c}0.90^{* * *} \\
(0.02)\end{array}$ & $\begin{array}{c}0.76^{* * *} \\
(0.02)\end{array}$ & $\begin{array}{c}0.83^{* * *} \\
(0.01)\end{array}$ & $\begin{array}{c}0.68^{* * *} \\
(0.01)\end{array}$ & $\begin{array}{c}0.87^{* * *} \\
(0.02)\end{array}$ & $\begin{array}{c}0.76^{* * *} \\
(0.06)\end{array}$ & $\begin{array}{c}0.93^{* * *} \\
(0.01)\end{array}$ & $\begin{array}{c}0.79^{* * *} \\
(0.02)\end{array}$ \\
\hline Observations & 1040342 & 1040279 & 1040342 & 1040279 & 133666 & 133659 & 133666 & 133659 \\
\hline Adjusted $R^{2}$ & 0.789 & 0.799 & 0.735 & 0.744 & 0.856 & 0.690 & 0.822 & 0.837 \\
\hline \multicolumn{9}{|c|}{ Panel B: Twelve-month horizon, $\beta_{i, t+h}=\alpha+\theta \beta_{i t}+e_{i t}, h=12$} \\
\hline$\beta_{i t}$ & $\begin{array}{c}0.76^{* * *} \\
(0.02)\end{array}$ & $\begin{array}{c}0.48^{* * *} \\
(0.02)\end{array}$ & $\begin{array}{c}0.67^{* * *} \\
(0.01)\end{array}$ & $\begin{array}{c}0.36^{* * *} \\
(0.01)\end{array}$ & $\begin{array}{c}0.70^{* * *} \\
(0.02)\end{array}$ & $\begin{array}{c}0.49^{* * *} \\
(0.05)\end{array}$ & $\begin{array}{c}0.84^{* * *} \\
(0.01)\end{array}$ & $\begin{array}{c}0.56^{* * *} \\
(0.02)\end{array}$ \\
\hline rations & 972072 & 971944 & 972072 & 971944 & 125385 & 125377 & 125385 & 125377 \\
\hline Adjusted $R^{2}$ & 0.572 & 0.627 & 0.515 & 0.590 & 0.716 & 0.416 & 0.651 & 0.714 \\
\hline \multicolumn{9}{|c|}{ Panel C: Twenty-four-month horizon, $\beta_{i, t+h}=\alpha+\theta \beta_{i t}+e_{i t}, h=24$} \\
\hline$\beta_{i t}$ & $\begin{array}{c}0.62^{* * *} \\
(0.02)\end{array}$ & $\begin{array}{c}0.23^{* * *} \\
(0.02)\end{array}$ & $\begin{array}{c}0.58^{* * *} \\
(0.01)\end{array}$ & $\begin{array}{c}0.23^{* * *} \\
(0.01)\end{array}$ & $\begin{array}{c}0.50^{* * *} \\
(0.03)\end{array}$ & $\begin{array}{c}0.17^{* * *} \\
(0.06)\end{array}$ & $\begin{array}{c}0.77^{* * *} \\
(0.02)\end{array}$ & $\begin{array}{c}0.39^{* * *} \\
(0.02)\end{array}$ \\
\hline Obse & 848198 & 848072 & 848198 & 848072 & 110007 & 109990 & 110007 & 109990 \\
\hline Adjusted $R^{2}$ & 0.434 & 0.547 & 0.409 & 0.559 & 0.629 & 0.257 & 0.536 & 0.664 \\
\hline Fixed Effects & Time & Firm & Time & Firm & Time & Firm & Time & Firm \\
\hline Weighting & VW & VW & EW & EW & VW & VW & EW & EW \\
\hline Sample & All Firms & All Firms & All Firms & All Firms & Banks & Banks & Banks & Banks \\
\hline
\end{tabular}


Table A.6: Cost of Capital Estimates for Banks with Alternative Regulatory Breaks

This table reports the differential cost of capital for banks over time relative to other industries by regressing the CAPM expected return in annualized percentage units onto a constant and time period dummies along with indicator and interaction terms for banks. This table combines the Crisis and SCAP time periods to create one dummy for both periods. Standard errors are clustered by firm and month with ${ }^{*},{ }^{* *},{ }^{* * *}$ indicating significance at the $10 \%, 5 \%$, and $1 \%$ levels.

\begin{tabular}{|c|c|c|c|c|c|c|c|c|}
\hline & $\begin{array}{c}(1) \\
\text { CAPM - Rf }\end{array}$ & $\begin{array}{c}(2) \\
\text { CAPM - Rf }\end{array}$ & $\begin{array}{c}(3) \\
\text { CAPM - Rf }\end{array}$ & $\begin{array}{c}(4) \\
\text { CAPM - Rf }\end{array}$ & $\begin{array}{c}(5) \\
\text { CAPM - Rf }\end{array}$ & $\begin{array}{c}(6) \\
\text { CAPM - Rf }\end{array}$ & $\begin{array}{c}(7) \\
\text { CAPM - Rf }\end{array}$ & $\begin{array}{c}(8) \\
\text { CAPM - Rf }\end{array}$ \\
\hline GLB & $\begin{array}{l}-0.10 \\
(0.20)\end{array}$ & $\begin{array}{c}-0.82^{* * *} \\
(0.20)\end{array}$ & $\begin{array}{c}-1.72^{* * *} \\
(0.44)\end{array}$ & $\begin{array}{c}0.83^{* * *} \\
(0.20)\end{array}$ & $\begin{array}{c}1.54^{* * *} \\
(0.23)\end{array}$ & $\begin{array}{c}0.66^{* * *} \\
(0.19)\end{array}$ & $\begin{array}{l}-0.25 \\
(0.27)\end{array}$ & $\begin{array}{c}0.91^{* * *} \\
(0.21)\end{array}$ \\
\hline Crisis & $\begin{array}{l}-0.32 \\
(0.22)\end{array}$ & $\begin{array}{c}-0.89^{* * *} \\
(0.26)\end{array}$ & $\begin{array}{c}1.40^{* * *} \\
(0.47)\end{array}$ & $\begin{array}{c}1.46^{* * *} \\
(0.18)\end{array}$ & $\begin{array}{c}0.85^{* * *} \\
(0.24)\end{array}$ & $\begin{array}{c}0.11 \\
(0.24)\end{array}$ & $\begin{array}{c}1.44^{* * *} \\
(0.44)\end{array}$ & $\begin{array}{c}1.48^{* * *} \\
(0.19)\end{array}$ \\
\hline Dodd-Frank & $\begin{array}{l}-0.26 \\
(0.22)\end{array}$ & $\begin{array}{c}-0.99^{* * *} \\
(0.24)\end{array}$ & $\begin{array}{l}-0.05 \\
(0.43)\end{array}$ & $\begin{array}{c}2.12^{* * *} \\
(0.16)\end{array}$ & $\begin{array}{c}1.22^{* * *} \\
(0.22)\end{array}$ & $\begin{array}{c}0.35 \\
(0.23)\end{array}$ & $\begin{array}{c}0.61^{*} \\
(0.34)\end{array}$ & $\begin{array}{c}2.23^{* * *} \\
(0.18)\end{array}$ \\
\hline Bank & $\begin{array}{l}0.65^{*} \\
(0.37)\end{array}$ & $\begin{array}{c}-2.94^{* * *} \\
(0.43)\end{array}$ & $\begin{array}{c}-2.98^{* * *} \\
(0.48)\end{array}$ & $\begin{array}{c}-2.26^{* * *} \\
(0.54)\end{array}$ & $\begin{array}{c}-1.20^{* * *} \\
(0.40)\end{array}$ & $\begin{array}{c}-2.78^{* * *} \\
(0.52)\end{array}$ & $\begin{array}{c}-2.95^{* * *} \\
(0.51)\end{array}$ & $\begin{array}{c}-1.76^{* * *} \\
(0.56)\end{array}$ \\
\hline Bank x GLB & $\begin{array}{c}-1.04^{* *} \\
(0.43)\end{array}$ & $\begin{array}{l}-0.61 \\
(0.41)\end{array}$ & $\begin{array}{c}0.30 \\
(0.56)\end{array}$ & $\begin{array}{c}0.34 \\
(0.24)\end{array}$ & $\begin{array}{l}-0.92^{*} \\
(0.50)\end{array}$ & $\begin{array}{l}-0.01 \\
(0.36)\end{array}$ & $\begin{array}{l}0.90^{* *} \\
(0.39)\end{array}$ & $\begin{array}{l}0.42^{*} \\
(0.24)\end{array}$ \\
\hline Bank $\mathrm{x}$ Crisis & $\begin{array}{c}4.50^{* * *} \\
(0.61)\end{array}$ & $\begin{array}{c}4.84^{* * *} \\
(0.67)\end{array}$ & $\begin{array}{c}2.56^{* * *} \\
(0.64)\end{array}$ & $\begin{array}{c}2.40^{* * *} \\
(0.30)\end{array}$ & $\begin{array}{c}2.68^{* * *} \\
(0.59)\end{array}$ & $\begin{array}{c}3.93^{* * *} \\
(0.54)\end{array}$ & $\begin{array}{c}2.62^{* * *} \\
(0.61)\end{array}$ & $\begin{array}{c}2.41^{* * *} \\
(0.30)\end{array}$ \\
\hline Bank x Dodd-Frank & $\begin{array}{c}1.90^{* * *} \\
(0.45)\end{array}$ & $\begin{array}{c}2.40^{* * *} \\
(0.52)\end{array}$ & $\begin{array}{l}1.46^{* *} \\
(0.60)\end{array}$ & $\begin{array}{c}1.75^{* * *} \\
(0.27)\end{array}$ & $\begin{array}{c}1.69^{* * *} \\
(0.46)\end{array}$ & $\begin{array}{c}3.22^{\text {*** }} \\
(0.39)\end{array}$ & $\begin{array}{c}3.00^{* * *} \\
(0.44)\end{array}$ & $\begin{array}{c}1.81^{* * *} \\
(0.27)\end{array}$ \\
\hline Top & & & & & $\begin{array}{c}0.46 \\
(0.31)\end{array}$ & $\begin{array}{c}1.24^{* * *} \\
(0.43)\end{array}$ & $\begin{array}{l}1.18^{*} \\
(0.64)\end{array}$ & $\begin{array}{c}1.08^{* * * *} \\
(0.26)\end{array}$ \\
\hline Bank x Top & & & & & $\begin{array}{c}3.17^{* * *} \\
(0.53)\end{array}$ & $\begin{array}{c}0.16 \\
(0.59)\end{array}$ & $\begin{array}{c}0.17 \\
(0.72)\end{array}$ & $\begin{array}{c}0.38 \\
(0.53)\end{array}$ \\
\hline Top x GLB & & & & & $\begin{array}{c}-2.55^{* * *} \\
(0.41)\end{array}$ & $\begin{array}{c}-2.18^{* * *} \\
(0.34)\end{array}$ & $\begin{array}{c}-2.73^{* * *} \\
(0.70)\end{array}$ & $\begin{array}{c}-1.23^{* * *} \\
(0.25)\end{array}$ \\
\hline Top x Crisis & & & & & $\begin{array}{c}-1.81^{* * *} \\
(0.39)\end{array}$ & $\begin{array}{c}-1.42^{* * *} \\
(0.40)\end{array}$ & $\begin{array}{c}0.59 \\
(0.69)\end{array}$ & $\begin{array}{l}-0.33 \\
(0.28)\end{array}$ \\
\hline Top x Dodd-Frank & & & & & $\begin{array}{c}-2.28^{* * *} \\
(0.36)\end{array}$ & $\begin{array}{c}-1.90^{* * *} \\
(0.37)\end{array}$ & $\begin{array}{l}-0.94 \\
(0.74)\end{array}$ & $\begin{array}{c}-1.42^{* * *} \\
(0.28)\end{array}$ \\
\hline Bank x Top x GLB & & & & & $\begin{array}{l}-0.54 \\
(0.71)\end{array}$ & $\begin{array}{l}-1.05^{*} \\
(0.55)\end{array}$ & $\begin{array}{l}-0.50 \\
(0.84)\end{array}$ & $\begin{array}{c}-2.37^{* * *} \\
(0.39)\end{array}$ \\
\hline Bank $\mathrm{x}$ Top $\mathrm{x}$ Crisis & & & & & $\begin{array}{l}1.74^{* *} \\
(0.84)\end{array}$ & $\begin{array}{c}0.85 \\
(0.82)\end{array}$ & $\begin{array}{l}-1.19 \\
(0.88)\end{array}$ & $\begin{array}{c}0.63 \\
(0.63)\end{array}$ \\
\hline Bank x Top x Dodd-Frank & & & & & $\begin{array}{l}-0.23 \\
(0.66)\end{array}$ & $\begin{array}{c}-1.28^{* *} \\
(0.62)\end{array}$ & $\begin{array}{c}-2.31^{* *} \\
(0.90)\end{array}$ & $\begin{array}{c}-1.88^{* * *} \\
(0.51)\end{array}$ \\
\hline Observations & 1111127 & 1111062 & 223432 & 1111062 & 1111127 & 1111062 & 223432 & 1111062 \\
\hline Adjusted $R^{2}$ & 0.038 & 0.541 & 0.567 & 0.534 & 0.092 & 0.551 & 0.594 & 0.535 \\
\hline Fixed Effects & No & Yes & Yes & Yes & No & Yes & Yes & Yes \\
\hline Weighting & VW & VW & VW & $\mathrm{EW}$ & VW & VW & VW & EW \\
\hline Sample & All Firms & All Firms & Banks+NBF & All Firms & All Firms & All Firms & Banks+NBF & All Firms \\
\hline
\end{tabular}


Table A.7: The Cost of Capital for Banks Controlling for Risk-Weighted Assets Components

This table reports the cost of capital for banks over time controlling for different components of risk-weighted assets. The panel includes bank-month observations for which the risk-weighted assets components are available from call reports and Y-9C filings. The results are reported for the CAPM risk premium in value-weighted regressions with firm fixed effects. Standard errors are clustered by firm and month with ${ }^{*},{ }^{* *},{ }^{* *}$ indicating significance at the 10\%,5\%, and 1\% levels. The sample period is March 1996 to December 2017.

\begin{tabular}{|c|c|c|c|c|c|c|c|}
\hline & $\begin{array}{c}(1) \\
\text { CAPM - Rf }\end{array}$ & $\begin{array}{c}(2) \\
\text { CAPM - Rf }\end{array}$ & $\begin{array}{c}(3) \\
\text { CAPM - Rf }\end{array}$ & $\begin{array}{c}(4) \\
\text { CAPM - Rf }\end{array}$ & $\begin{array}{c}(5) \\
\text { CAPM - Rf }\end{array}$ & $\begin{array}{c}(6) \\
\text { CAPM - Rf }\end{array}$ & $\begin{array}{c}(7) \\
\text { CAPM - Rf }\end{array}$ \\
\hline GLB & $\begin{array}{c}-1.49^{* * *} \\
(0.38)\end{array}$ & $\begin{array}{c}-1.49^{* * *} \\
(0.38)\end{array}$ & $\begin{array}{c}-1.43^{* * *} \\
(0.39)\end{array}$ & $\begin{array}{c}-1.47^{* * *} \\
(0.36)\end{array}$ & $\begin{array}{c}-1.47^{* * *} \\
(0.37)\end{array}$ & $\begin{array}{c}-1.48^{* * *} \\
(0.39)\end{array}$ & $\begin{array}{c}-1.88^{* * *} \\
(0.48)\end{array}$ \\
\hline Crisis & $\begin{array}{c}2.46^{* * *} \\
(0.58)\end{array}$ & $\begin{array}{c}2.32^{* * *} \\
(0.57)\end{array}$ & $\begin{array}{c}2.51^{* * *} \\
(0.58)\end{array}$ & $\begin{array}{c}2.48^{* * *} \\
(0.59)\end{array}$ & $\begin{array}{c}2.56^{* * *} \\
(0.55)\end{array}$ & $\begin{array}{c}2.47^{* * *} \\
(0.61)\end{array}$ & $\begin{array}{l}1.85^{* *} \\
(0.72)\end{array}$ \\
\hline SCAP & $\begin{array}{c}6.44^{* * *} \\
(0.93)\end{array}$ & $\begin{array}{c}6.56^{* * *} \\
(0.90)\end{array}$ & $\begin{array}{c}6.53^{* * *} \\
(0.97)\end{array}$ & $\begin{array}{c}6.46^{* * *} \\
(1.01)\end{array}$ & $\begin{array}{c}6.34^{* * *} \\
(0.95)\end{array}$ & $\begin{array}{c}6.45^{* * *} \\
(1.00)\end{array}$ & $\begin{array}{c}5.93^{* * *} \\
(0.99)\end{array}$ \\
\hline Dodd-Frank & $\begin{array}{c}1.53^{* * *} \\
(0.51)\end{array}$ & $\begin{array}{c}1.82^{* * *} \\
(0.44)\end{array}$ & $\begin{array}{c}1.64^{* * *} \\
(0.58)\end{array}$ & $\begin{array}{l}1.55^{* *} \\
(0.63)\end{array}$ & $\begin{array}{l}1.39^{* *} \\
(0.56)\end{array}$ & $\begin{array}{l}1.54^{* *} \\
(0.62)\end{array}$ & $\begin{array}{l}1.32^{* *} \\
(0.63)\end{array}$ \\
\hline Cash + FF + Sec. & & $\begin{array}{c}-0.05^{* * *} \\
(0.02)\end{array}$ & & & & & $\begin{array}{c}-0.15^{* * *} \\
(0.04)\end{array}$ \\
\hline Loans & & & $\begin{array}{c}0.01 \\
(0.01)\end{array}$ & & & & $\begin{array}{c}-0.10^{* * *} \\
(0.03)\end{array}$ \\
\hline Trading Assets & & & & $\begin{array}{l}-0.01 \\
(0.11)\end{array}$ & & & $\begin{array}{l}-0.06 \\
(0.12)\end{array}$ \\
\hline Commitments & & & & & $\begin{array}{l}-0.02 \\
(0.02)\end{array}$ & & $\begin{array}{l}-0.03^{*} \\
(0.02)\end{array}$ \\
\hline Derivatives & & & & & & $\begin{array}{l}-0.00 \\
(0.00)\end{array}$ & $\begin{array}{c}0.00 \\
(0.00)\end{array}$ \\
\hline Observations & 99728 & 99728 & 99728 & 99728 & 99728 & 99728 & 99728 \\
\hline Adjusted $R^{2}$ & 0.575 & 0.580 & 0.576 & 0.575 & 0.577 & 0.575 & 0.591 \\
\hline Fixed Effects & Yes & Yes & Yes & Yes & Yes & Yes & Yes \\
\hline Weighting & VW & VW & VW & VW & VW & VW & VW \\
\hline Sample & Banks & Banks & Banks & Banks & Banks & Banks & Banks \\
\hline
\end{tabular}




\section{Table A.8: The Cost of Capital for Top Banks Controlling for Characteristics}

This table reports the differential cost of capital for the largest banks over time relative to other banks while controlling for bank characteristics. The characteristic $\mathrm{x}$ Top interactions allow the largest banks to have a different loading on the characteristics than other banks. The panel includes bank-month observations for which characteristics are available from call reports and Y-9C filings. The results are reported for the CAPM risk premium in value-weighted regressions with firm fixed effects. The characteristic variables are z-scored for ease of interpretation. Standard errors are clustered by firm and month with ${ }^{*},{ }^{* *},{ }^{* * *}$ indicating significance at the $10 \%, 5 \%$, and $1 \%$ levels. The sample period is March 1996 to December 2017.

\begin{tabular}{|c|c|c|c|c|c|c|c|}
\hline & $\begin{array}{c}(1) \\
\text { CAPM - Rf }\end{array}$ & $\begin{array}{c}(2) \\
\text { CAPM - Rf }\end{array}$ & $\begin{array}{c}(3) \\
\text { CAPM - Rf }\end{array}$ & $\begin{array}{c}(4) \\
\text { CAPM - Rf }\end{array}$ & $\begin{array}{c}(5) \\
\text { CAPM - Rf }\end{array}$ & $\begin{array}{c}(6) \\
\text { CAPM - Rf }\end{array}$ & $\begin{array}{c}(7) \\
\text { CAPM - Rf }\end{array}$ \\
\hline GLB & $\begin{array}{l}0.78^{* *} \\
(0.36)\end{array}$ & $\begin{array}{l}0.80^{* *} \\
(0.36)\end{array}$ & $\begin{array}{l}0.69^{* *} \\
(0.35)\end{array}$ & $\begin{array}{l}0.71^{*} \\
(0.37)\end{array}$ & $\begin{array}{l}0.61^{*} \\
(0.36)\end{array}$ & $\begin{array}{l}0.74^{* *} \\
(0.36)\end{array}$ & $\begin{array}{c}0.49 \\
(0.35)\end{array}$ \\
\hline Crisis & $\begin{array}{c}3.94^{* * *} \\
(0.43)\end{array}$ & $\begin{array}{c}3.92^{* * *} \\
(0.42)\end{array}$ & $\begin{array}{c}3.88^{* * *} \\
(0.44)\end{array}$ & $\begin{array}{c}3.80^{* * *} \\
(0.40)\end{array}$ & $\begin{array}{c}3.79^{* * *} \\
(0.44)\end{array}$ & $\begin{array}{c}3.85^{* * *} \\
(0.44)\end{array}$ & $\begin{array}{c}3.55^{* * *} \\
(0.46)\end{array}$ \\
\hline SCAP & $\begin{array}{c}5.74^{* * *} \\
(0.62)\end{array}$ & $\begin{array}{c}5.79^{* * *} \\
(0.62)\end{array}$ & $\begin{array}{c}5.80^{* * *} \\
(0.62)\end{array}$ & $\begin{array}{c}5.85^{* * *} \\
(0.63)\end{array}$ & $\begin{array}{c}5.57^{* * *} \\
(0.61)\end{array}$ & $\begin{array}{c}5.68^{* * *} \\
(0.61)\end{array}$ & $\begin{array}{c}5.67^{* * *} \\
(0.59)\end{array}$ \\
\hline Dodd-Frank & $\begin{array}{c}3.84^{* * *} \\
(0.38)\end{array}$ & $\begin{array}{c}3.91^{* * *} \\
(0.39)\end{array}$ & $\begin{array}{c}3.90^{* * *} \\
(0.39)\end{array}$ & $\begin{array}{c}4.08^{* * *} \\
(0.40)\end{array}$ & $\begin{array}{c}3.74^{* * * *} \\
(0.39)\end{array}$ & $\begin{array}{c}3.78^{* * *} \\
(0.38)\end{array}$ & $\begin{array}{c}4.01^{* * *} \\
(0.38)\end{array}$ \\
\hline Top x GLB & $\begin{array}{c}-3.36^{* * *} \\
(0.50)\end{array}$ & $\begin{array}{c}-3.40^{* * *} \\
(0.52)\end{array}$ & $\begin{array}{c}-3.25^{* * *} \\
(0.48)\end{array}$ & $\begin{array}{c}-3.31^{* * *} \\
(0.51)\end{array}$ & $\begin{array}{c}-3.17^{* * *} \\
(0.49)\end{array}$ & $\begin{array}{c}-3.26^{* * *} \\
(0.49)\end{array}$ & $\begin{array}{c}-2.94^{* * *} \\
(0.47)\end{array}$ \\
\hline Top x Crisis & $\begin{array}{c}-2.25^{* * *} \\
(0.61)\end{array}$ & $\begin{array}{c}-2.25^{* * * *} \\
(0.62)\end{array}$ & $\begin{array}{c}-2.20^{* * *} \\
(0.62)\end{array}$ & $\begin{array}{c}-2.16^{* * *} \\
(0.61)\end{array}$ & $\begin{array}{c}-2.10^{* * *} \\
(0.65)\end{array}$ & $\begin{array}{c}-2.08^{* * *} \\
(0.60)\end{array}$ & $\begin{array}{c}-1.86^{* * *} \\
(0.62)\end{array}$ \\
\hline Top x SCAP & $\begin{array}{c}0.28 \\
(0.98)\end{array}$ & $\begin{array}{c}0.07 \\
(0.99)\end{array}$ & $\begin{array}{c}0.30 \\
(0.99)\end{array}$ & $\begin{array}{c}0.35 \\
(0.96)\end{array}$ & $\begin{array}{c}0.45 \\
(1.00)\end{array}$ & $\begin{array}{c}0.47 \\
(0.93)\end{array}$ & $\begin{array}{c}0.53 \\
(0.91)\end{array}$ \\
\hline Top x Dodd-Frank & $\begin{array}{c}-3.26^{* * * *} \\
(0.62)\end{array}$ & $\begin{array}{c}-3.57^{* * * *} \\
(0.72)\end{array}$ & $\begin{array}{c}-3.13^{* * *} \\
(0.64)\end{array}$ & $\begin{array}{c}-3.19^{* * *} \\
(0.59)\end{array}$ & $\begin{array}{c}-3.15^{* * *} \\
(0.64)\end{array}$ & $\begin{array}{c}-3.00^{* * *} \\
(0.62)\end{array}$ & $\begin{array}{c}-3.11^{* * *} \\
(0.63)\end{array}$ \\
\hline Tier 1 Ratio & & $\begin{array}{l}-0.04 \\
(0.06)\end{array}$ & & & & & $\begin{array}{l}-0.04 \\
(0.05)\end{array}$ \\
\hline Tier 1 Ratio x Top & & $\begin{array}{c}0.10 \\
(0.10)\end{array}$ & & & & & $\begin{array}{l}0.19^{*} \\
(0.11)\end{array}$ \\
\hline Core Deposits & & & $\begin{array}{l}-0.02^{*} \\
(0.01)\end{array}$ & & & & $\begin{array}{l}-0.00 \\
(0.01)\end{array}$ \\
\hline Core Deposits x Top & & & $\begin{array}{l}-0.00 \\
(0.02)\end{array}$ & & & & $\begin{array}{l}-0.04 \\
(0.03)\end{array}$ \\
\hline Liq. Coverage & & & & $\begin{array}{c}-0.04^{* * *} \\
(0.01)\end{array}$ & & & $\begin{array}{c}-0.04^{* * *} \\
(0.01)\end{array}$ \\
\hline Liq. Coverage x Top & & & & $\begin{array}{c}0.02 \\
(0.02)\end{array}$ & & & $\begin{array}{c}0.02 \\
(0.02)\end{array}$ \\
\hline Non Int. Inc. & & & & & $\begin{array}{l}0.02^{*} \\
(0.01)\end{array}$ & & $\begin{array}{l}0.03^{*} \\
(0.01)\end{array}$ \\
\hline Non Int. Inc. x Top & & & & & $\begin{array}{l}-0.03^{*} \\
(0.01)\end{array}$ & & $\begin{array}{l}-0.04^{* *} \\
(0.02)\end{array}$ \\
\hline RWA & & & & & & $\begin{array}{c}0.01 \\
(0.01)\end{array}$ & $\begin{array}{c}0.00 \\
(0.02)\end{array}$ \\
\hline RWA x Top & & & & & & $\begin{array}{c}0.01 \\
(0.02)\end{array}$ & $\begin{array}{c}0.03 \\
(0.02)\end{array}$ \\
\hline Top & $\begin{array}{l}1.20^{* *} \\
(0.48)\end{array}$ & $\begin{array}{c}0.14 \\
(1.04)\end{array}$ & $\begin{array}{c}1.37 \\
(1.11)\end{array}$ & $\begin{array}{c}0.03 \\
(1.05)\end{array}$ & $\begin{array}{c}2.47^{* * *} \\
(0.90)\end{array}$ & $\begin{array}{c}0.61 \\
(1.29)\end{array}$ & $\begin{array}{l}-1.08 \\
(2.24)\end{array}$ \\
\hline Observations & 99728 & 99728 & 99728 & 99728 & 99728 & 99728 & 99728 \\
\hline Adjusted $R^{2}$ & 0.602 & 0.602 & 0.603 & 0.605 & 0.602 & 0.602 & 0.610 \\
\hline Fixed Effects & Yes & Yes & Yes & Yes & Yes & Yes & Yes \\
\hline Weighting & VW & VW & VW & VW & VW & VW & VW \\
\hline Sample & Banks & Banks & Banks & Banks & Banks & Banks & Banks \\
\hline
\end{tabular}


Figure A.1: Banks vs. Non-Banks Parallel Trend Analysis
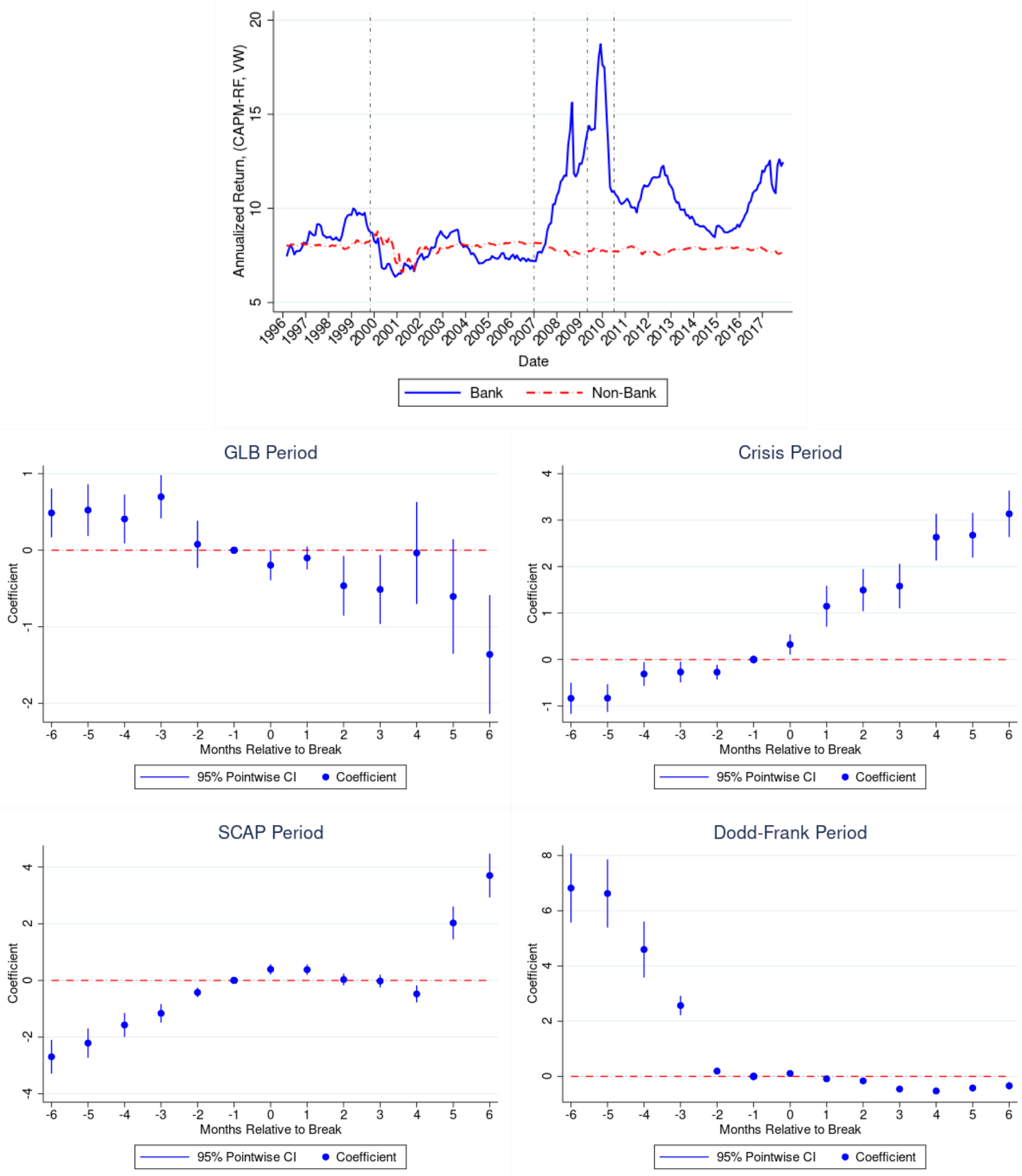

The top figure plots the value-weighted CAPM risk premium for banks and non-banks from 1996 to 2017. The bottom figure plots the differential cost of capital for banks in a six-month window around the regulatory time period breaks by reporting Bank x time period interaction coefficients along with $95 \%$ pointwise confidence intervals relative to the month before the period starts. 
Figure A.2: Banks vs. Non-Bank Financials Parallel Trend Analysis
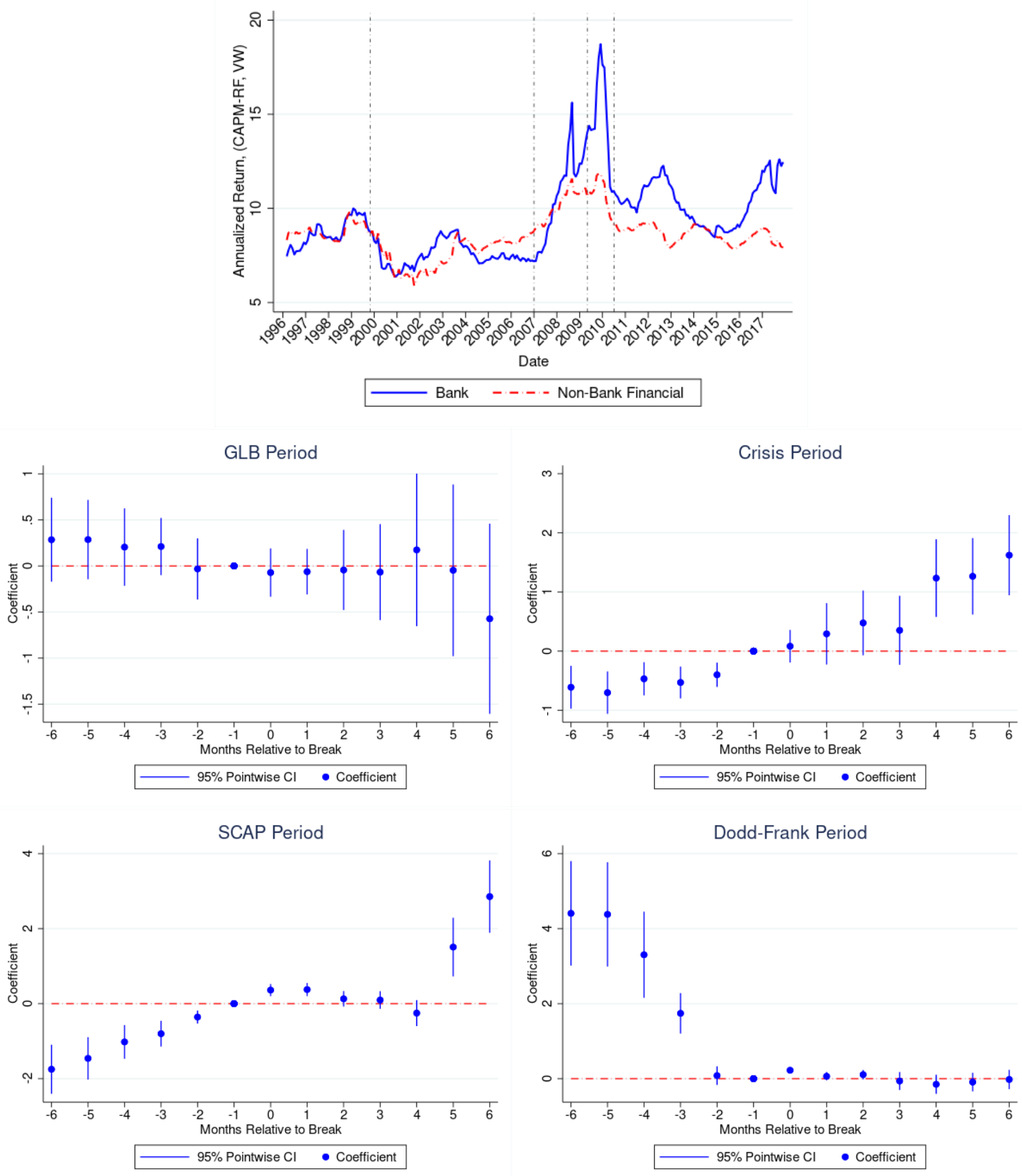

The top figure plots the value-weighted CAPM risk premium for banks and non-bank financials from 1996 to 2017. The bottom figure plots the differential cost of capital for banks in a six-month window around the regulatory time period breaks by reporting Bank $\mathrm{x}$ time period interaction coefficients along with $95 \%$ pointwise confidence intervals relative to the month before the period starts. 
Figure A.3: Parallel Trend Analysis around March 2010 for Potential Anticipation Effects Before the Dodd-Frank Period

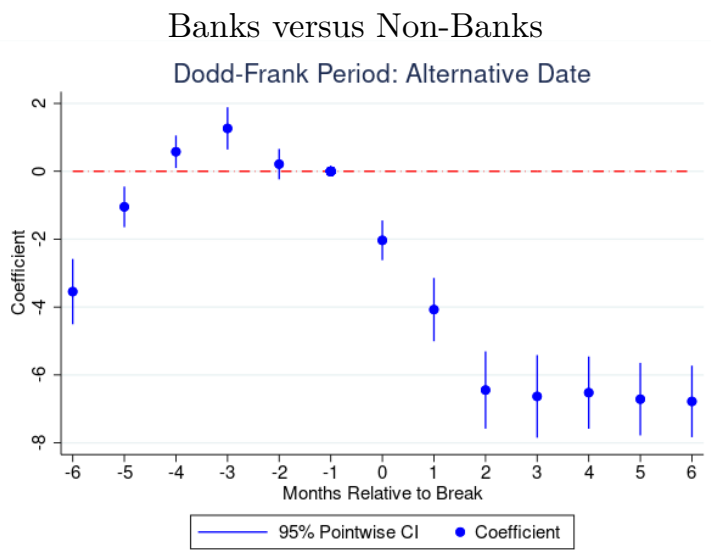

Banks versus Non-Bank Financials

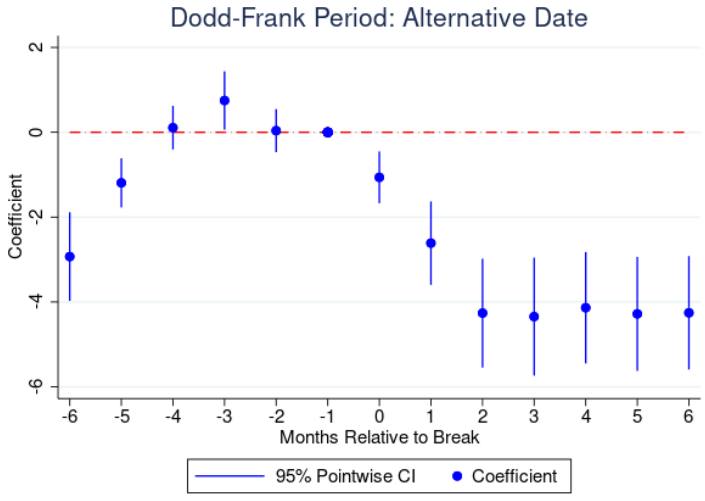

These figures consider the potential for anticipation effects around the Dodd-Frank Act by plotting the differential cost of capital for the different comparison groups in a six-month window around March 2010, rather than July 2010 when the legislation was passed. The plots are analogous to Figures A1 to A2 for the Dodd-Frank period except for changing the start date of the period. 